DE82 015082

\title{
Hot-Dry-Rock Geothermal Resource 1980
}

\author{
Edited by \\ Grant Heiken \\ Fraser Goff \\ Glenda Cremer
}

\section{Contributors}

M. J. Aldrich Barbara Arney Mark E. Ander Andrea C. Eddy Fraser Goff
Grant Heiken Andrea Kron Carol LaDelfe

A. W. Laughlin J. E. Maxwell

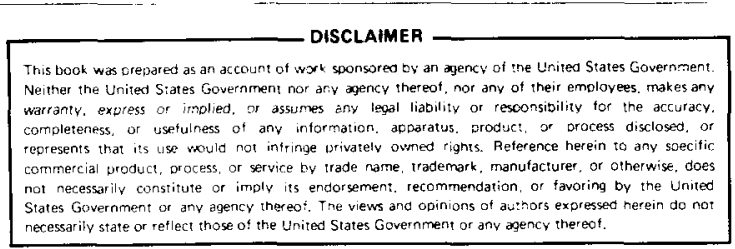




\section{DISCLAIMER}

This report was prepared as an account of work sponsored by an agency of the United States Government. Neither the United States Government nor any agency Thereof, nor any of their employees, makes any warranty, express or implied, or assumes any legal liability or responsibility for the accuracy, completeness, or usefulness of any information, apparatus, product, or process disclosed, or represents that its use would not infringe privately owned rights. Reference herein to any specific commercial product, process, or service by trade name, trademark, manufacturer, or otherwise does not necessarily constitute or imply its endorsement, recommendation, or favoring by the United States Government or any agency thereof. The views and opinions of authors expressed herein do not necessarily state or reflect those of the United States Government or any agency thereof. 


\section{DISCLAIMER}

Portions of this document may be illegible in electronic image products. Images are produced from the best available original document. 
CONTENTS

page

ABSTRACT

I. INTRODUCTION 1

II. FAR WEST: REGIONAL AND SITE-SPECIFIC EVALUATIONS FOR CALIFORNIA, NEVADA, AND UTAH

III. PACIFIC NORTHWEST: REGIONAL AND SITE-SPECIFIC EVALUATIONS 27

IV. SOUTHWEST: HEAT SOURCES IN ARIZONA, NEW MEXICO, AND THE TRANSPECOS AREA OF TEXAS

V. HDR GEOTHERMAL POTENTIAL IN THE ROCKY MOUNTAIN STATES OF COLORADO, WYOMING, AND MONTANA

55

VI. MIDCONTINENT REGION: EVALUATION OF THE HDR RESOURCES 67

VII. EASTERN REGION: HDR RESOURCE ASSESSMENT

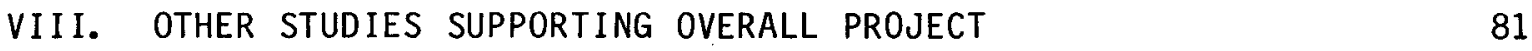

IX. PRELIMINARY ESTIMATE OF RESOURCE BASE 93

$\begin{array}{lr}\text { ACKNOWLEDGMENTS } & 94\end{array}$

$\begin{array}{lr}\text { REFERENCES } & 99\end{array}$ 
HOT DRY ROCK GEOTHERMAL RESOURCE

1980

Edited by

Grant Heiken, Fraser Goff, and Glenda Cremer

\section{ABSTRACT}

This report summarizes the work performed during 1980 by the LoS Alamos National Laboratory and its subcontractors on hot dry rock (HDR) geothermal resource evaluation, site characterization, and geophysical exploration techniques. The work was done by region (Far West, Pacific Northwest, Southwest, Rocky Mountain States, Midcontinent, and Eastern) and limited to the conterminous U.S.

\section{INTRODUCTION (G. Heiken and Fraser Goff)}

After the hot dry rock (HDR) geothermal experiments at Fenton Hill, New Mexico, proved that energy extraction from hot rock of the earth's crust was technically feasible, the Department of Energy (DOE) expanded the program to include evaluation of the HDR geothermal resource of the U.S. The Fenton Hill project is based on a concept developed at Los Alamos National Laboratory, which involves a closed, man-made geothermal system. Simply stated: Two well bores, drilled into hot rock of very low permeability, are connected by a man-made fracture system; cool water, pumped down one well bore, is heated as it flows through the fracture system and returns as hot water up the other well bore to the surface.

It has been estimated that if only $1 \%$ of the U.S. HDR resource base to a 7-km depth in the earth's crust could be recovered as heat energy, it could supply our current nontransportation needs (HDR Program Plan 1980). One of the first steps necessary to evaluate the HDR geothermal resource of the U.S. is to confirm its size, distribution, and accessibility, and to identify and 
characterize it. Therefore, in cooperation with the United States Geological Survey (USGS) and other research institutions, LOS Alamos National Laboratory began a program with a two-pronged objective:

1. gather and analyze existing geologic and geophysical data and acquire new data necessary to identify and characterize the HDR resource base, and

2. identify and characterize candidates for HDR Site 2, in order to demonstrate that HDR technology can be applied throughout the U.S.

This report offers a summary of our work for 1980 .

An earlier evaluation (Hot Dry Rock Assessment Panel 1977) concentrated mainly on young volcanic fields. This summary covers not only these high-grade areas within igneous systems but also those broad regions having elevated thermal gradients but no volcanism or hydrothermal activity. To demonstrate that HDR is a viable energy resource, we must identify and characterize regions where thermal gradients are $>30^{\circ} \mathrm{C} / \mathrm{km}$. These gradients create temperatures that are suitable for direct use (heat) and are broadly distributed throughout the U.S. The exceptions are the deep sedimentary basins, especially in the Gulf Coastal Plains where great depths to rock units with limited permeability preclude HDR energy extraction. This area is not included in our evaluation. Also, our activities are limited to the conterminous U.S.

\section{A. Requirements and Criteria}

The basic requirement for HDR reservoirs is hot, low-permeability rocks at relatively shallow depths (high-grade areas). For wells used to generate electricity, our present technology requires temperatures of at least $150^{\circ} \mathrm{C}$, at depths of $\leq 6 \mathrm{~km}$ in any scale units with low permeability, amiable to hydraulic fracturing. For practical purposes, these limits are realistically $\geq 200^{\circ} \mathrm{C}$ and $\leq 5 \mathrm{~km}$. It is also preferable that these rocks occur in masses that are not severely fractured or faulted. We anticipate, however, that technologies can be developed for using a variety of rocks having limited permeability, occurring in a variety of seismic and tectonic regimes.

The major criteria used to assess a site's HDR potential are

1. distribution and depth to appropriate reservoir rocks,

2. distribution of Quaternary volcanic centers,

3. distribution of active hydrothermal systems,

4. earth crustal thickness, and

5. regional heat flow and thermal gradients. 
Other factors such as measurements of temperature, gravity, and magnetic and electrical fields are considered when they are relevant.

B. Definitions

HDR Resource Base: A11 thermal energy $>15^{\circ} \mathrm{C}$ available in regions having thermal gradients $>30^{\circ} \mathrm{C} / \mathrm{km}$, which are not part of a hydrothermal or geopressured system.

Accessible Resource Base: The thermal energy available at $>90^{\circ} \mathrm{C}$ (for direct use) or $>150^{\circ} \mathrm{C}$ (for generation of electricity) to a depth of $6 \mathrm{~km}$, which may be extracted using HDR techniques without regard to cost.

Economically Recoverable Resource: That part of the accessible resource base that may be extracted economically considering drilling costs, environment, and demography. (Defined as the useful accessible resource base, or resource in USGS Circular 790, Muffler 1979).

C. Report Organization

To facilitate our evaluation, we divided the work among Los Alamos personnel and subcontractors according to region (Fig. 1). During 1980 this work consisted mostly of gathering and analyzing data from the literature,

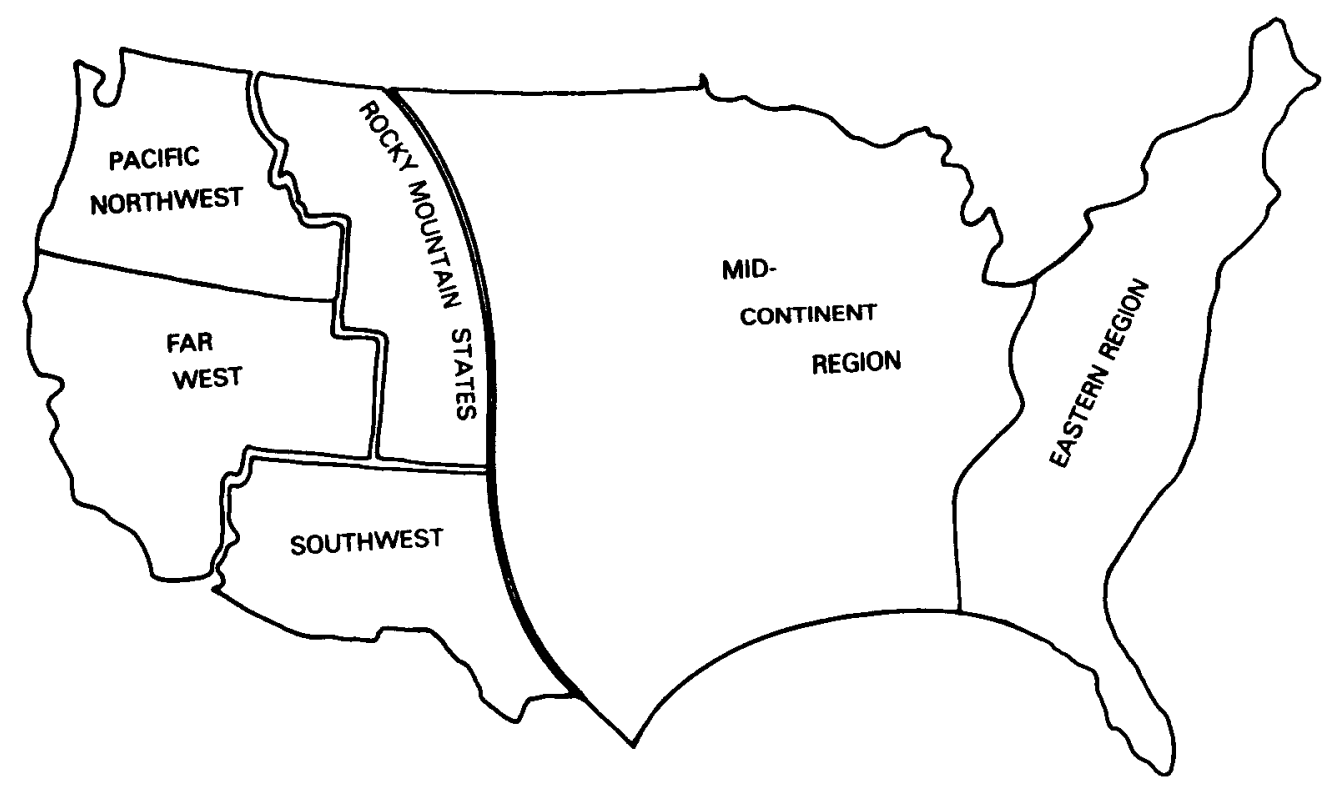

Fig. 1. Regions established for evaluation of the hot dry rock geothermal resource. 
al though some new heat-flow measurements were made. Our primary goal was to identify thermal anomalies within each region and to characterize the geologic setting of those anomalies. In addition, site characterization of highgrade prospects is discussed because of their potential candidacy for an HDR Site 2.

In addition to the regional evaluations, there are several on-going studies. Section VIII reports on these projects, which include magnetotelluric surveys in New Mexico and Arizona; preparation of a conductive geothermal map of the conterminous U.S.; and examination of a variety of igneous sytems.

The final section offers a revised estimate of the HDR Resource Base and includes a table estimating the HDR resource base by region and a table summarizing the geophysics and geology of the various regions at the end of 1980 . 
II. FAR WEST: REGIONAL AND SITE-SPECIFIC EVALUATIONS FOR CALIFORNIA, NEVADA, AND UTAH (Fraser Goff and Andrea Kron)

California, Nevada, and Utah offer many of the best prospects for HDR geothermal energy because of the presence of several large Quaternary volcanic systems and the vast regional thermal anomalies in the northern Basin and Range province. This section discusses the HDR potential of five major physiographic tectonic provinces within these states (Fig. 2), with respect to regional geologic and geophysical characteristics. The HDR potential of four hightemperature, magma-hydrothermal systems, where hydrothermal systems are currently being explored or exploited, is also reviewed.

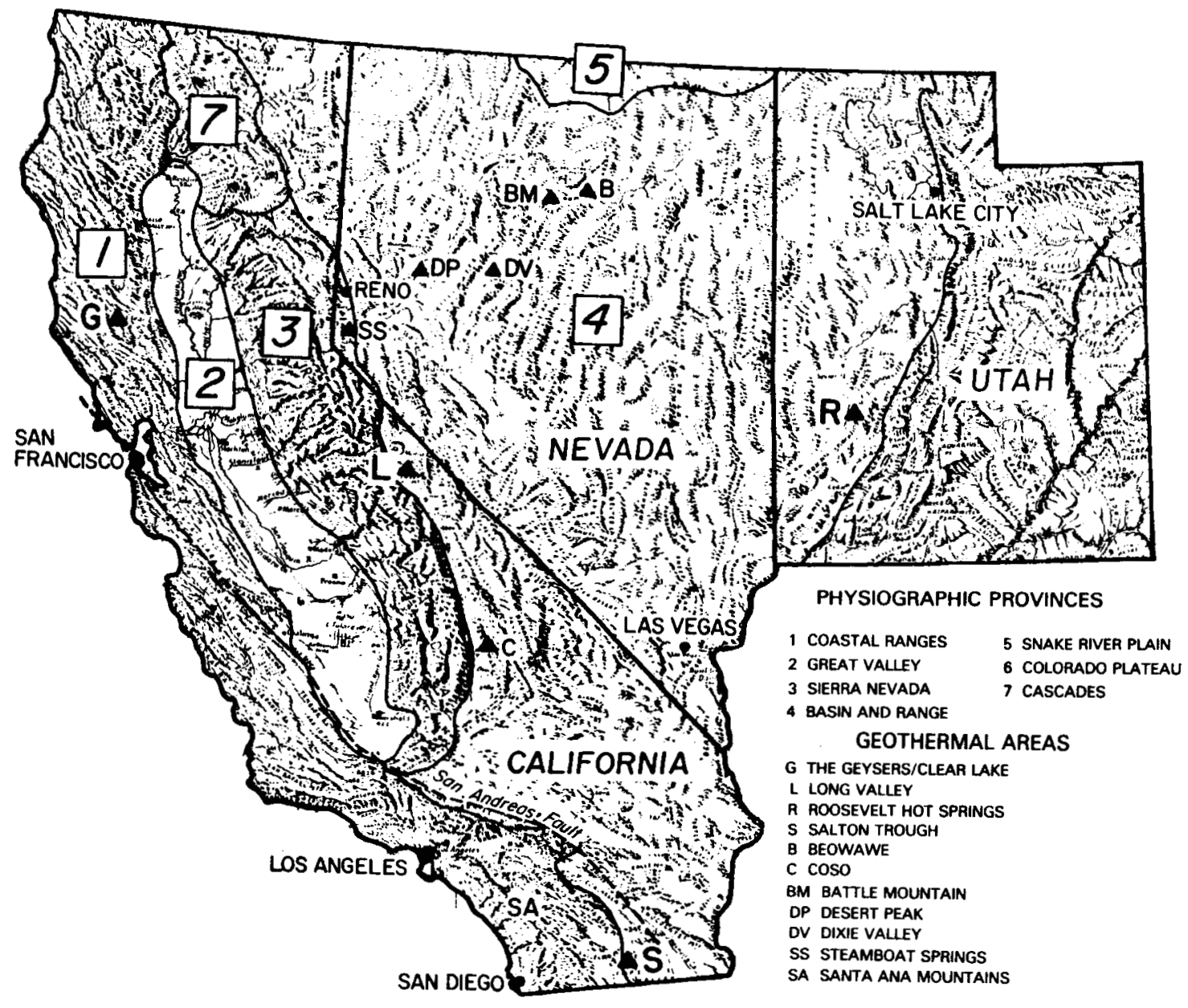

Fig. 2. Physiographic provinces, major geothermal targets and the San Andreas fault zone of the Far West region. 
As a preliminary assessment of the regional HDR potential of the Far West, we compiled data on the five criteria listed in the Introduction (see Figs. 3 and 4 and Table I). We also considered the regional distribution of seismic activity because of its possible influence on reservior development, and depth to reservoir rocks because of its economic significance. Additional geophysical criteria such as gravity and electrical resistivity were evaluated only at high-grade sites, even though these data have been useful as regional HDR exploration tools in the eastern U.S. and Arizona (see Sec. IV by J. Aldrich and A. W. Laughlin and Sec. VII by J. Maxwe11).

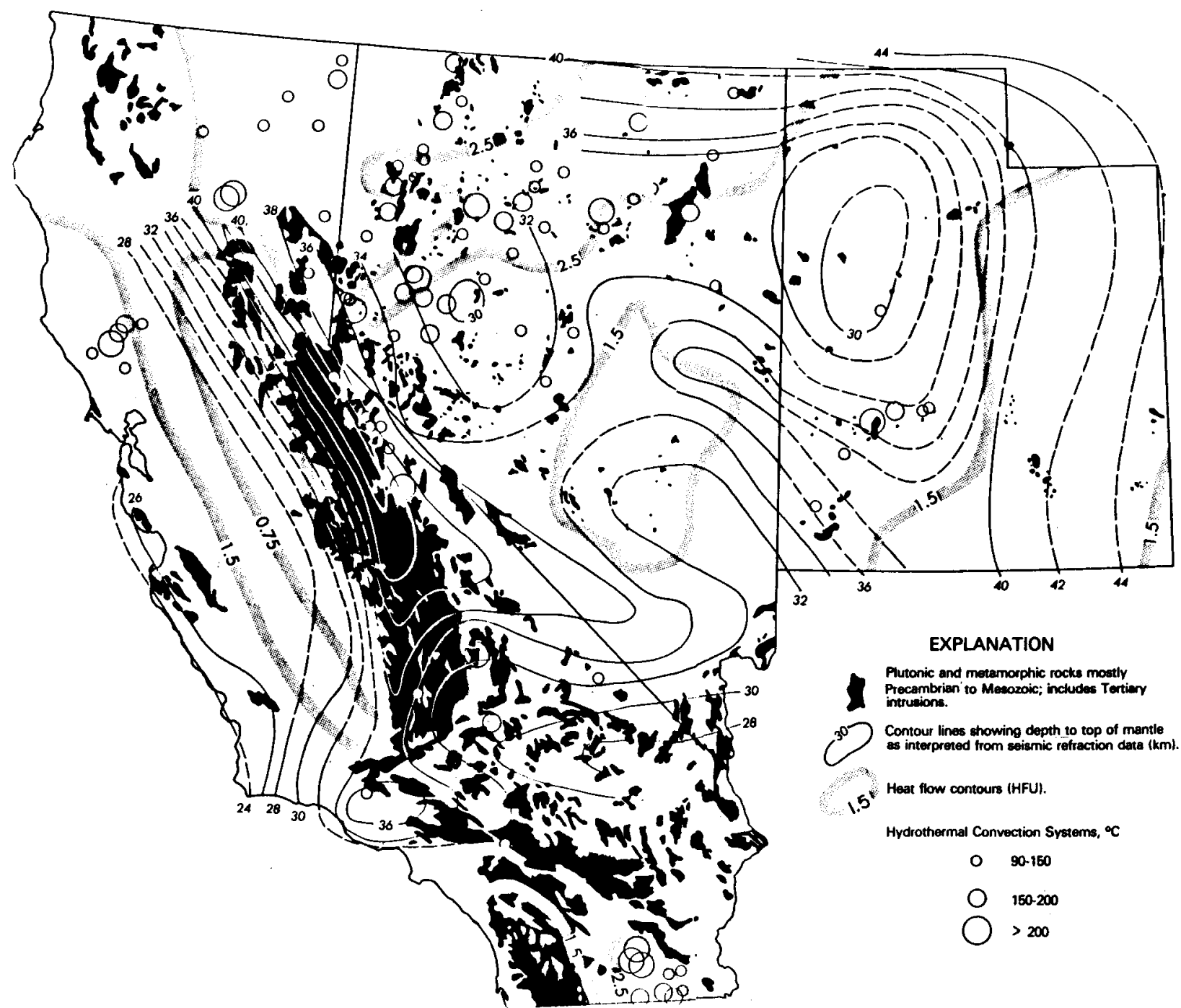

Fig. 3. Heat flow, crustal thicknes, hydrothermal convection systems, and outcrops of plutonic and metamorphic rocks for California, Nevada, and Utah. (Sass et al. 1980; Prodeh1 1979; Brook et al. 1979; Jennings 1977; Stewart and Car1son 1976; and USGS and AAPG 1962). 


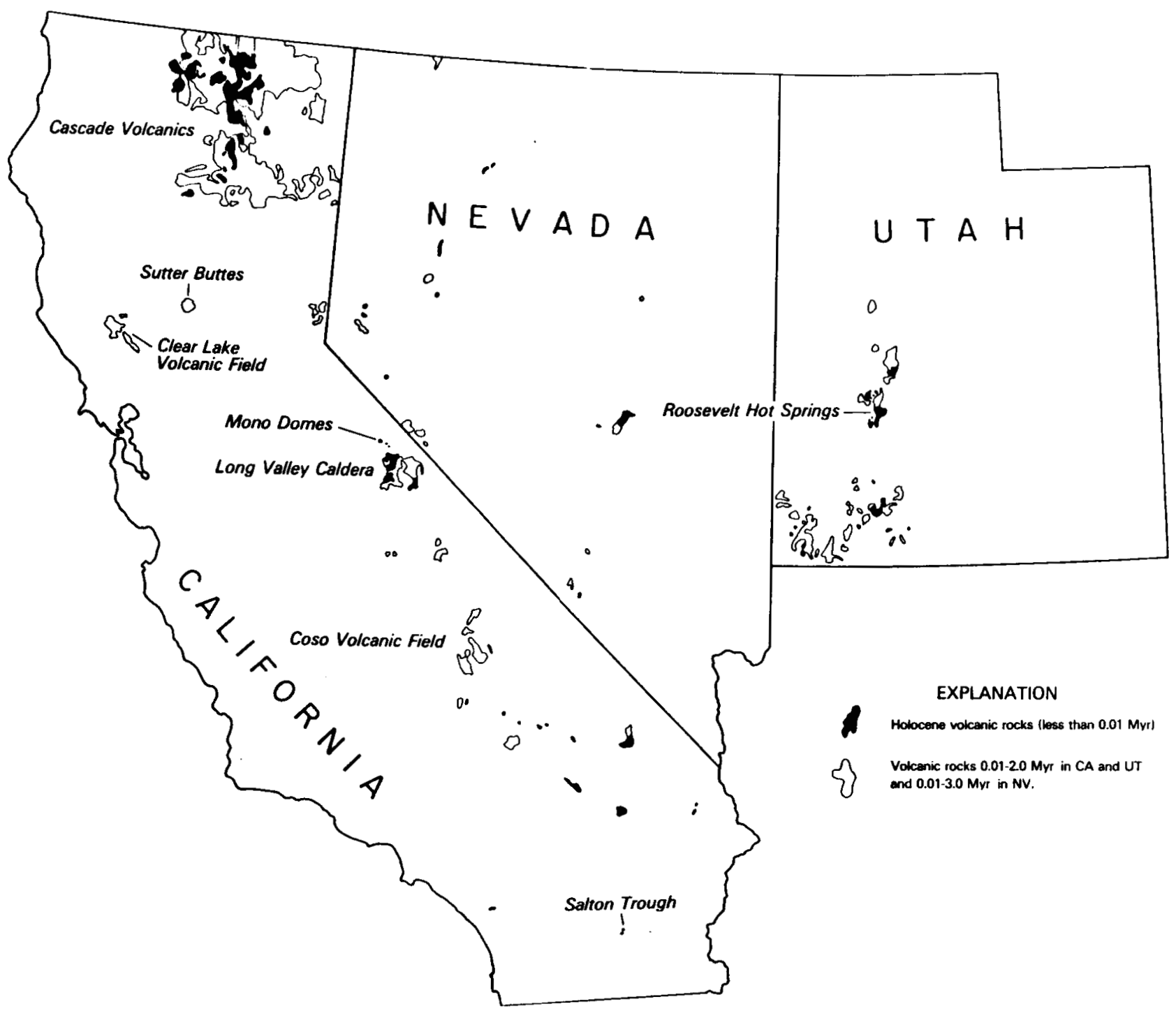

Fig. 4. Location of Quaternary volcanic rocks in California, Nevada, and Utah (Willden 1964; Roberts et al. 1967; Bonham 1969; Moore 1969; Willden and Speed 1974; Luedke and Smith 1978a; Jennings 1977; Stewart and Carlson 1976; Silberman and McKee 1972, and Vaniman et al. 1980.

F. General Geology and Geophysics of the Region

Of the seven physiographic/tectonic provinces in California, Nevada, and Utah (Fig. 2), five are discussed below. The remaining two, Cascade and Snake River Plain provinces, occur mainly in the northwest and are covered by $B$. $H$. Arney in Sec. III.

1. California Coast Ranges. Complicated structure, active transform tectonics, low-to-moderate regional thermal gradients, and extensive marine sedimentary sequences of unknown permeability preclude most of the Coast Ranges 


\section{TABLE I}

GEOLOGIC AND GEOPHYSICAL DATA USED TO EVALUATE HDR GEOTHERMAL POTENTIAL OF FIVE PHYSIOGRAPHIC PROVINCES IN CALIFORNIA-NEVADA-UTAH

\begin{tabular}{|c|c|c|c|c|c|c|c|c|c|}
\hline & & General & eophysical & aracteristi & & & & Quaternary Magna-Hydrothe & 1 Systems \\
\hline & $\begin{array}{l}\text { Crustal } \\
\text { Thickness, } \\
\mathrm{km}\end{array}$ & $\begin{array}{l}\text { Heat } \\
\text { Flow, } \\
\text { HFU }\end{array}$ & $\begin{array}{l}\text { Thermal } \\
\text { Gradtent, } \\
{ }_{0} \mathrm{C} / \mathrm{km}\end{array}$ & $\begin{array}{l}\text { Depth to } \\
200^{\circ} \mathrm{c}, \\
\mathrm{km}\end{array}$ & Tectonics and Seismicity & $\begin{array}{l}\text { Possible HOR } \\
\text { Reservotr Rocks }\end{array}$ & site & Volcanism & Geotheraal fluids \\
\hline Coast Ranges & $24-28$ & .2 .0 & $25-35$ & 6 & $\begin{array}{l}\text { San Andreas transform } \\
\text { zone : act ive tectorics } \\
\text { and high sei smicity. }\end{array}$ & $\begin{array}{l}\text { 1. Jurassic-Eocene meta- } \\
\text { sediments } \\
\text { 2. Mesozotc plutonic }\end{array}$ & $\begin{array}{l}\text { 1. Geysers- } \\
\text { Clear Lake }\end{array}$ & $\begin{array}{l}\text { Silicic volcanic fteld, } \\
\text { mostly dacite and basalit; age } \\
2-0.01 \text { Wyr. }\end{array}$ & $\begin{array}{l}\text { Vapor-dominnated zone at The Geysers, } \\
T_{1}=240^{\circ} \mathrm{C} \text {; Hot water at zones to } \\
\text { northeast, T } \leq 250^{\circ} \mathrm{C} \text {. }\end{array}$ \\
\hline & & & & & & & $\begin{array}{l}\text { 2. Salton } \\
\text { Trough }\end{array}$ & $\begin{array}{l}\text { Four rhyolite domes; age } \\
\text { S0.6 Myr. }\end{array}$ & $\begin{array}{l}\text { Many large hot water reservoirs, } \\
\tau \leq 350^{\circ} \mathrm{C} \text {. }\end{array}$ \\
\hline Central Val ley & $28-34$ & $\leq 1.0$ & 25 & $\$ 10$ & $\begin{array}{l}\text { Tectonically inactive; } \\
\text { low seismicity. }\end{array}$ & None identified & 1. Sutter Buttes & $\begin{array}{l}\text { Silicic volcanic field } \\
\text { mostly dacite and andesite; } \\
\text { age } 2-1.5 \text { Myr. }\end{array}$ & Mone known \\
\hline Sterra Mevada & $34-52$ & $1-2$ & $\leq 30$ & o6 & $\begin{array}{l}\text { Tectontcally and seis- } \\
\text { mically inactive except } \\
\text { along east and mest } \\
\text { margins. }\end{array}$ & Mesozolc Granite & 1. Long Valley & $\begin{array}{l}\text { Siltcic caldera with asso- } \\
\text { ctated rhyolite domes; age } \\
0.7 \text { kyr to } 450 \text { yr. }\end{array}$ & $\begin{array}{l}\text { Small hot water reservoir. } \\
\mathrm{T} \leq 180^{\circ} \mathrm{C} \text {. }\end{array}$ \\
\hline & & & & & & & $\begin{array}{l}\text { 2. Coso } \\
\text { Volcanic } \\
\text { Field }\end{array}$ & $\begin{array}{l}\text { Bimodal basalt-rhyolite suite; } \\
\text { age } 0.9-0.04 \text { Mrr. }\end{array}$ & $\begin{array}{l}\text { Small hot water reservoir. } \\
T=165^{\circ} \mathrm{C} .\end{array}$ \\
\hline & & & & & & & 3. Mono Domes & $\begin{array}{l}\text { At least } 10 \text { rhyol ite doanes and } \\
\text { assoclated pyroclastics; oge } \\
55000 \text { yrs. }\end{array}$ & $\begin{array}{l}\text { Mone knowm; a few hot springs in } \\
\text { area. }\end{array}$ \\
\hline Basin and Range & $28-36$ & $1.5-2.8$ & 240 & 4-5 & $\begin{array}{l}\text { Tectonically and seis- } \\
\text { mically active. }\end{array}$ & $\begin{array}{l}\text { Plutonic and metamorphis } \\
\text { rocks of vartious ages. }\end{array}$ & $\begin{array}{l}\text { 1. Roosevelt } \\
\text { Hot Springs }\end{array}$ & $\begin{array}{l}\text { Bimodal basalt-rhyol te suite; } \\
\text { age } 0.8-0.01 \text { Hyr. }\end{array}$ & $\begin{array}{l}\text { Moderate stze hot water reservoir. } \\
i \geq 260^{\circ} \mathrm{C} \text {. }\end{array}$ \\
\hline Colorado Plateau & $>40$ & $\ll 1.5$ & $\leq 25$ & 8 & $\begin{array}{l}\text { Moderate to low tec- } \\
\text { tonic and sei smic } \\
\text { activity. }\end{array}$ & $\begin{array}{l}\text { Precambrian piutonic } \\
\text { and metamorphic rocks }\end{array}$ & & & \\
\hline
\end{tabular}


area from consideration for HDR development using present techniques. The area does, however, contain three promising targets: The Geysers-Clear Lake region north of San Francisco, the Salton Trough on the southeast margin of the province, and the Santa Ana Mountains northeast of San Diego. These areas are discussed in detail later as high-grade HDR targets.

The Coast Ranges, as defined here, include the Transverse Ranges, Ventura and Los Angeles Basins, and the Southern California batholith. Geology consists mostly of Mesozoic to Tertiary marine sedimentary and volcanic rocks. Mesozoic plutonic and associated metamorphic rocks of the Salinian block comprise a major portion of the Santa Ana Mountains northeast of San Diego and occur in discontinuous fault-bounded masses west of the San Andreas fault zone northward to San Francisco. A series of Tertiary-Quaternary volcanic centers, which progressively decrease in age to the north, straddle the north-central Coast Ranges and document considerable right-lateral, strike-slip displacement along faults of the San Andreas system.

Structure within the Coast Ranges is among the most complex of any province in North America. Two extensive formations, the Franciscan assemblage and Great Valley sequence, comprise the bulk of the north-central Coast Ranges (Bailey et al. 1964). Eugeosynclinal rocks of Franciscan assemblage were subducted beneath coeval miogeosynclinal rocks of the Great Valley sequence in early Tertiary time along an eastward plunging subduction zone (McLaughi in and Stanley 1976). All classic indicators of subduction zones are displayed in this area (Hsu 1968): regional thrust sheets and imbricate thrust slabs, ophiolite sequences, melange belts, and blueschist-grade metamorphism. Complicated early Tertiary structure caused by subduction is overprinted by late Tertiary to Holocene right-lateral, strike-slip faulting along the San Andreas transform zone.

The crust within the western Coast Ranges is relatively thin because it consists primarily of complexly deformed sediments overlying oceanic crust; because of subduction and juxtaposition of the North American plate along the San Andreas fault zone, crustal thickness increases eastward (Fig. 3). Heat flow averages almost $84 \mathrm{~mW} / \mathrm{m}^{2}$ (>2 HFU), especially near the San Andreas transform zone (Lachenbruch and Sass 1980); yet thermal gradients only average 25 to $30^{\circ} \mathrm{C} / \mathrm{km}$ throughout the Coast Ranges (Kron and Heiken 1980; Guffanti and Nathenson 1980). Extreme seismic and tectonic activity is associated with faults of the San Andreas system, perhaps the most active system in the world. 
Thermal anomalies $84 \mathrm{~mW} / \mathrm{m}^{2}$ ( $\left.>2 \mathrm{HFU}\right)$ within this province are not significant (Lachenbruch and Sass 1980) except in The Geysers-Clear Lake region and in the Salton Trough. Although hot spring activity is concentrated at The GeysersClear Lake region, it is widespread throughout the Coast Ranges (Waring 1915 and Table I).

Large volumes of relatively intact crystalline basement, the preferred target for current HDR development, occur only in the Southern California batholith northeast of San Diego and in downfaulted rocks within the Salton Trough. Smaller masses of crystalline basement, which crop out as lenticular fault-bounded masses west of the San Andreas fault zone, are probably too fractured, too shallowly rooted, or too small to be considered as possible HDR reservoirs at this time. Deep Tertiary sedimentary basins such as the Ventura Basin have relatively low-to-average thermal gradients for this region and no known low-permeability reservoir unit at depth.

Low-permeability zones of high temperature are known to exist within metasedimentary and metavolcanic rocks of the Franciscan assemblage at relatively shallow depths in the Clear Lake region, but it is not known whether equivalent low-permeability beds are present in the rest of the Coast Ranges. Relatively low thermal gradients of $30^{\circ} \mathrm{C} / \mathrm{km}$ or less (Table I) will require HDR wells drilled to depths of at least $6 \mathrm{~km}$ for generation of electricity if indeed such low-permeability reservoir rocks do exist. If low-permeability horizons are eventually found to be widespread and HDR technology can handle the depth and complicated structure of the reservoir rocks, then, because they are close to large population centers, the Coast Ranges would have great potential for HDR energy development.

2. Central Valley. The Central Valley is a north-trending synclinal basin filled with marine and non-marine sedimentary rocks of Mesozoic to Quaternary age. This province is characterized by extremely low heat flow and thermal gradients. Depth to crystalline basement is $\gg>6 \mathrm{~km}$. Late Tertiary volcanism created the circular Sutter Buttes, a small sequence of intermediate to silicic domes, flows, and lahars north of Sacramento. Because of its age ( $2 \mathrm{Myr}$ ), this feature does not overlie a currently active magmatic source. (B. F. Curtis, personal communication, University of California, Berkeley, 1981). Warm brines (mostly $<100^{\circ} \mathrm{C}$ ), which co-exist with petroleum deposits in deeply buried sediments of the Central Valley, constitute the major geothermal 
potential of this province (White et al. 1973). Present HDR potential is nonexistent.

3. Sierra Nevada. The Sierra Nevada constitutes one of the largest continuous exposures of granitic crystalline rock in North America, but relatively low thermal gradients and heat flow will require drilling to depths $>6 \mathrm{~km}$ to achieve $200^{\circ} \mathrm{C}$. Mesozoic plutons and associated Paleozoic and Mesozoic metamorphic rocks of the Sierra Nevada form a northwest-trending belt more than $60 \mathrm{~km}$ wide and $400 \mathrm{~km}$ long. The western margin of this province is considered too structurally complex for HDR development because of Paleozoic to Mesozoic folding and thrusting, Mesozoic intrusions and veining, and Tertiary to Quaternary faulting. The province is characterized by low seismicity except at the western and eastern margins. Quaternary volcanism and hightemperature hydrothermal convection systems are uncommon except on the eastern margin. However, if HDR technology evolves beyond drilling limitations of $6 \mathrm{~km}$, then the Sierra Nevada has incredibly vast HDR reservoirs relatively close to population centers in California.

Additional possibilities for HDR development occur at Quaternary magmahydrothermal systems along the eastern margin of the province, such as the Long Valley caldera, Coso volcanic field, and possibly the Mono volcanic domes. (Long Valley is discussed in detail as a high-grade HDR target later.) These magmatic systems intrude and overlie downfaulted intrusive and metamorphic rocks similar to those exposed in the Sierra Nevada. As a result, the granitic rocks in these areas have high temperatures at relatively shallow depths due to hydrothermal and magmatic convection. All three magmatic systems occur at the boundary of the province with the northern Basin and Range tectonic province.

4. Basin and Range. This province, comprising most of Nevada, Utah, and southeastern California, is a vast region of north-trending horsts and grabens caused by pronounced extensional tectonic movement. It is characterized by thin crust ( $<35 \mathrm{~km}$ everywhere) and high thermal gradients and heat flow $84 \mathrm{~mW} / \mathrm{m}^{2}$ (>2 HFU) giving it excellent potential for HDR development.

Geology of the region is characterized primarily by Paleozoic to Mesozoic miogeosynclinal sedimentary rocks overlying various Precambrian units. Eastcentral Nevada contains extensive mid-Tertiary silicic volcanic centers that erupted voluminous ash-flow tuffs. Significant Quaternary silicic volcanism occurred only along the west margin of the province adjacent to the Sierra 
Nevada escarpment and in southwestern Utah at Roosevelt Hot Springs. Deep, late Tertiary grabens, for which the Basin and Range is renowned, are partly filled with thick unconsolidated clastic sequences.

The province is seismically active; two zones of unusually high seismicity occur in southwestern Nevada near the Las Vegas shear zone and in southern and eastern Utah in the Intermountain Seismic Belt.

Abundant hot springs discharge from range-bounding faults or fault intersections. Hot spring activity is concentrated in northern Nevada within the Battle Mountain heat flow high (Figs. 2 and 3), a broad thermal anomaly $105 \mathrm{~mW} / \mathrm{m}^{2}$ (>2.5 HFU) extending into Idaho that may be a transient effect of fairly recent crustal intrusion (Sass et al. 1980). Water in these small hydrothermal systems is heated by deep circulation along range-bounding faults. Major hydrothermal prospects exist at Dixie Valley, Beowawe Hot Springs, and the Desert Peak area.

Although we have not yet identified HDR prospects in the northern Basin and Range, the geologic setting at Roosevelt Hot Springs (discussed 1ater) is a model that is probably repeated in this province. At Roosevelt, the HDR target is downfaulted Tertiary granite and Precambrian gneiss underlying late Tertiary sediments of Milford Valley. The unconsolidated sedimentary cover may serve as an insulating thermal blanket. The shallow $260^{\circ} \mathrm{C}$ hydrothermal convection system east of the HDR target area is responsible for some of the shallow heat in the buried crystalline rocks but the regional thermal gradient and heat flow are quite high. Crystalline rocks are common in the Basin and Range (Fig. 3), and those near hydrothermal convection systems should be considered as candidates for HDR development.

Reservoir targets other than downfaulted crystalline rocks might be hydrothermally sealed Tertiary alluvium such as those found in some geothermal wells in Dixie Valley, Nevada. However, the technology for creating HDR reservoirs in low-permeability alluvium has not been developed and the volume of low-permeability alluvium may be small.

5. Colorado Plateau. The Colorado Plateau of Utah consists primarily of flat-lying Mesozoic and Paleozoic marine and continental margin strata overlying Precambrian basement. Tertiary intrusions such as the Henry, La Sal, and Abajo Mountains (Fig. 3) and Tertiary plugs and diatremes in southeastern Utah penetrate the older units but are not associated with any present thermal anomalies at depth. Basin and Range tectonics impinge on the west 
margin of the Colorado Plateau, but in general the province is characterized by broad monoclines and folds. No Quaternary volcanic fields or active hydrothermal systems are known in the province (Figs. 3 and 4).

Thick continental crust (Fig. 3) and low regional seismicity indicate that the region is underlain by intact, tectonically inactive crust. Heat flow and thermal gradients are relatively low (Fig. 3 and Table I). Although Precambrian basement rocks commonly reside at depths of only $3 \mathrm{~km}$, bottom-hole temperatures $\simeq 200^{\circ} \mathrm{C}$ will be approached only at depths of $6 \mathrm{~km}$ or more. These characteristics make HDR development prospects economically marginal, especially in view of the low regional population. These prospects can improve only if drilling and reservoir technology improve.

B. High-grade HDR Targets

At present, four systems offer the best potential in California, Nevada, and Utah for development of HDR geothermal resources al though their potentials vary because of uncertainties in depth, temperature, and physical properties of possible reservoir rocks. These are Long Valley Caldera, California; The Clear Lake Region, California; Salton Trough, California; and Roosevelt Hot Springs, Utah. Table II summarizes the fundamental HDR criteria at each of the four sites.

These four high-grade geothermal systems typify most major geothermal anomalies of the western U.S. All four systems have several geological features in common: (1) average heat flow $>84 \mathrm{~mW} / \mathrm{m}^{2}$ ( $\geq 2 \mathrm{HFU}$ ), (2) association with silicic volcanism <1 Myr, (3) surface hot springs and other near-surface hydrothermal phenomena, and (4) location in extensional structural settings. All four systems are also being actively explored for hydrothermal geothermal resources. In contrast, these igneous systems vary greatly with respect to volcanic styles, hydrothermal systems, and size of thermal anomalies (Muffler 1979; Goff and Waters 1980).

1. Long Valley Caldera, California. Long Valley (Fig. 2) is a $17 \mathrm{x}$ $32 \mathrm{~km}$ Quaternary age caldera formed by eruption of the Bishop Tuff about 0.7 Myr ago (Bailey et a1. 1976). It is presumably the surface manifestation of shallow silicic magma of almost batholithic size (Smith and Bailey 1968; Figs. 5 and 6), rivaled in the U.S. only by the young caldera systems of Yellowstone National Park, Wyoming, and the Jemez Mountains, New Mexico. Caldera formation was followed by rhyolitic eruptions and resurgent (structural) 


\section{TABLE II}

COMPARISON OF CRITICAL HDR DATA FROM FOUR HIGH-GRADE GEOTHERMAL SYSTEMS OF CALIFORNIA-NEVADA-UTAH

\begin{tabular}{|c|c|c|c|c|c|c|c|}
\hline & Reservoir Rock & Formation and Age & $\begin{array}{l}\text { Conductive } \\
\text { Temp. Grad. } \\
{ }^{\circ} \mathrm{C}\end{array}$ & $\begin{array}{l}\text { Depth of } \\
\text { Reservoir } \\
\text { km }\end{array}$ & $\begin{array}{l}\text { Temp, at } \\
{ }_{0}^{\circ} \mathrm{km}\end{array}$ & $\begin{array}{l}\text { Temp, at } \\
5 \mathrm{~km} \text {, } \\
{ }^{\circ} \mathrm{C}\end{array}$ & $\begin{array}{l}\text { Total Heat Energy } \\
\text { Remaining in } \\
\text { System, } 10^{18 \mathrm{~J}}\end{array}$ \\
\hline Long Valley Caldera, $C A^{b}$ & $\begin{array}{l}\text { Plutonic and meta- } \\
\text { morphic rocks }\end{array}$ & $\begin{array}{l}\text { Sierra-Nevada } \\
\text { Batholith; Mesozoic }\end{array}$ & 38 & $>3$ & $\sim 150$ & $\$ 250$ & 5,780 \\
\hline Clear Lake Region, CA & $\begin{array}{l}\text { Metagreywacke, } \\
\text { argillite, } \\
\text { and greenstone }\end{array}$ & $\begin{array}{l}\text { Franciscan Assem- } \\
\text { blage; Jurassic- } \\
\text { Eocene }\end{array}$ & $\sim 80^{C}$ & $\geq 2$ & $\sim 200$ & $>300$ & 3,610 \\
\hline \multirow[t]{2}{*}{ Salton Trough, CA } & $\begin{array}{l}\text { a. Cemented } \\
\text { alluvium }\end{array}$ & $\begin{array}{l}\text { Fluvial and deltaic } \\
\text { sediments; Plio- } \\
\text { Pleistocene }\end{array}$ & $\ldots e$ & $\geq 1$ & $250-350$ & - & $480^{f}$ \\
\hline & $\begin{array}{l}\text { b. Plutonic } \\
\text { rocks }\end{array}$ & $\begin{array}{l}\text { Southern California } \\
\text { Batholith; Mesozoic }\end{array}$ & -- & $\geq 2.5$ & -- & $>300 ?$ & -- \\
\hline $\begin{array}{l}\text { Roosevelt Hot } \\
\text { Spgs., UT }\end{array}$ & $\begin{array}{l}\text { Plutonic and } \\
\text { metamorphic rocks }\end{array}$ & $\begin{array}{l}\text { Mineral Mountains } \\
\text { pluton; Tertiary }\end{array}$ & $55-60$ & $>2$ & $150-200$ & $>300$ & $710^{9}$ \\
\hline
\end{tabular}

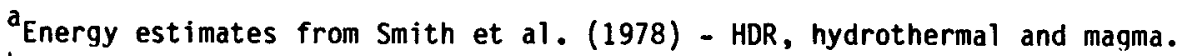

${ }^{b}$ Data assumes reservoir is developed beneath or west of resurgent dome in caldera; west caldera margin may be more attractive (Gambill 1981 ).

Estimate only from bottom-hole temperatures.

dVolume of impermeable alluvium in Salton Trough has not been estimated.

econductive gradients not known from hydrothermal system.

fEnergy estimate for hydrothermal systems within the U.S.; estimate too small for entire Salton Trough.

${ }^{g}$ Energy estimate for Roosevelt magmatic system; does not include greater Milford Valley area. 


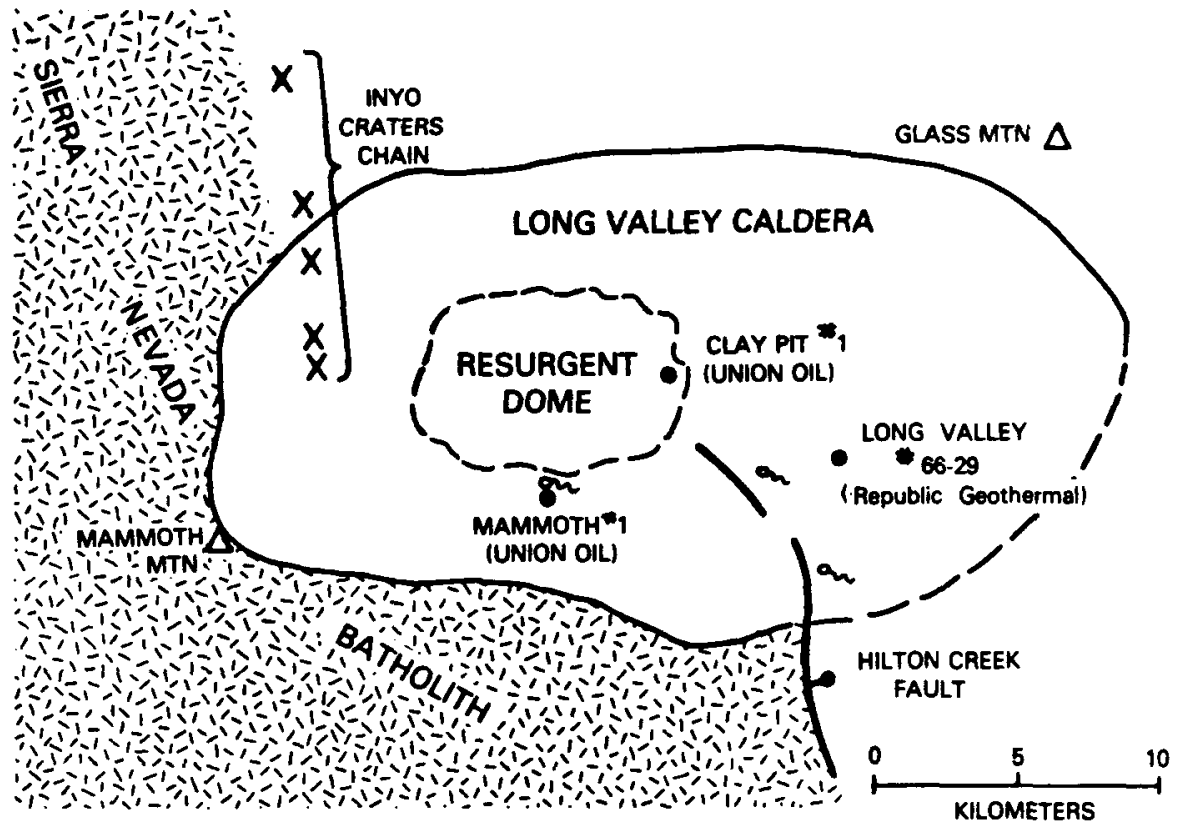

Fig. 5. Long Valley Caldera, California. Note the size of the Caldera and hydrothermal location of three deep wells.

doming in the caldera center, moat rhyolite eruptions, and rhyodacitic eruptions from outer ring fractures during the subsequent 0.68 to 0.05 Myr. Holocene rhyolitic and phreatic eruptions in the Inyo craters area on the northwestern side of the caldera are as young as 450 Myr. Long Valley is located at the boundary of the Sierra Nevada escarpment and the Basin and Range tectonic and physiographic provinces and comprises the most extensive Quaternary volcanic complex along this volcanically active boundary.

Volcanic rocks and associated sedimentary rocks overlie a faulted basement of Mesozoic plutonic rocks and Paleozoic metasedimentary rocks (Fig. 6). Seismic and gravity data interpreted by $\mathrm{Hill}$ (1976) and Kane et al. (1976), respectively, indicate a total thickness of Quaternary volcanic sedimentary fill of 2 to $3 \mathrm{~km}$. These interpretations have been partially confirmed by at least three drill holes of 2-km depth by Smith and Rex (1977) and W. Isherwood, personal communication, USGS. Hill (1976) also identified a low-velocity region beneath the caldera at a depth of 7 to $8 \mathrm{~km}$. Steeples and Iyer (1976) used teleseismic P-wave delay data to recognize a zone of attenuation from 7 to $25 \mathrm{~km}$. Both investigators show the low-velocity region confined beneath the western part of the caldera and conclude that the anomaly is caused by presence of magma or abnormally hot rock at shallow depths. Subjacent magma chamber 


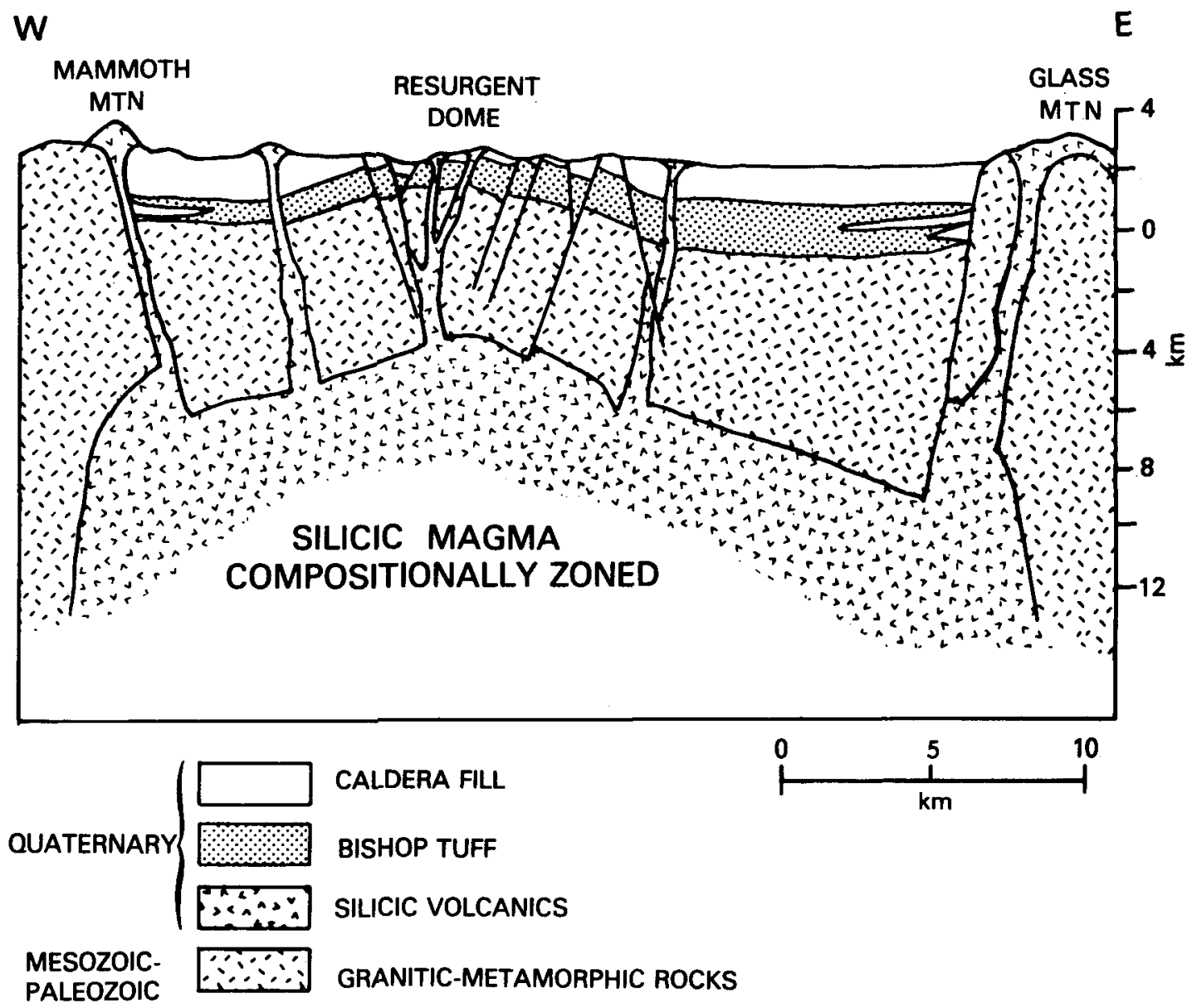

Fig. 6. Cross section of Long Valley caldera (adapted from Bailey et al. 1976). Subjacent magma chamber shown is controversial with regards to dimensions, depth, and percent of crystallization; however, the youngest eruptions are centered over the west side where geophysics indicates the best likelihood of present shallow magma.

shown is controversial with regards to dimensions, depth, and percent of crystallization; however, the youngest eruptions are centered over the west side where geophysics indicate the best likelihood of present shallow magma.

Sma11, hot water-dominated, hydrothermal systems discharge from faults and fractures associated with the resurgent dome (Mariner and Willey 1976; Lachenbruch et a1. 1976). Many of these faults are on strike with the Hilton Creek fault zone, a Sierra Nevada range-front fault. Maximum recorded discharge temperatures of the waters are $>90^{\circ} \mathrm{C}$; increased activity was observed during the earthquakes of May 1980. Exploration drilling to date, however, has not intersected large deposits of hot water economically suitable for 
generation of electricity beneath the caldera. Many wells penetrate hot aquifers perched at high stratigraphic levels that overlie low-permeability units of cooler temperature, mostly in Bishop Tuff. Prospects are not encouraging for hydrothermal development for electrical generation at Long Valley.

Two deep wells drilled by Union $0 i 1$ Co. (W. I sherwood, USGS, personal communication, 1980) have bottom-hole temperatures of 100 to $140^{\circ} \mathrm{C}$ at depths approaching $2 \mathrm{~km}$. The temperature gradient of the "best" hole (Clay Pit 1) is $38^{\circ} \mathrm{C} / \mathrm{km}$ in Quaternary (?) granite porphyry (M. Sorey, USGS, personal communication 1980).

Gambi11 (1981) recommended two target areas for development of HDR resources: first, the region between the western caldera margin and the resurgent dome and, second, the western lip of the caldera (Fig. 6). Both areas are close to the youngest silicic eruptions and, presumably, to high-level silicic melt or its recently crystallized equivalent. In the first target area, plutonic rocks at depth within the caldera may be highly faulted by the combined effects of collapse and resurgence, producing fault blocks too small or structuraliy complex to be of value to HDR. The second target area, on the western lip, has virtually the same structural setting as the prototype HDR system at Fenton Hill, New Mexico. In addition, Mesozoic plutonic rocks on the western lip have unusually high heat flow of $157 \mathrm{~mW} / \mathrm{m}^{-2}(3.75 \mathrm{HFU})$ (Lachenbruch et al. 1976). However, the relatively low thermal gradient of $38^{\circ} \mathrm{C} / \mathrm{km}$ makes Long Valley a less enticing choice for HDR development than the other three high-grade systems reviewed here.

2. The Geysers-Clear Lake Region, California. The Clear Lake region of northern California (Fig. 7) contains two geothermal regimes: a vapordominated (dry steam) system at The Geysers geothermal area and a larger, hot water province to the east and north (Goff et al. 1977). The Geysers now produces N800 MW(e) with as much as $2000 \mathrm{MW}(\mathrm{e})$ planned for the future. Reservoir rocks of both geothermal provinces (Fig. 8) are Jurassic to Eocene marine metasedimentary and metavolcanic rocks, and ophiolites of the Franciscan assemblage and (to a lesser extent) Great Valley sequence (McLaughlin and Stanley 1976). Bedrock structures are extremely complicated because of the combined effects of early Tertiary subduction and late Tertiary to Holocene strike-slip faulting. The heat source driving the hydrothermal systems is the relatively shallow silicic magma body(s) that erupted the rocks of the Clear Lake volcanic field of Plio-Pleistocene age (Hearn et al. 1981; in press). At least $35 \mathrm{~km}^{3}$ 
TABLE III

DATA FROM SELECTED DEEP GEOTHERMAL WELLS IN THE CLEAR LAKE REGION, CALIFORNIA (see Fig. 7 for 1ocations)

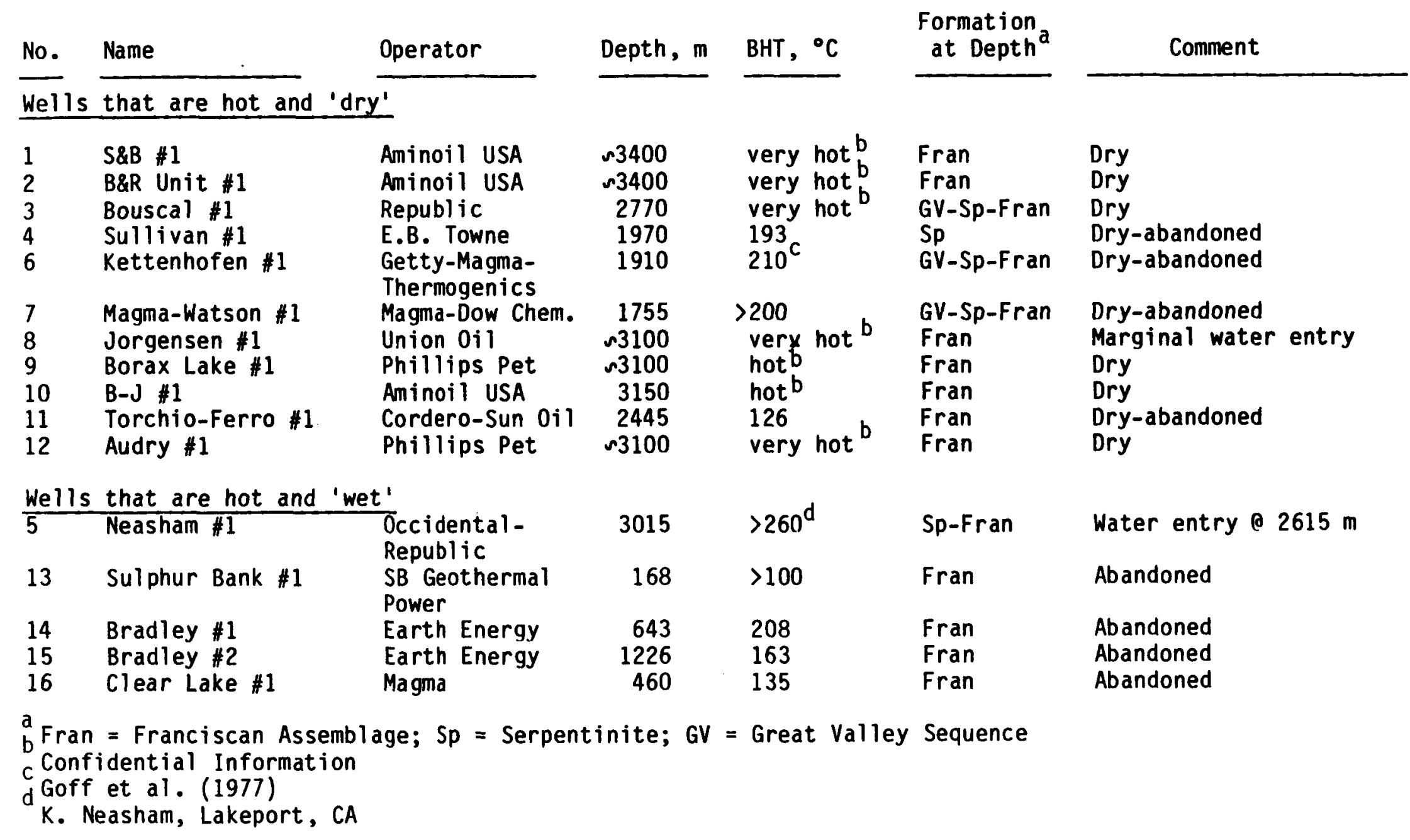



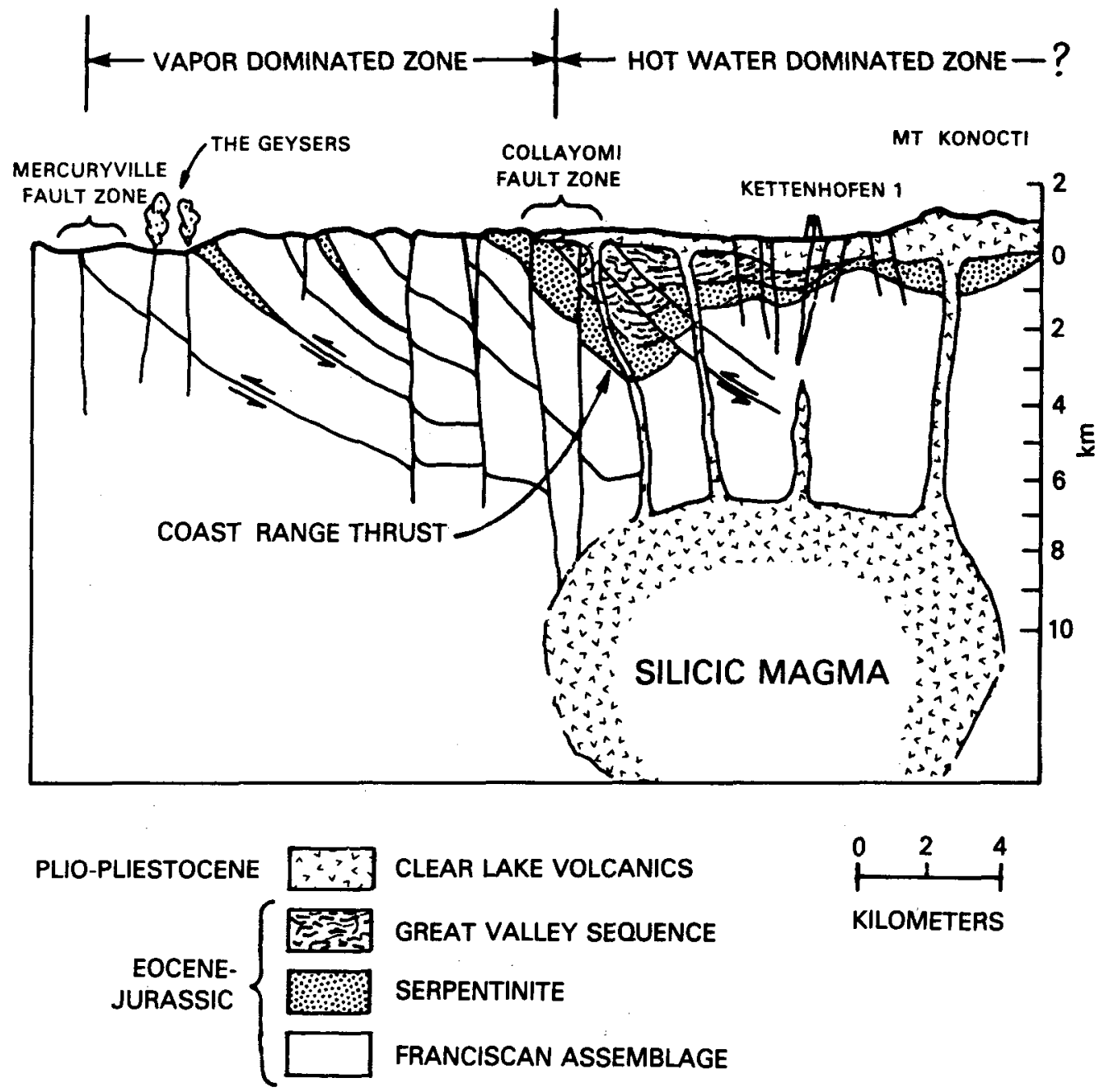

Fig. 8. Cross section of the Geysers-Clear Lake region (modified from Hearn et a1. 1976a and McLaugh1in 1976). showing relationship of Clear Lake volcanics to underlying Mesozoic basement rocks and the two geothermal provinces. Region of greatest interest for HDR development currently is northeast of Collayomi fault zone where small fault-controlled hot water reservoirs are found.

of dacite has been vented since $0.4 \mathrm{Myr}$ ago (Donnelly 1977). However, the youngest silicic and basaltic eruptions have occurred on the northern side of the volcanic field whereas The Geysers steam field is located southwest of it.

The top of the postulated magma body has been defined at depths of 7 to $10 \mathrm{~km}$ beneath Mt. Hannah on the basis of a 30-mgal gravity low, relatively shallow depths to Curie Pt. $\left(550^{\circ} \mathrm{C}\right)$ isotherm, and teleseismic P-wave attenuation >1 s (Chapman 1975; Isherwood 1976; Iyer and Hitchcock 1975). These anomalies all coincide with the Clear Lake volcanic field. 
The Clear Lake region is part of a highly active tectonic region, cut by northwest-trending, strike-slip faults related to the San Andreas transform zone (Donnelly et a1. 1980). Two of these faults, the Collayomi and Konocti Bay faults, show evidence for Quaternary right-lateral motion on the basis of offset volcanic units (Hearn et al. 1976b) and calculated fault-plane solutions (Bufe and Lester 1975). At least one northeast-trending, left-lateral fault and two north-trending belts of basaltic vents straddling the volcanic field indicate regional right-lateral shear.

The region of high interest as a target for HDR development is northeast of the Collayomi fault zone where small, fault-controlled hot water reservoirs are found. This area is apparently underlain by enormous quantities of lowpermeability rock (Fig. 8).

Exploration drilling of 12 deep wells into this hot water province has been relatively unproductive because of the low-permeability, although the wells are very hot. Temperature gradient data from these wells are proprietary, but most achieve temperatures of 200 to $250^{\circ} \mathrm{C}$ at depths of 2 to $3 \mathrm{~km}$ (e.g., Table III). Producing zones have been encountered only in known hydrothermal systems such as Sulphur Bank Mine and Wilbur Springs (White and Roberson 1962; Thompson 1979) or near probable active faults such as Sulphur Mound Mine. Geochemistry of surface hot springs suggests that the hot water province contains many unique small fault controlled systems (Goff 1980). Apparently, hydrothermal alterations resulting from the thermal anomaly, combined with chaotic early Tertiary structure in the Franciscan assemblage, tend to seal the reservoir rocks faster than the active tectonic environment can fracture them.

of the four high-grade systems reviewed here, the Clear Lake region is one of the most attractive because of high temperatures at shallow depths over a broad area. However, HDR development may not be possible with current technology because of uncertainties in developing a reservoir in structurally complex zeolite-grade metasedimentary rocks in a very active tectonic environment. Public visability and a power network close at hand are two possible attributes, but previous environmental issues have retarded geothermal growth in the region. Although Los Alamos has chosen a specific target prospect at this time, we intend to perform additional investigations in the area.

3. Salton Trough, California. The Salton Trough is a rift valley created by a system of right-lateral strike-slip transform faults, cross faults, 
and pull-apart basins (Fig. 9). This system extends from the East Pacific Rise through the Gulf of California, Mexicali and Imperial Valley, to the San Andreas fault zone east of the Salton Sea (Elders 1979). Filling of the trough by fluvial and deltaic sediments of an ancestral Colorado river has nearly kept pace with subsidence caused by active rift tectonics. These PlioPleistocene sediments have accumulated to depths of $6 \mathrm{~km}$ and more, over a crystalline basement of Mesozoic granitic rocks (Tewhey 1977) and Quaternary intrusions of oceanic (rift) basalt. Surface volcanism is limited to eruption of four obsidian-rich rhyolite domes south of the Salton Sea 0.06 Myr ago (Muffler and White 1969) and eruption of Cerro Prieto rhyodacite volcano in Mexico $\leq 0.1$ Myr ago (deBoer 1980). Dikes of basalt have been found in drill holes at the Cerro Prieto, Mexico, and Salton Sea geothermal fields.

The major hydrothermal systems of the trough are located within pul1apart basins, which are really small spreading centers (Elders 1979). These basins are bounded by active right-lateral faults such as the Brawley, Imperial, and Calipatria faults. Presumably each basin represents a place where basaltic magma is being injected into crystalline basement and Tertiary sediments of the trough. Hydrothermal reservoirs are moderately to extremely saline and range in temperature from 250 to $>350^{\circ} \mathrm{C}$. Producing depths are <1 to $3 \mathrm{~km}$ (Wollenberg et al. 1980).

HDR geothermal development cannot progress in the Salton Trough using current technology until the depth and structural configuration of crystalline basement rocks are better understood. For example, Tewhey (1977) reports depth-to-basement of $6 \mathrm{~km}$ or more beneath the Salton Sea geothermal field, making this an extremely deep HDR target. On the other hand, workers at the USGS (G. Fuis, unpublished data) report depths-to-basement of 2.5 to $4 \mathrm{~km}$ southwest of the Salton Sea field. Also, granitic rocks have been penetrated by several wells $\leq 2 \mathrm{~km}$ deep on the west side of the Cerro Prieto geothermal field (Fig. 10). Thus there may be horsts of crystalline rock, which would make good HDR drilling targets, within or along the margins of the Salton Trough at suitable depths.

Another detriment to HDR development may be the active tectonic environment of the Salton Trough. Transform and cross faults, associated with the central trough and the developing basins, are active today. Normal faults along the margins of the trough must also be considered active or potentially active. Fracturing caused by these faults and their intersections may cause 


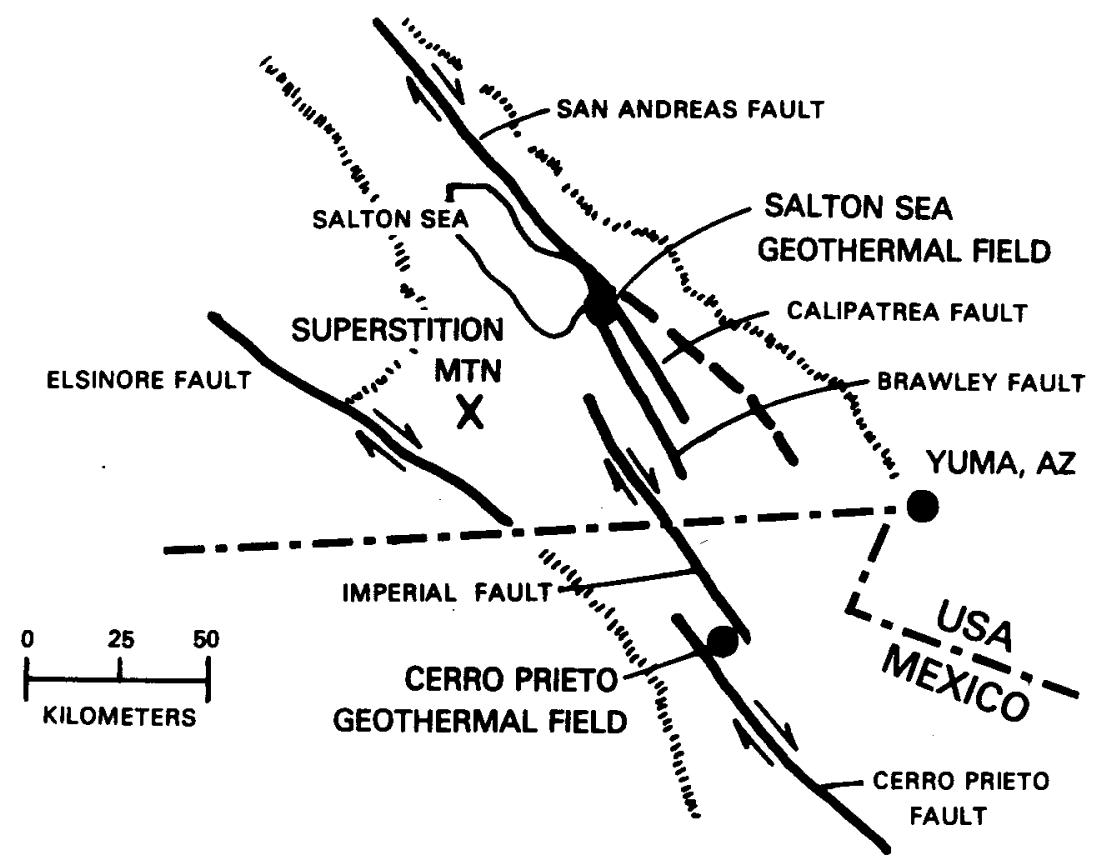

Fig. 9. Major faults of the Salton Trough showing major right-lateral strikeslip faults; hachured lines show margin of Trough.
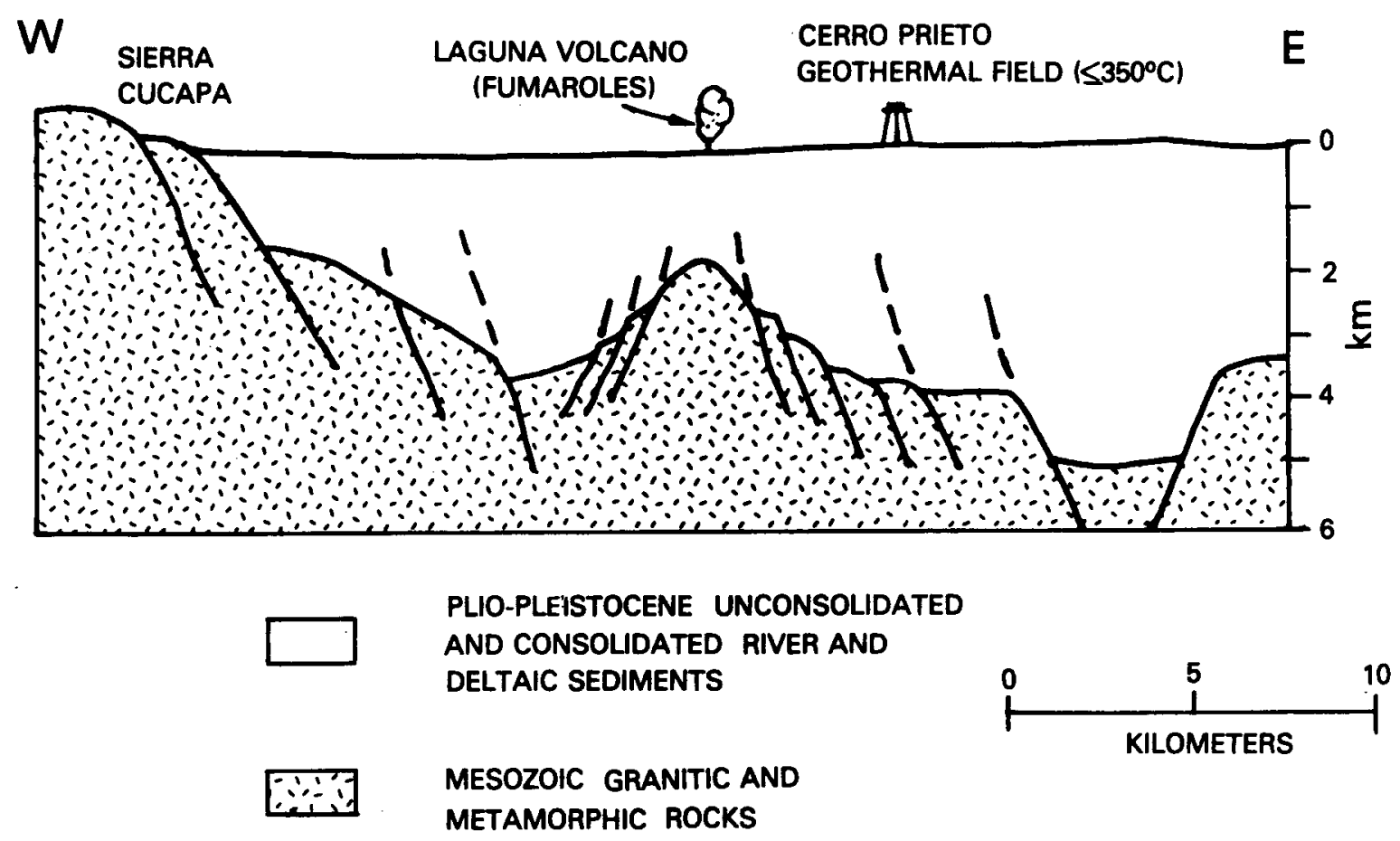

Fig. 10. Geologic cross section through the Cerro Prieto area showing faultblock structure on west margin of the Salton Trough (adapted from Penta Cruz and de la Pena 1979). 
creation and maintenance of a HDR reservoir to be technically infeasible unless large intact fault blocks greater than $1 \mathrm{~km}^{2}$ can be found at depth. Fault blocks of this size probably are present along the margins of the transform zone.

The Salton Trough contains another possible target for future HDR development if low-permeability alluvium associated with active hydrothermal systems can be used. Several explored geothermal reservoirs have extensive horizons of cemented alluvium surrounding or underlying the convecting hydrothermal fluids. Examples can be found at Westmoreland (M. Smith, Los Alamos National Laboratory, personal communication 1980) and at East Mesa (T. Meidav, independent geologist, personal communication 1980). This alternative is attractive if it can be determined that large volumes of low-permeability alluvium exist, because these high-temperature rocks are at relatively shallow depths. However, as previously pointed out, the technology for creating a HDR reservoir in rocks other than crystalline rocks has not been developed.

4. Roosevelt Hot Springs, Utah. Roosevelt Hot Springs geothermal area lies on the western flank of the Mineral Mountains (Fig. 11), a north-trending fault block $40 \mathrm{~km}$ long near the eastern margin of the Basin and Range tectonic province. Together with Milford Valley on the west, the Mineral Mountains are typical horst-graben structure. The range consists mostly of Mesozoic and Paleozoic strata and highly deformed Precambrian gneisses intruded by Tertiary granitic rocks of the Mineral Mountains pluton, the largest known intrusive body in Utah. Rhyolite domes, flows, and minor pyroclastic units, 0.8 to $0.5 \mathrm{Myr}$, surmount the crest of the range; three Quaternary basalt cones and associated flows lie on the northeastern flank (Ward et al. 1978; Nielson et al., 1978). Gravity, seismic, and teleseismic P-wave delay data yield inconclusive evidence of the presence of silicic magma at shallow crustal levels (Smith and Sbar 1974; Robinson and Iyer 1979).

Deep exploration drilling has discovered a $260^{\circ} \mathrm{C}$ hot water-dominated reservoir of moderate salinity (Parry et al., 1980) localized within a graben structure on the west flank of the range east of the Opal Mound fault. Fluids are found in both highand low-angle faults, but permeability is enhanced at intersections of the two fault types (Neilson et al., 1978).

Roosevelt typifies most Basin and Range hydrothermal systems in which fluids are heated by circulating deep along range-bounding faults in a tectonic 


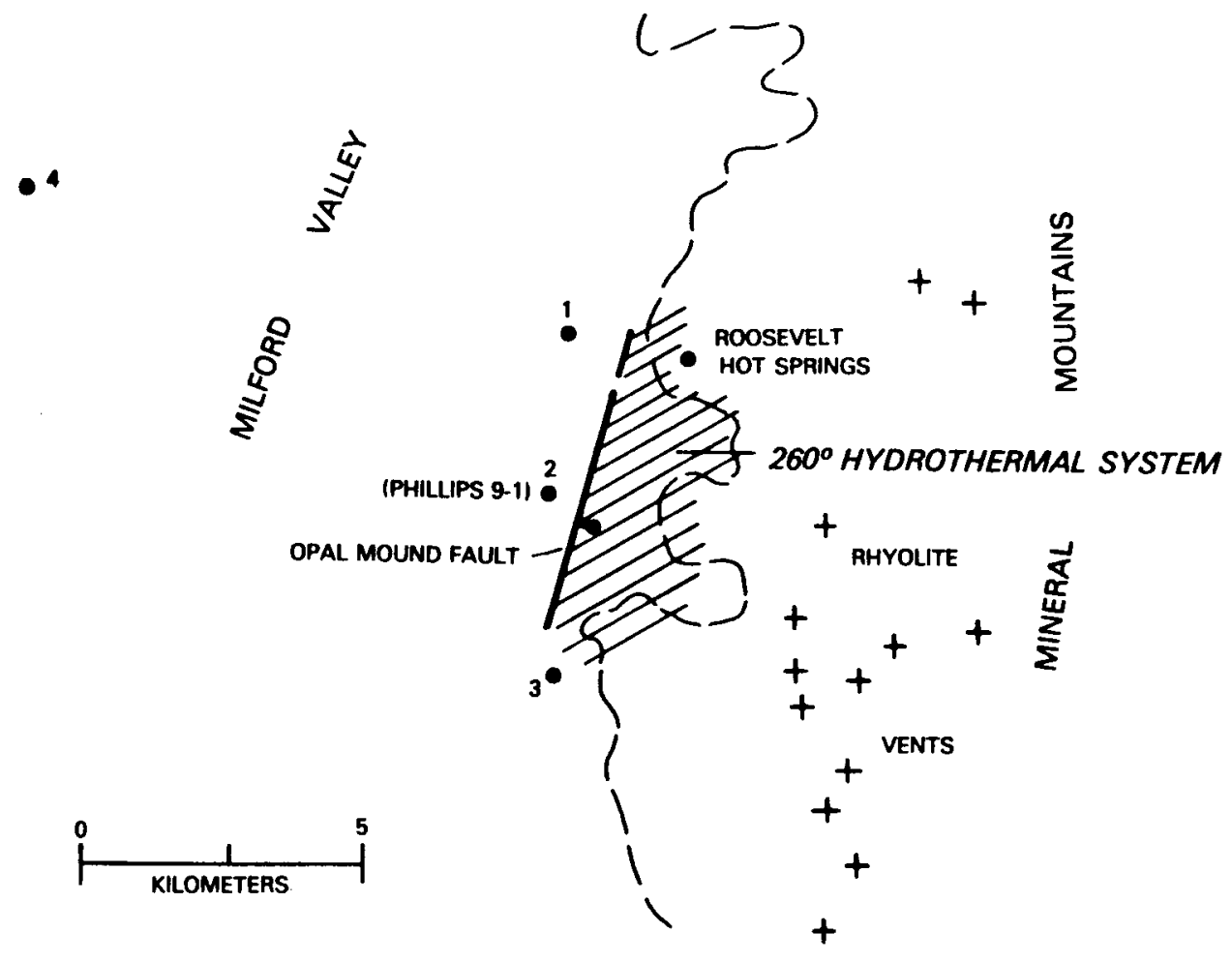

Fig. 11. Roosevelt Hot Spring area showing Opal Mound Fault which separates hydrothermal production zone (east) from zone of HDR interest. Numbers refer to hot dry wells listed in Table III.

regime of high heat flow. The additional association with shallow silicic magma or recently crystallized equivalents cannot be discounted but the nature of this association is somewhat speculative.

Four wells that are hot and relatively dry have been drilled west and south of the perimeter of the hydrothermal producing zone (Fig. 11, Table IV). At least three wells (e.g., Phillips 9-1) bottom in Tertiary granitic rocks resembling plutons of the Mineral Mountains (Fig. 12). Depths range from 2.1 to $3.8 \mathrm{~km}$ and temperature gradients are from 55 to $60^{\circ} \mathrm{C} / \mathrm{km}$. Bottom-hole temperatures are 200 to $230^{\circ} \mathrm{C}$. East (1981) conservatively estimates the Roosevelt thermal anomaly to have an area of $160 \mathrm{~km}^{2}$, of which 85 has good potential for HDR.

Roosevelt is an ideal candidate for future development of a HDR geothermal system. First, the depth and high temperature of the granitic reservoir rocks are suitable and the technology of establishing, a reservoir in granite is already known. Second, the fundamental geologic characteristics 

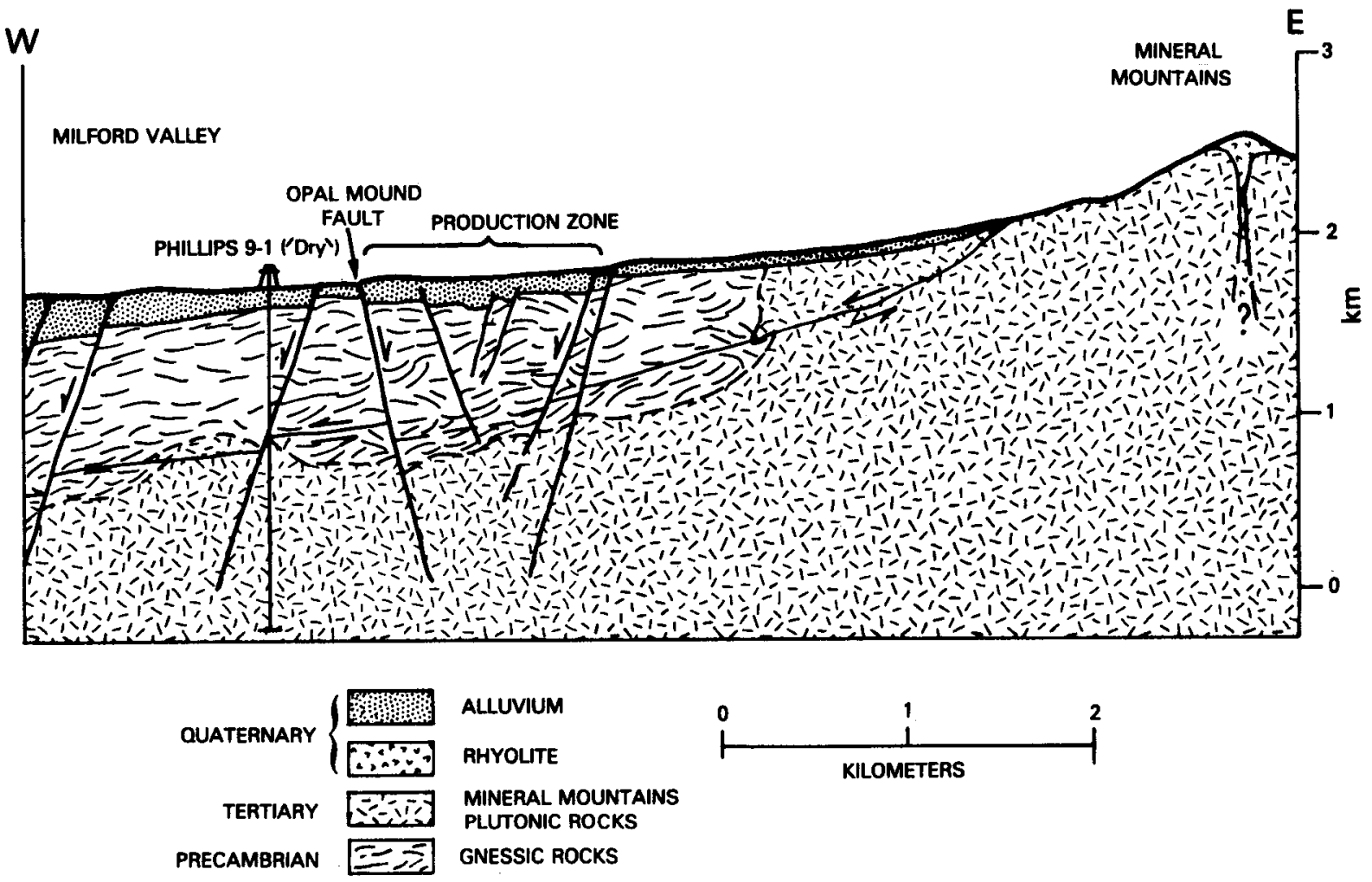

Fig. 12. Schematic cross section: Roosevelt Hot Springs area (modified from Nielson et al. 1978 and Glenn et al. 1981). The region of interest because of its HDR potential is located several kilometers west of the Opal Mound fault.

that make Roosevelt a good, hot dry rock prospect may occur throughout the Basin and Range province. Roosevelt will also have public visability and a power network close at hand now that Utah Power and Light Co. and Phillips Petroleum Co. have agreed to construct a $20 \mathrm{MW}(\mathrm{e})$ demonstration power plant using the existing hydrothermal system.

TABLE IV DATA FROM SELECTED DEEP GEOTHERMAL WELLS IN ROOSEVELT HOT SPRINGS REGION, UTAH (see Fig. 11 for locations).

\begin{tabular}{|c|c|c|c|c|c|c|}
\hline No. & Name & Operator & Depth, m & BHT, ${ }^{\circ} \mathrm{C}$ & $\begin{array}{c}\text { Formation at } \\
\text { at Depth }\end{array}$ & Comment \\
\hline 1 & Well 82-33 & Phillips Pet. & -- & -- & -- & $\begin{array}{l}\text { Dry; data } \\
\text { proprietary }\end{array}$ \\
\hline 2 & Well 9-1 a & Phillips Pet. & 2099 & 227 & Gneiss-Granite & Dry \\
\hline 3 & Utah State $52-21^{b}$ & Getty $0 i 1$ & 2281 & 202 & Gneiss-Granite & Dry \\
\hline 4 & Acord $1-26^{b}$ & $\begin{array}{l}\text { McCulloch-Geo. } \\
\text { Kinetics }\end{array}$ & 3855 & 230 & Granite & $\begin{array}{l}\text { Dry; heat flow = } \\
3.5 \mathrm{HFU}\end{array}$ \\
\hline
\end{tabular}

$\overline{\text { Glenn et al. (1981) }}$

beast (1981) 
III. PACIFIC NORTHWEST: REGIONAL AND SITE-SPECIFIC EVALUATIONS (Barbara H. Arney)

It is impossible to understand the regional heat flow or HDR potential of the northwestern U.S. without a basic discussion of the tectonic regime. Two important factors must be understood: (1) heat flow patterns in the northwest correspond to large, active tectonic and volcanic settings; and (2) most of the area is underlain by oceanic crust composed of interlayered marine sedimentary and volcanic rocks, not metamorphic and plutonic basement rocks. Therefore, the question of "depth to basement" is not applicable to most of this region. Possible "reservoir" rocks could be Mesozoic or Tertiary "granitic" intrusive, silicic domes, massive basalt flows, or altered volcaniclastic sediments. Little is known about the deep subsurface geology of most of the region, so it is difficult to assess at this time the probable size or extent of potential HDR reservoir rocks at depth. The regional geology is relatively complex, but high geothermal gradients, particularly along the margins of the Snake River Plain and in southeastern Oregon, make this region one of the most promising areas for HDR development.

Numerous hot springs are known, especially throughout Oregon and Idaho (Berry et al. 1980). Most of these are associated with fault zones. As a result, many of the anomalously high gradient measurements are caused by convecting hot water along fault zones and do not reflect the true thermal gradient at depth. Hot dry rock assessments should not be misled by local and sometimes extreme anomalies, for example, by lateral transmission of hot water along aquifers cut by faults. For a regional assessment of the HDR resource base only thermal anomalies that are uniform over tens to thousands of $\mathrm{km}^{2}$ are considered. Once the regional anomalies and potential reservoir rocks are understood, selection of HDR sites can proceed based on needs of available users.

Increased population and recent drought years indicate that hydroelectric power can no longer meet the regional needs of the northwest. Major cities such as Portland, Seattle, and Vancouver, B.C. and major agricultural and forest product processors could benefit from development of HDR in the northwest.

This report first examines the Pacific Northwest region as a whole, discussing its HDR potential in terms of its geology, heat flow, crustal thickness, and reservoir rock, and then summarizes prospects for developing HDR energy at certain sites deemed the most promising. 


\section{A. Geology of Region}

The Pacific Northwest is a region of active tectonism. During Mesozoic time, an older volcanic arc complex apparently collided with the North American continent resulting in subduction along the continental margin (Hyndman 1979). Rocks from the volcanic arc complex and the associated subduction zone are exposed in the Snake River Canyon along the border of southeastern Washington with Idaho and in western Idaho and northeastern Oregon. The Idaho batholith, composed of a complex group of plutons, was intruded during late Cretaceous and early Tertiary time, after subduction associated with the arc continent collision. West of the Idaho batholith, between it and the arc-subduction complex, the old continental margin is marked by complex Precambrian metasedimentary rocks. Farther south, between the batholith and the Mesozoic marine strata and volcanic fields of east central Oregon, the margin is concealed by Tertiary and Quaternary volcanic rocks and cannot be located. Cenozoic subduction west (seaward) of both the old continental margin and the Mesozoic volcanic arc resulted in folding and imbricate faulting of marine sediments and volcanic rocks to form the Coast Ranges. The still active volcanic chain of the high Cascades is a result of this subduction episode (B1ackwe11 1974).

Idaho consists mostly of Precambrian and Paleozoic continental crustal rocks intruded by Cretaceous and early Tertiary plutons of the Idaho batholith. The Snake River plain extends in an arc across the southern part of the state. The plain is fault bounded and filled with Cenozoic mafic and silicic volcanic rocks. It is not known if the batholith and older continental crust extend beneath the plain under the volcanic cover or if they have been rifted apart. Southeast of the Snake River plain, the basement is composed of typical Precambrian metamorphic and intrusive rocks of the Basin and Range province. On the southwest, the Owyhee Mountains are composed of Tertiary and Quaternary volcanic rocks with few outcrops of Cretaceous and Tertiary granitic intrusive bodies. It is likely, from Maxwell's (1974) reconstruction, that the plutonic rocks southwest of the plain intrude the arc-subduction complex rather than Precambrian continental crust.

In summary, a latitudinal cross section across the northwestern U.S. would show uplifted and stacked thrust-faulted marine sediments and slabs of obducted oceanic crust and upper mantle material in the coast Ranges and $\mathrm{K}$ lamath Mountains. The next major province to the east is the Cascades Range, 
an arc-type chain of volcanoes that have erupted through uplifted oceanic crust. A back-arc region lies to the east and consists of uplifted oceanic crust of volcanic and sedimentary rocks covered by continental flood basalts and silicic ash flow tuffs. This region forms the High Lava plains, Blue Mountain uplift, and Columbia Plateau. Finally, in northern Washington and adjacent central Idaho the section crosses the old continental margin and encounters early Paleozoic and Precambrian sedimentary and metasedimentary rocks that have been intruded by many Mesozoic age plutons, the largest of which is the Idaho batholith. East and southeast of the Idaho batholith the old continental crust is block-faulted in typical basin and range style.

The north-trending geologic provinces (Fig. 13) in Oregon and Washington are transected by major northwest-trending lineaments and fault zones such as

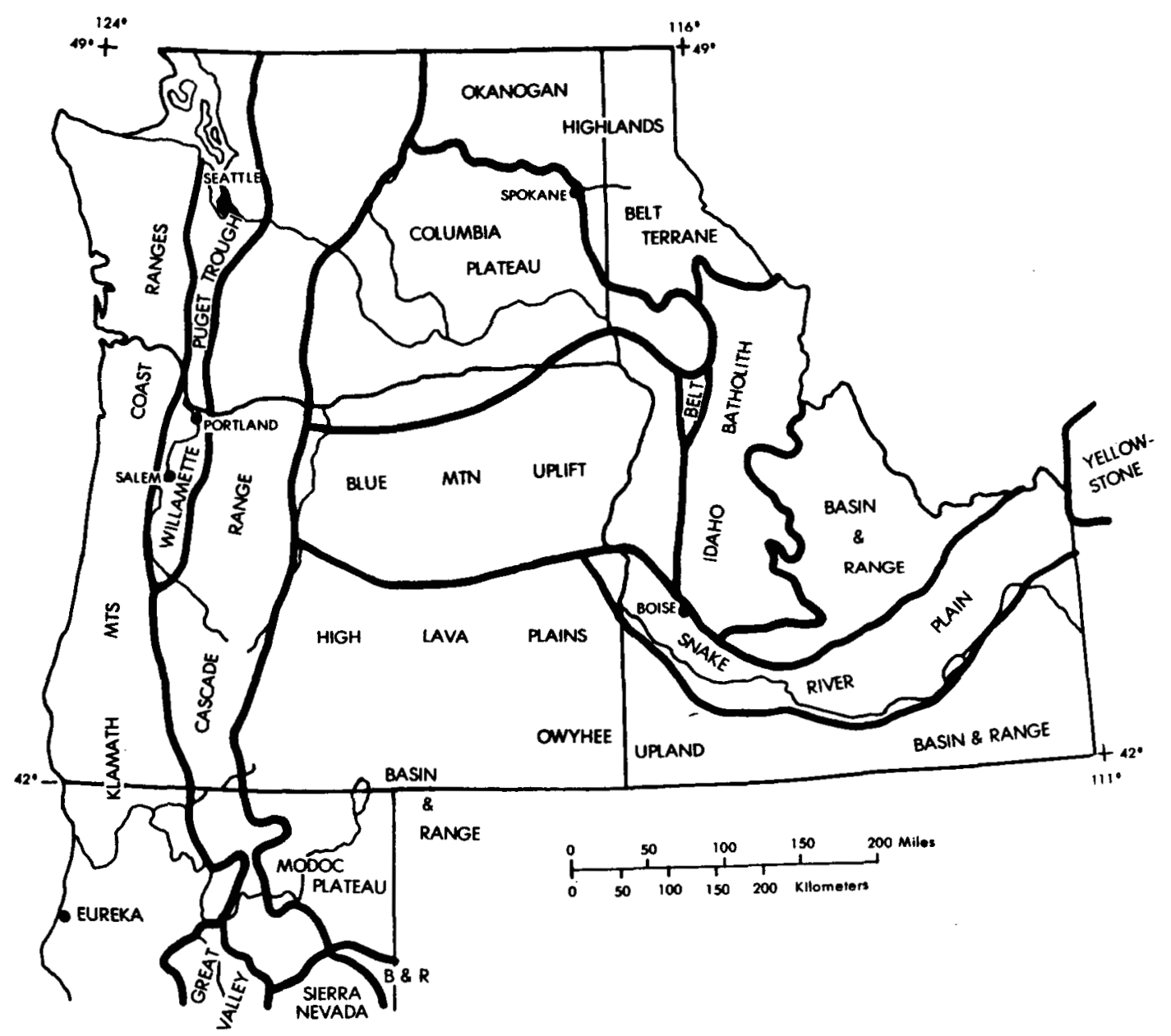

Fig. 13. Geologic provinces of the Northwestern United States. 
the Oregon-01ympic-Wallowa lineament, John Day fault zone, and Brothers fault zone. The Brothers fault zone in Oregon is a region of especially high heat flow (Blackwell et al. 1978), but the magnitude of the published geothermal gradients measurements may partly reflect deeply circulating ground water. The zone has also been one of crustal weakness along which a number of late Tertiary and Quaternary silicic domes have been intruded. The other northwesttrending fault zones are not reflected in the heat-flow patterns.

B. Volcanic Activity

The extensive Tertiary and Quaternary volcanic activity in this region has left Cenozoic age igneous rocks covering more than half the area (Fig. 14).
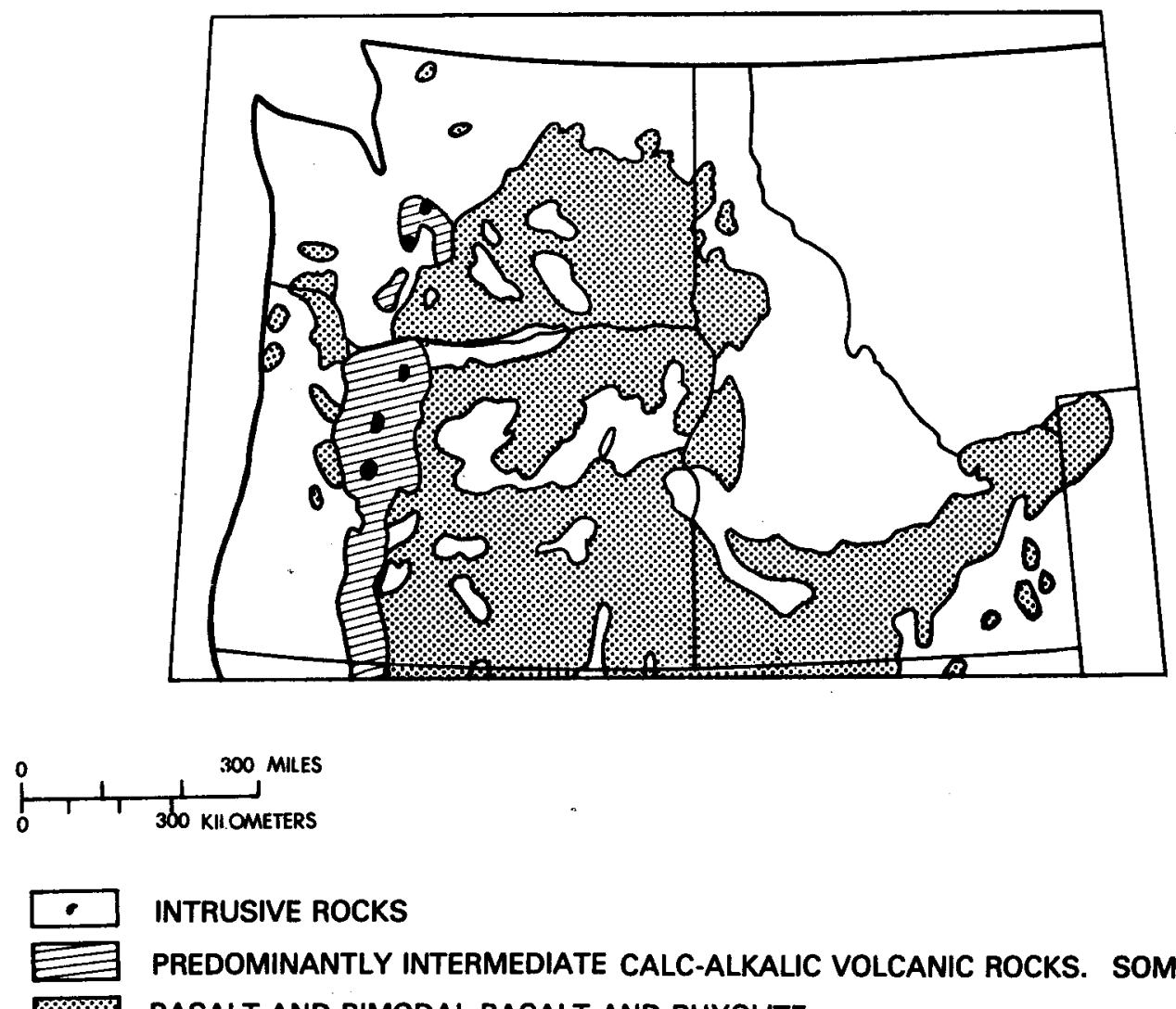

INTRUSIVE ROCKS

PREDOMINANTLY INTERMEDIATE CALC-ALKALIC VOLCANIC ROCKS. SOME BASALT

BASALT AND BIMODAL BASALT AND RHYOLITE

Fig. 14. Late Cenozoic (17 Myr to present) igneous rocks of western United States. Used with permission of GSA. 
Much of this is flood basalt of the Columbia Plateau, located in southeast Washington and northeast Oregon, and of the Snake River plain in Idaho. Southeastern Oregon is also largely covered by basalt. In southeastern Oregon and in Idaho, silicic ash flow tuffs predate or are contemporaneous with the basalt. Many silicic domes occur in southeastern Oregon. The youngest dated is 0.58 Myr (Macleod et al. 1976). The Cascade Range is a north-trending volcanic chain surmounted by large andesitic stratovolcanoes, some of which are active (Lassen 1914-17; Mt. Baker, 1975-76; Mt. St. Helens, 1980).

\section{Heat Flow}

Heat-flow patterns in the northwestern U.S. closely correspond to the geologic provinces--low heat flow over subduction zones west of the Cascades volcanic arc and high heat flow from the volcanic arc inward for several hundred kilometers (Blackwel1 1974). Most of the heat-flow measurements in the northwest have been done by David Blackwell of Southern Methodist University (SMU) in cooperation with state geological surveys. The Oregon Department of Geology and Mineral Industries (DOGAMI) has published much information for the state of Oregon. As open-file reports, the state of Idaho has published information on selected areas in their Water Resources Bulletin no. 30, and some information on the state of Washington is available in Information Circulars 50 and 62 and open-file report 80-9. The USGS has investigated gradients or heat flow in California but has not published final reports on these data, except for Mase et a1. 1980.

To better understand the heat-flow data that are available, it is important to keep some simple concepts in mind. Generally, heat flow is calculated from geothermal gradients measured in existing wells or in holes drilled specifically for that purpose. In older, stable parts of the continents, conductive heat flow is the result of two components: flux from the lower crust and/or upper mantle, and radiogenic heat, from the decay of uranium, thorium, and potassium in crustal rocks (especially granitic rocks and shales). In areas characterized by young igneous activity, part of the observed flux may be explained by conductive heat transfer related to buried intrusions.

The problem with estimating conductive heat flow is that temperature gradient measurements are often strongly affected by nearby convective systems. Particularly in tectonically active areas such as the western U.S., circulation of ground water through deep fault systems results in elevated gradients. 
Extensive convection in the vicinity of magma bodies also causes local anomalies. In some areas of the northwest, good heat-flow measurements are difficult to obtain because widespread basalt sheets act as aquifers for cold and hot water, and gradients measured in wells less than $500 \mathrm{~m}$ are likely to give more information on local hydrologic conditions than on regional temperatures. This situation occurs in the eastern Snake River plain, parts of the Columbia Plateau, Modoc Plauteau, and much of central and eastern Oregon.

Over much of the northwest the heat flow measured is largely from the mantle because there are few large granitic bodies to add a radiogenic crustal component. Exceptions to this are the Idaho batholith and much of the Okanogan Highland. Both the Cascade Range and Snake River plain have higher than average heat flow, which is probably related to recent volcanism and possible magmatic intrusions (Brott et a1. 1978; Blackwell and Steele 1979).

Table $V$ gives heat-flow measurements for the geologic provinces of Oregon and Washington and those available for Idaho and northern California.

The heat-flow map in Fig. 15 has been contoured to omit local anomalies that are probably related to hydrothermal systems. The relative low over the

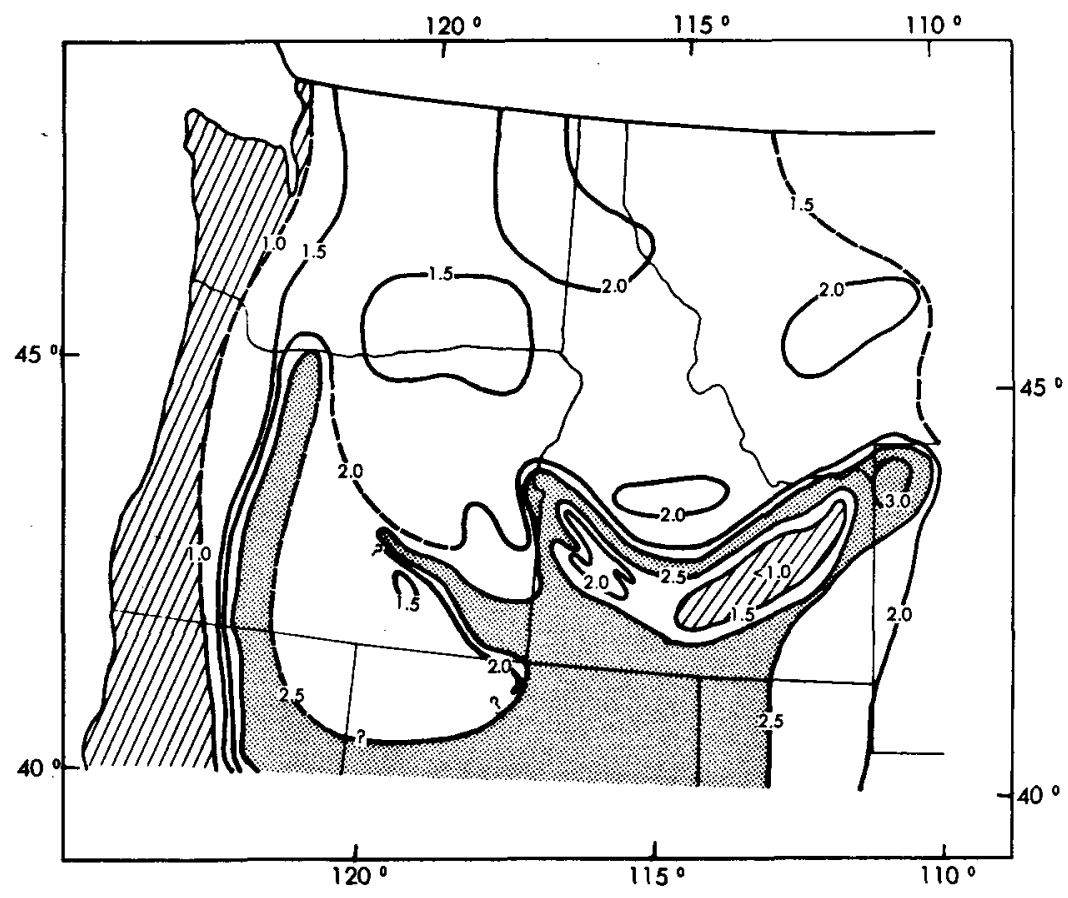

Fig. 15. Heat-flow map of the northwestern United States. Contours are in heat-flow units. Used with permission of GSA. 
HEAT FLOW IN THE NORTHWEST UN ITED STATES

Province

$\underline{\mathrm{mW} / \mathrm{m}^{2}}$

$\underline{\text { HFU }}$

Washingtona

Coast Ranges and Puget Trough

$33-38$

$0.8-0.9$

Cascades

$50-71$

$1.2-1.7$

Okanogan Highlands

$67-100$

$1.6-2.4$

Columbia Plateau

$59-71$

$1.4-1.7$

Oregon ${ }^{b}$

Coast Ranges - Willamette Valley$\mathrm{K}$ lamath Mountains

Cascade Range

Columbia Plateau

Blue Mountains Uplift

High Lava Plains, Basin and Range and Owyhee Uplands

$\begin{array}{ll}35-40 & 0.85-0.97 \\ 45-105 & 1.1-2.5 \\ 62 & 1.5 \\ 70 & 1.7 \\ 86-119 & 2.1-2.8\end{array}$

Idaho

Okanogan-Be1t Terrane

Idaho Batholithc

Snake River Plain (West) ${ }^{c}$ (East)d(a)
$67-92$

$84-105$

$1.6-2.2$

2.0

$2.0-2.5$

California
N. Coast Ranges - Klamath Mountainse Cascades d(b)
$31-63$
$0.75-1.5$
Modoc Plateau, and Basin and Range $f$
$70-100$
$1.7-2.4$

a Ranges from Fig. 1 in Blackwell (1974).

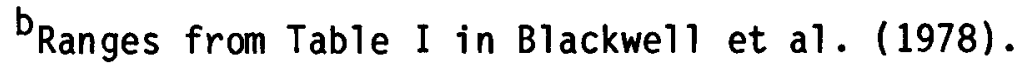

${ }^{C}$ Regional averages from text in Sass et al. (1980).

dDifficult to measure because of hydrologic effects: (a) Sass et al. (1980), (b) Mase et a1. (1980a).

e Range from Contour interval in Fig. 13.5 in Sass et al. (1980).

Range from Mase et al. (1980a). 
eastern Snake River plain is a result of the near surface hydrology previously discussed. The low over the Columbia Plateau may reflect the absence of granitic rocks, and hence, most of the radiogenic component of heat flow. Measurements in the Columbia Plateau may also have been affected by the flow of cold ground water in permeable basalts and interbedded sedimentary and volcaniclastic rocks (Sass et al. 1980).

D. Crustal Structure as Measured by Seismic Refraction Studies

Seismic surveys are available over most of the major structures in the northwest (Fig. 16). An extensive seismic survey of the western US was performed in 1960-1962 using explosions at the Nevada Test Site and elsewhere (Pakiser 1963). Additional studies using large explosions in British Columbia are described by Johnson and Couch (1970) and Hill (1972). In 1978 a cooperative seismic survey of the eastern Snake River plain was undertaken (Braile et al. 1979; Braile and Smith 1979; 01 sen et al. 1980).

Using the seismic profiles along survey lines shown in Fig. 16, Smith (1978) compiled a crustal thickness map of the western U.S. (Fig. 17). The recent studies in the eastern Snake River plain indicate that the $40 \mathrm{~km}$ thick contour can be continued along southern Idaho, because the crust in the eastern Snake River plain is also $40 \mathrm{~km}$ thick.

Generally the crust in the northwest U.S. is thin $(20 \mathrm{~km})$ along the coast but thickens eastward. The Basin and Range province has anomalously thin crust $(25-30 \mathrm{~km})$ extending into southeastern Oregon and parts of southern Idaho. The Columbia Plateau also has a thinner crust ( $25 \mathrm{~km}$ thick) than surrounding areas. Unlike the Columbia Plateau, the crust thickens under the Snake River plain to $40 \mathrm{~km}$. In the western Snake River plain the granitic crust appears to be discontinuous under the plain; beneath the eastern Snake River plain the granitic layer appears continuous and not rifted.

Crustal thickness is not a diagnostic parameter of geothermal potential in the northwestern U.S. High heat flow is found in the thick crust in the Snake River plain and in the thinner crust in southeast Oregon. The heat flow is very low in the thin crust above the subduction zone along the West coast. Heat-flow patterns mainly reflect late Cenozoic tectonic regimes in the region (Roy et al. 1968, 1972). 


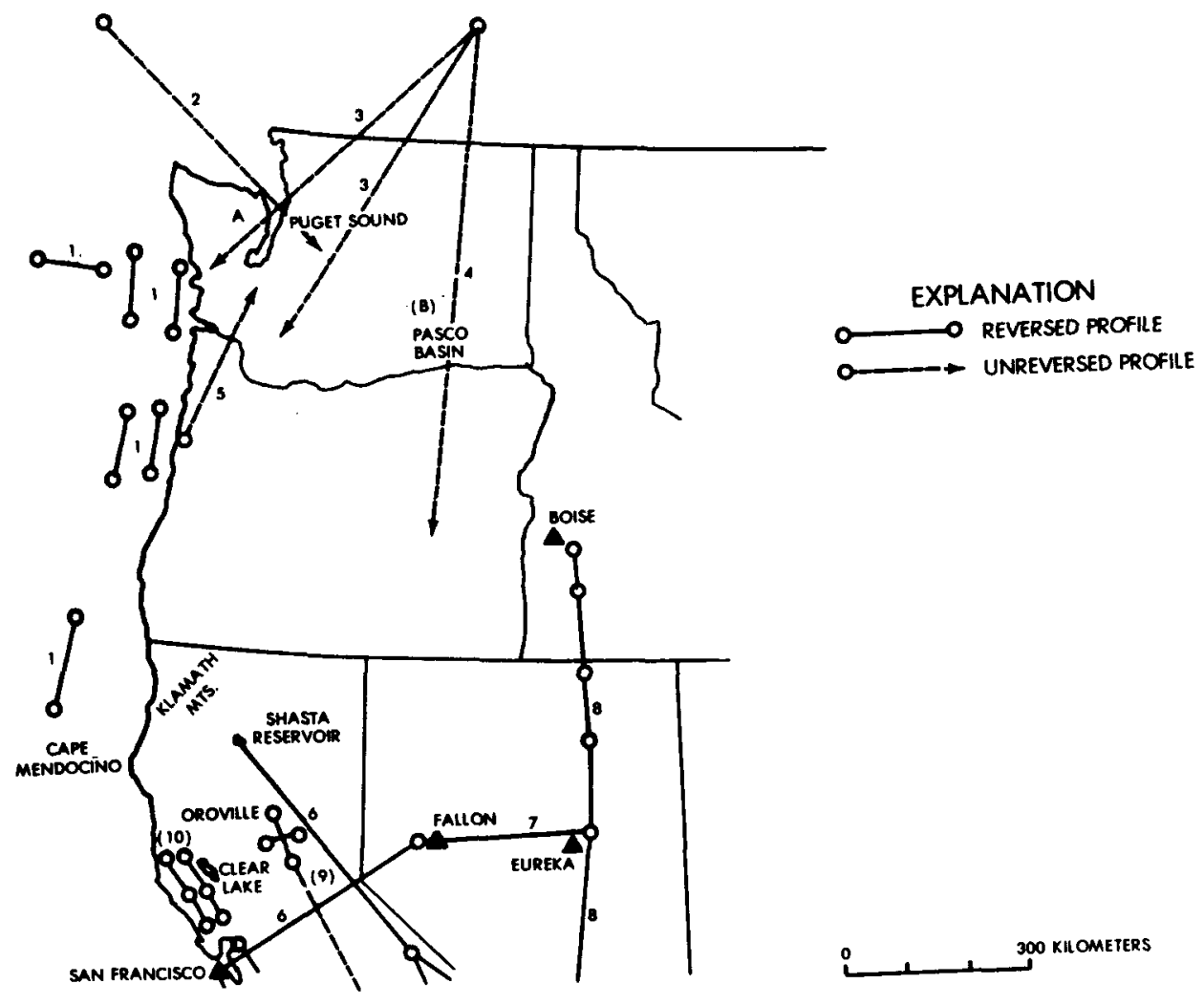

Fig. 16. Index map showing location of seismic refraction profiles and regional seismic network studies based on local earthquakes and quarry blast data. Unpublished results indicated by parenthesis. Used with permission of GSA.

Crustal radiogenic heat production must be considered when interpreting heat flow. Combined with information on tectonic regime and lateral changes in the measured heat flow, crustal radioactivity can be used to infer the depth of heat sources and temperature at depth (Roy et al. 1968, 1972). For example, if the regional conductive heat flux is $\geq 100 \mathrm{~mW} / \mathrm{m}^{2}(>2.4 \mathrm{HFU})$ and if the crustal heat production is low ( $<5 \mathrm{HGU}$ ), and if the borders of the positive heat-flow region are narrow, it is likely that the heat source exists at shallow depths. If in a similar region the heat flow were to change gradually over a broad area, the source of the heat would probably be deep. For most of the northwest, the amount of data available is not sufficient to permit such detailed interpretations. 
E. Gravity and Magnetic Surveys

Although gravity and aeromagnetic data are available for much of the northwest, regional interpretations are few; two that have been discussed are Oregon (Thiruvathurkal et al. 1970) and the Snake River plain in Idaho (Hill 1963; Mabey 1976, 1978a). The western Snake River plain is coincident with a general gravity high that includes three smaller en echelon highs elongated parallel to the axis of the plain. These are interpreted as basalt-filled fissures (Hill 1963). Gravity data suggest that granitic rock of the Idaho batholith is not continuous beneath the plain. A positive magnetic anomaly along the southern edge of the plain and a negative anomaly near the northern edge may be interpreted as a layer of normally polarized basalt filling the plain (Mabey 1976, 1978a). Mabey's (1976) interpretation was based on seismic data showing crustal thickening to $42 \mathrm{~km}$ under the western Snake River plain.

The eastern Snake River plain displays more complex gravity and magnetic patterns. A broad gravity high exists over this part of the plain. The gravity patterns associated with Basin and Range structures both northwest and southeast of the plain do not extend beneath it, but interpretations of both gravity and magnetic data suggest that pre-Cenozoic rocks extend beneath the eastern Snake River plain and that rifting, which is interpreted for the western Snake River plain, does not occur here (Mabey 1978a, 1978b). Mabey (1978b) and La Fehr and Pakiser (1962) believe that there is about $6 \mathrm{~km}$ of crustal thinning under the eastern Snake River plain. This figure does not agree with the most recent seismic interpretation, which is that total crustal thickening under the eastern Snake River plain is the same as under the western Snake River plain (Braile et al. 1979; 01sen et al. 1980).

Thiruvathukal et al. (1970) have studied the regional gravity field of Oregon. Their analysis of 4000 gravity measurements indicates that, taken as one large prism, Oregon is in approximate mass equilibrium with a standard earth column. Since there is not adequate seismic control, they assume constant crust and mantle densities over the entire state. They believe that crustal thicknesses vary from less than $20 \mathrm{~km}$ under the Coast Range to $45 \mathrm{~km}$ under southeastern Oregon. However, if southeastern Oregon is underlain by an upper mantle of low density similar to that under the Basin and Range province to the south, crustal thickness for that area would be less than the $45 \mathrm{~km}$ calculated. Gravity data show no evidence for crustal roots under the Coast 
Range or under the Cascades, which agrees with the seismic interpretations of Johnson and Couch (1970).

Weston Geophysical Research, Inc., has compiled aeromagnetic surveys covering most of Washington and southern Oregon for Washington Public Power Supply System (1978). These maps are useful in interpreting the geology and structure and may help locate Mesozoic plutons not exposed at the surface. Aeromagnetic maps available for the Snake River plain were used by Mabey in his interpretation of the gravity data. An aeromagnetic map for the entire state of Idaho has been published by the USGS (1978).

\section{F. Reservoir Rocks}

As suggested previously, the heat flow in the northwest, east of the western Cascade Range, is sufficiently high to indicate the presence of relatively shallow geothermal resources over large areas. Thus, HDR development is more likely to be limited by the absence of appropriate reservoir rocks than by suitable temperatures. Present HDR technology requires low permeability, unfractured (or sealed) crystalline reservoir rock. Granitic intrusive bodies in the northwest are mostly Mesozoic in age (a few are Tertiary) and occur in northeastern Washington, Idaho, and northeastern Oregon. Some epizonal plutons are exposed in the northern Cascades.

Precambrian rocks consist mostly of metasediments of, or similar to, the Belt group of Idaho. These might prove of low enough permeability to be used as reservoir rocks in some areas. Precambrian rocks crop out in northern and eastern Washington and in Idaho, both north and east of the Idaho batholith.

Most of the remainder of the northwest consists of basalt flows and marine sediments and it is not known how permeable these formations may be at depth. The basalts and interbedded sediments serve as aquifers throughout the area, and fluid flow within these formations has been observed as deep as 2.5 to $3 \mathrm{~km}$. Alternative HDR systems consisting of water pumped into permeable, but not naturally producing, formations have not yet been tried. To fully develop the geothermal potential of the northwest it will probably be necessary to develop this technique (Bodvarsson 1975).

Using present HDR technology, the most promising areas for development are the margins of the Snake River plain (using the Idaho batholith as reservoir rock), the Brothers fault zone and the western Snake River Basin (using silicic domes and small intrusions as reservoirs), and the Okanogan Highlands 
of Washington (using Mesozoic intrusive rocks, preferably those insulated by thick sedimentary sequences).

G. Summaries of Prospective HDR Sites Examined by LOS Alamos

Mountain Home Prospect, Western Snake River Plain

One of the most promising areas for hot dry rock development in the northwest is along the margins of the western Snake River plain. The Snake River plain is an arcuate depression in southern Idaho filled with Tertiary and Quaternary age volcanic rocks, which are younger to the east. The margins of the western Snake River plain are fault bounded with at least $2743 \mathrm{~m}(9000 \mathrm{ft})$ vertical displacement along the northern margin (Malde 1959) and with somewhat less displacement on faults of the southern margin. The Idaho batholith lies just north of the Snake River plain, but it is not known how far it extends beneath the plain.

The average heat flow is greater along the margins of the plain $105 \mathrm{~mW} / \mathrm{m}^{2}$ (2.5 HFU) than within the plain $75 \mathrm{~mW} / \mathrm{m}^{2}$ (1.8 HFU) (Brott et al. 1978). Part of the difference may be due to hydrologic effects of cold water within aquifers in the plain, or deep circulating hot water along the boundary faults, or both. Brott et al. (1978) attribute the excess heat flow on the margin to refraction of heat into the higher thermal conductivity granites on the margins of the plain and suggest that this refracted excess heat is from buried basaltic intrusions that were emplaced 10-15 Myr ago.

Numerous thermal wells with water temperatures mostly less than $50^{\circ} \mathrm{C}$ are located throughout the western Snake River plain. Hot water $\left(>50^{\circ} \mathrm{C}\right)$ occurs in several springs and wells located along the margins of the plain. In both Boise and the Bruneau-Grand View area, these have been tapped for direct-use.

The area chosen for detailed HDR appraisal is a $400 \mathrm{~km}^{2}$ site on the northern margin of the western Snake River plain, Idaho (Fig. 18). Its western edge is approximately $10 \mathrm{~km}$ east of Mountain Home, and $23 \mathrm{~km}$ east of Mountain Home Air Force Base. This part of the northern plain margin was selected because it appeared to be less faulted than other sections of the margin. Two deep wells with gradients of $61^{\circ} \mathrm{C} / \mathrm{km}$ and $64^{\circ} \mathrm{C} / \mathrm{km}$ had been drilled in the area, and it had been reported that the Bostic $1 \mathrm{~A}$ well (Fig. 18), in the southern part of the prospect, bottomed in the granite of the Idaho batholith at $2941 \mathrm{~m}$ $\left(9648 \mathrm{ft}\right.$ ) with a bottom-hole temperature of $195^{\circ} \mathrm{C}$. It was discovered during 


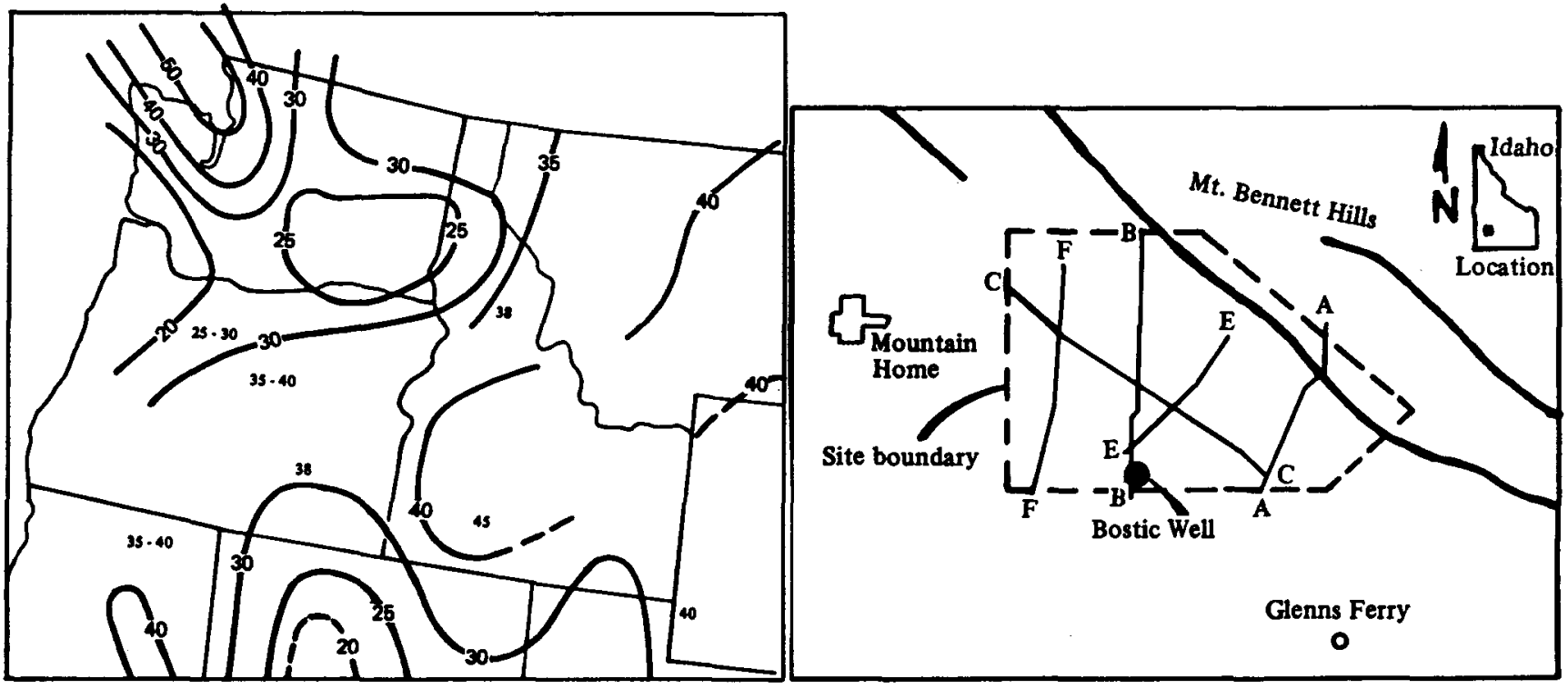

Fig. 17. Map of crustal thicknesses of western United States. Reprinted with permission of GSA.
Fig. 18. Location map of Mountain Home detailed study area showing geophysical survey lines and major faults.

the detailed evaluation that the hole actually bottomed in hydrothermally al tered latite, probably part of the Tertiary age Idavada volcanic sequence. The potential HDR "reservoir" target is that part of the Idaho batholith that extends beneath sedimentary and volcanic cover at the edge of the plain.

Harding Lawson Associates (HLA) of Novato, California, was awarded a contract to evaluate the HDR potential of the prospect. They performed geologic, geophysical, hydrologic, and water chemistry studies to determine the structure of the area, especially the location of faults and depth to basement, the permeability of the potential reservoir rock, and the thermal regime.

1. Geology and Structure. Most of the prospect lies within the Mountain Home plateau. The Mt. Bennett Hills form the northern and northeastern margin of the prospect and are separated from the western Snake River plain by northwest-trending faults that cut across the northeastern edge of the prospect. The geology southwest of the major fault zone consists of Tertiary and Quaternary age interbedded basalt flows and nonmarine sediments. In the Mt. Bennett Hills, older Tertiary Idavada (silicic) volcanic rocks are exposed. North of the Mt. Bennett Hills the Idaho batholith underlies the Idavada range (Rember and Bennett 1979, Malde et al. 1963). 
The predominant structure of the area is a set of northwest trending faults that form the northern boundary of the Snake River plain. More than $3000 \mathrm{~m}$ of total displacement, downthrown to the southwest, occurredalong this fault zone (Arney et al. 1980), during late Tertiary and early Quaternary time. There has been no apparent offset since middle Quaternary time (Malde 1959). Some faults are exposed in the Mt. Bennett Hills; others in the plain are sediment-covered and have been located by lineament analysis. Figure 19 shows a north-south cross section along the geophysical survey line B-B shown in Fig. 18.

2. Geophysics. A 500-station gravity survey disclosed a broad gravity low in the northwest corner of the prospect but failed to locate faults not exposed at the surface. Telluric profiling along three north-south lines indicates a resistivity low corresponding with the gravity low and suggests either deeper basin fill or extensive faulting, making this part of the prospect unsuitable as a HDR site. The rest of the area exhibits uniform resistivity at depth. Microseismic activity, recorded for 48 days, averaged less

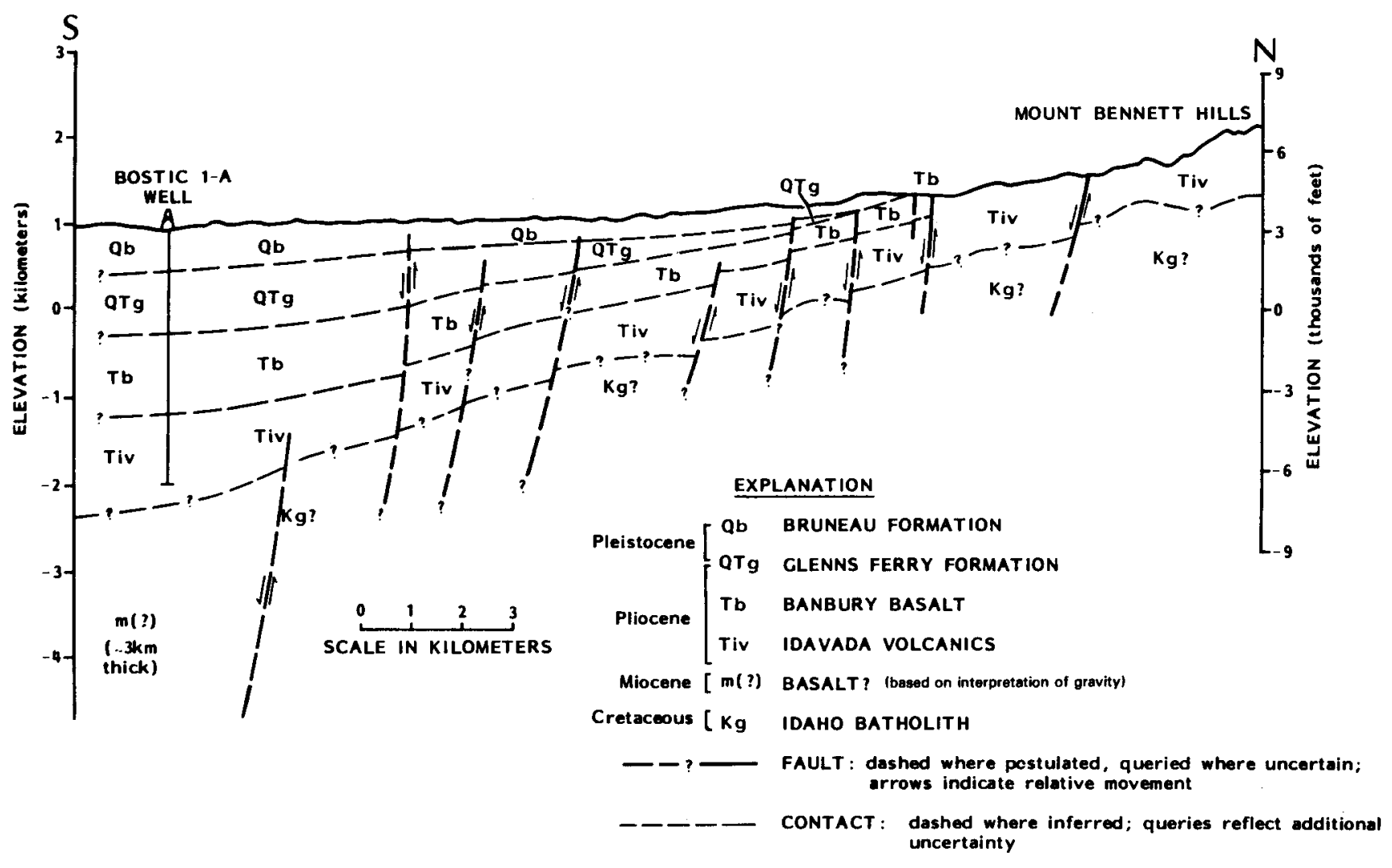

Fig. 19. Schematic geologic cross section and Bouguer gravity along line $\mathrm{B}-\mathrm{B}_{0}$. 
than one event per week within $25 \mathrm{~km}$ of the seismograph--a suitable seismic level for HDR development.

3. Hydrology and Water Chemistry. Small and perched aquifers occur in every geologic formation in the area in both intercalated sediments and fractured volcanic rocks. Hot springs emanate along two northwest-trending fault zones, one along the base of the Mt. Bennett Hills and one in the plain. Silica concentrations suggest equilibrium temperatures not much higher than 60 to $80^{\circ} \mathrm{C}$. Assuming that the Bostic gradient is representative, this suggests water circulation to only 750 - to $1000-\mathrm{m}$ depth; there appears to be no circulation to the surface from the 2- to 3-km-deep zone proposed for HDR development.

4. Conclusions. Based on gravity data and the Bostic 1A well cuttings, depth to Plutonic rocks in the southwestern portion of the prospect is greater than $3 \mathrm{~km}$. Gravity modeling done by Harding-Lawson suggests that the Idaho batholith may not underlie that part of the prospect at all. The exact location of faults and the amount of their displacement also needs to be determined to assess the HDR potential of the prospect.

Brothers Fault Zone, Oregon

The Brothers fault zone (Fig. 20) trends northwest-southeast across an area of Cenozoic volcanic fields in Southeast Oregon and coincides with a zone of high heat flow. Rhyolitic domes ranging in age from less than 1 to 10 Myr trend west-northwest, oblique to the fault zone. MacLeod et al. (1976) have shown that this silicic volcanism is generally younger to the west. The youngest published date is $0.58 \pm 0.1$ Myr for McKay Butte located on the west flank of Newberry Caldera.

Some of the highest measured temperature gradients along the fault zone are observed near the eastern domes, but they may be due to circulation of deep ground water along fault planes. The domes generally occur along faults or at intersections of older northeast-trending faults with the Brothers fault zone. The most recent known movement on the Brothers fault zone occurred 7-10 thousand years ago (G. Walker, USGS, personal communication), and the youngest domes do not appear to be faulted. Unfortunately, the younger domes have a smaller exposed surface area than the older faulted ones, and it is not known if they are larger or interconnected at depth; or if there are deeper intrusive bodies of low-permeability silicic rock suitable for HDR development. 


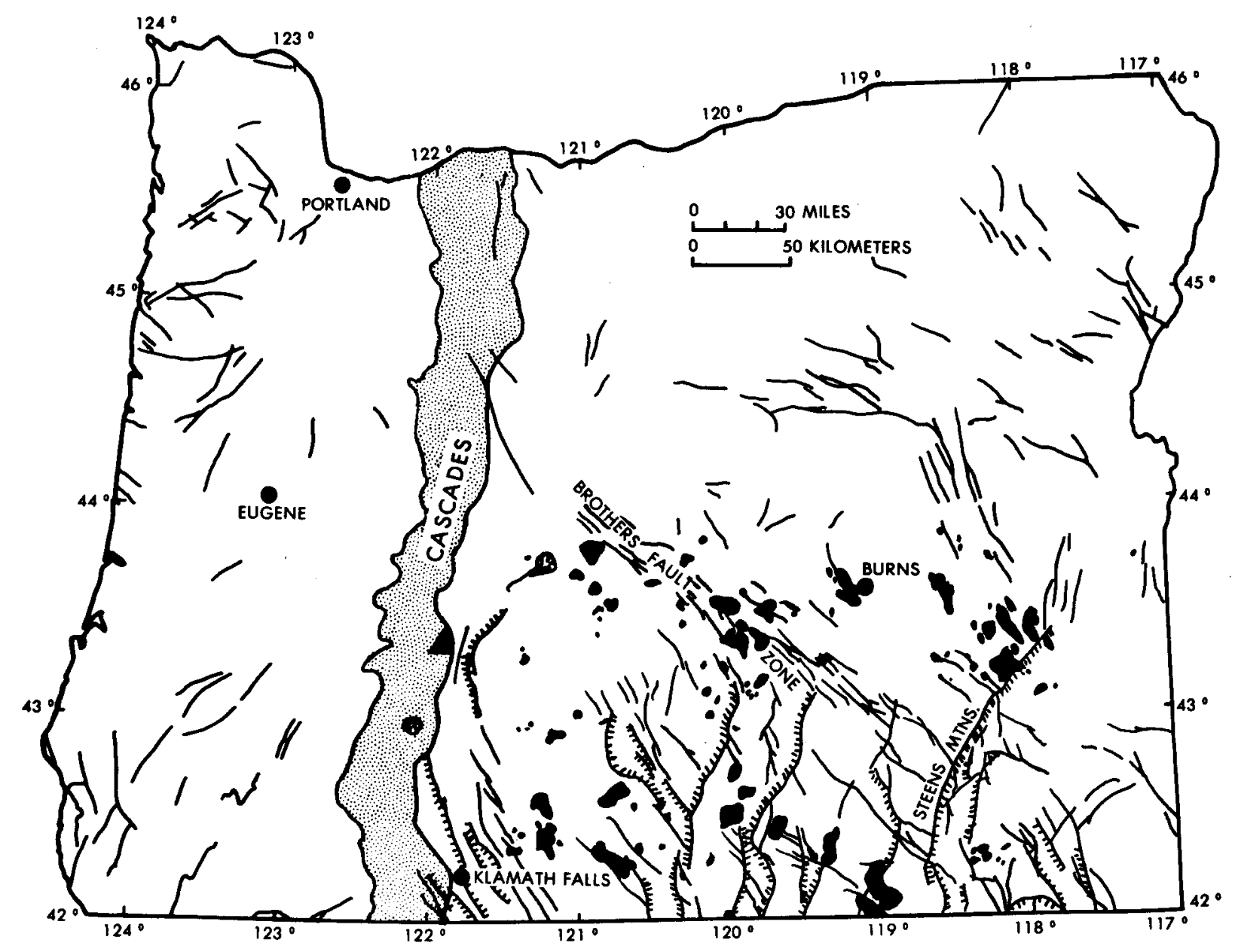

Fig. 20. Map of Oregon. Rhyolite domes in the southeastern part of the state are shown in black; strippled area is Cascade Range; hachures are shown on the down-thrown side of larger faults of the Basin and Range province. (from Macleod et a1. 1976.)

Little is known about what underlies the volcanic sequences in eastern Oregon. "Basement" is probably composed of Mesozoic marine sediments. Proprietary magnetic data suggest that considerable vertical displacement (down to the south) has taken place along the Brothers fault zone (G. Walker, USGS, personal communication 1980). A Halbouty well(Federal 1-10, 23S, 29E Sect. 10), drilled to $2343 \mathrm{~m}$ depth on the north side of the fault zone, bottomed in andesite. The base of the basalts was at $792 \mathrm{~m}$. On the south side of the fault zone the basalt sequence is probably much thicker.

The area selected for detailed study is on the east flank of Newberry Caldera. Two silicic domes of $3.5 \mathrm{~km}$ radius are adjacent to each other: 
China Hat (0.76 Myr) and East Butte (0.85 Myr). Samples of obsidians, collected to determine if the domes are petrogenically related suggest that they were not erupted from the same magma. A detailed gravity study of the dome area would show if a larger silicic body occurs at depth or if the two domes are interconnected--conditions which would provide a crystalline "reservoir rock" of sufficient volume for HDR development.

\section{H. Regional Summary}

The geologic setting in the northwest is one of Precambrian continental crust in much of Idaho and northern Washington and Oceanic crust of basalt and marine sediments, including an early Mesozoic volcanic arc, throughout the rest of Washington, Oregon, and northern California. Much of the region has been intruded by Mesozoic (mostly Cretaceous) granitic plutons, the largest of which is the Idaho batholith. Tertiary and Quaternary age volcanic activity has been extensive--from the stratovolcanoes of the Cascade Range to the flood basalts of the Columbia Plateau and Snake River plain, and has covered most of the older rocks obscuring geologic relationships. Significant Tertiary and Quaternary age silicic eruptions also occured in the region.

Heat flow generally reflects the tectonic setting. West of the Cascade Range heat flow is low and averages $35 \mathrm{~mW} / \mathrm{m}^{2}(0.85 \mathrm{HFU})$. The average heat flow for the western Cascade Range is $45 \mathrm{~mW} / \mathrm{m}^{2}(1.1 \mathrm{HFU})$. The high of 105 $\mathrm{mW} / \mathrm{m}^{2}(2.5 \mathrm{HFU})$ shown in Table $V$ for the Oregon Cascades is the average value given by Blackwell (1978) for the western Cascades-High Cascades boundary. This is a narrow zone of high heat flow beginning just west of the contact between the older western Cascades and the Pliocene-Pleistocene High Cascade volcanics. Several hot springs are located along this boundary. Few data are available for the high Cascades because of drilling difficulties and ground-water flow, but the recent volcanism suggests that high heat flow may continue across the range to the east. East of the Cascades heat flow is also high: southeastern Oregon averages $90 \mathrm{~mW} / \mathrm{m}^{2},(2.1 \mathrm{HFU})$ the margins of the western Snake River plain average $100 \mathrm{~mW} / \mathrm{m}^{2}(2.4 \mathrm{HFU})$ and the rest of the area averages above $71 \mathrm{~mW} / \mathrm{m}^{2}$ (1.2 HFU).

Seismic refraction studies show the crust is generally thinner than under cratonic regions, approximately $20 \mathrm{~km}$ on the coast thickening to $30 \mathrm{~km}$ under the Basin and Range province of Nevada. The crust appears to be thin under the Columbia Plateau but thickens under the western Snake River plain. 
The northwest U.S. has great geothermal potential, both for lowtemperature hydrothermal applications and hot dry rock for areas with no natural hot springs or aquifers. Hydrothermal waters have been used for space heating and industrial processing for years in both $\mathrm{K} /$ amath Falls, Oregon, and Boise, Idaho, and these applications are being expanded.

For most of the northwest, however, hot dry rock will not mean drilling into granitic rocks but rather fracturing or making use of natural fracture systems in low permeability basalts or metamorphosed marine sediments not containing enough hot water to be developed as hydrothermal systems. 
IV. SOUTHWEST: HEAT SOURCES IN ARIZONA, NEW MEXICO, AND THE TRANS-PECOS AREA OF TEXAS (M. J. Aldrich and A. W. Laughlin)

Arizona, New Mexico, and the Trans-Pecos area of west Texas include parts of five physiographic provinces: the Colorado Plateau, the Basin and Range, the southern Rocky Mountains, the Rio Grande rift, and the Great Plains (Fig. 21). A wide area between the Colorado Plateau and southern Basin and Range province has structural characteristics common to both provinces and, therefore, has been referred to as the "Transition Zone." In keeping with Fenneman's (1946) map, we include this segment of crust as a subsection of the Basin and Range province.

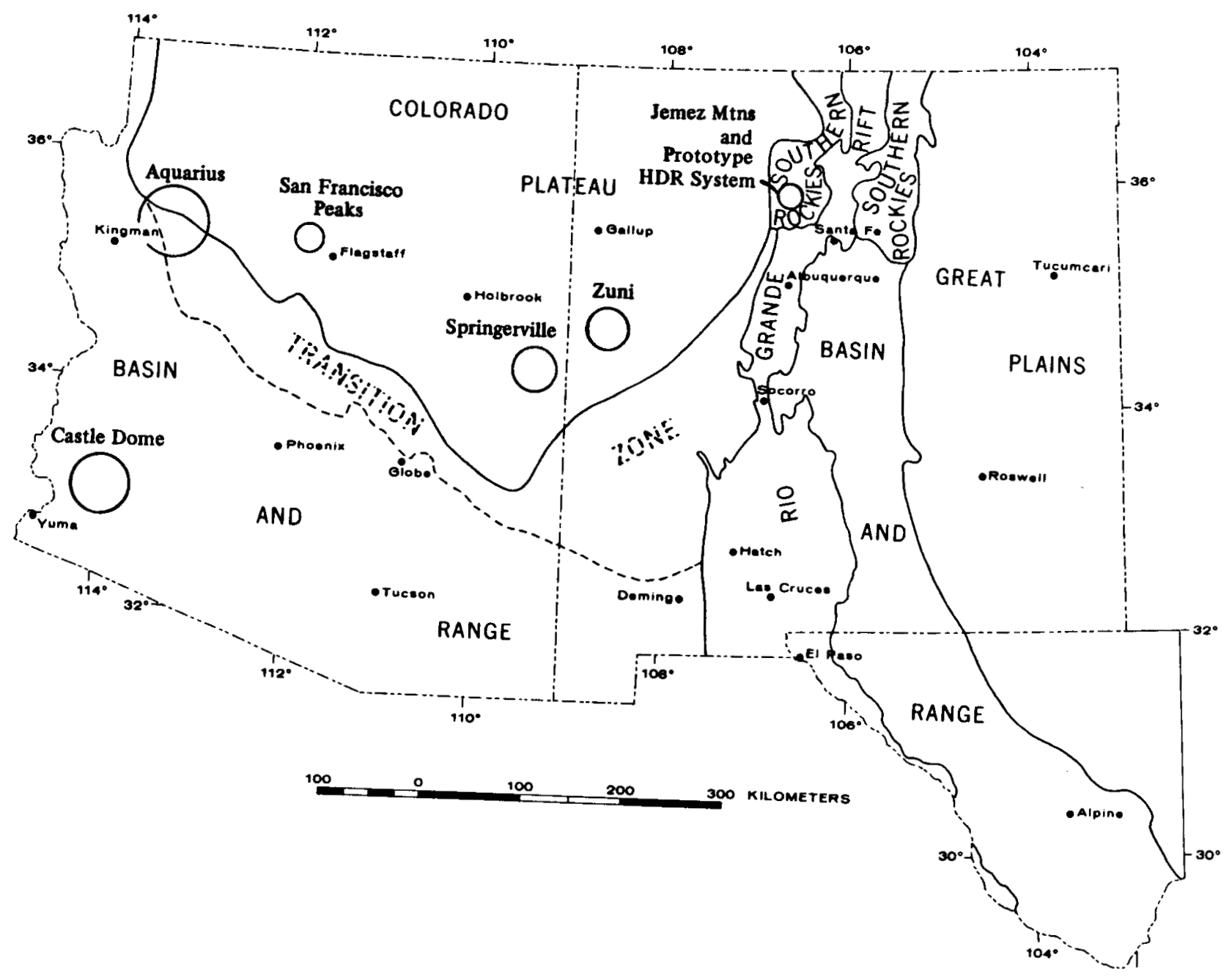

Fig. 21. Physiographic provinces of Arizona, New Mexico, and Trans-Pecos, Texas. 
Although high-temperature geothermal systems typically are developed around relatively small igneous (point) heat sources, large regions of high heat flow also have the potential for being developed as energy sources using HDR extraction technology. Both direct and indirect evidence indicates that regional as well as point igneous heat sources occur within the southwestern U.S. A number of the more obvious of these target areas have been recognized by the USGS in Circulars $\underline{726}$ and $\underline{790}$, and some have been designated as Known Geothermal Resource Areas (KGRA). The HDR Assessment Panel Report no. 1 contained descriptions of four areas in Arizona and New Mexico that seem to have HDR potential: the Jemez Mountains, New Mexico; San Francisco Peaks, Arizona; Zuni Mountains, New Mexico; and the area around Tucson, Arizona. In addition, Laboratory personnel have investigated the Aquarius Mountains and Castle Dome prospects in Arizona and Rio Grande rift prospects in New Mexico. Because the critical element in the definition of any geothermal system is the identification of a heat source, this report focuses on summarizing available data on both the regional and volcanic heat sources.

REGIONAL HEAT SOURCES

We have arbitrarily selected $\geq 83.5 \mathrm{~mW} / \mathrm{m}^{2}$ ( $>2 \mathrm{HFU}$ ) as the heat-flow value defining regions of high heat flow. Such heat flow, when combined with rocks of low thermal conductivity should yield geothermal gradients sufficiently high to be attractive HDR targets. In Arizona, considerable heat flow and gradient data are available and have most recently been summarized in map form by Shearer (1979). A simplified version of this map is presented in Fig. 22.

As Fig. 22 shows, of the 11 areas in Arizona with heat flow in excess of $\geq 83.5 \mathrm{~mW} / \mathrm{m}^{2}(>2 \mathrm{HFU})$, one lies on the Colorado Plateau near the town of Sanders in northeastern Arizona, and the remaining 10 are concentrated in the southern part of the state within the Basin and Range province. Byerly and Stolt (1977) present indirect evidence for the existence of probable elevated temperatures in the large region that borders the Colorado Plateau in northern Arizona. They have determined depths to the Curie point (approximately $500^{\circ} \mathrm{C}$ ) for the state of Arizona, finding shallow depths of less than $10 \mathrm{~km}$ for an area roughly coincident with the transition zone. Some depths were as shallow as $4 \mathrm{~km}$. If these values are approximately correct, the area has considerable 


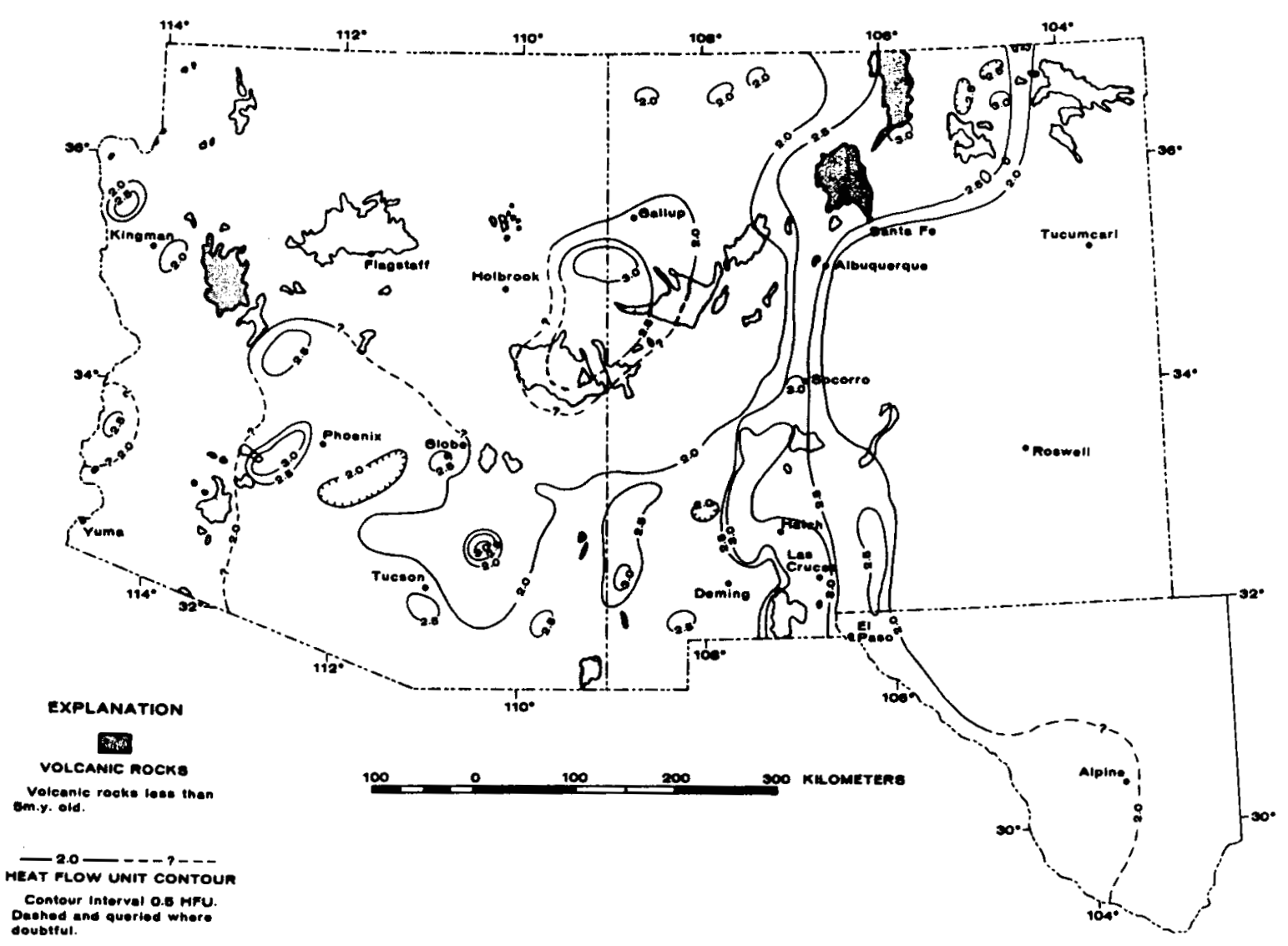

Fig. 22. Simplified revision of Shearer's (1979) map summarizing available heat flow and gradient data for Arizona, New Mexico, and West Texas.

HDR potential. Four of the ten areas in southern Arizona look like attractive prospects because the data (Fig. 22) are consistent, the anomalous region is large, and/or they are close to a large population center. These areas are central Pinal County between Tucson and Phoenix, eastern Pima County south of Tucson, western Pima County, and west-central Yuma County.

Los Alamos Laboratory staff and subcontractors examined two large areas in Arizona for HDR potential. The first of these, the Aquarius prospect (Goff et al. 1979; West and Laughlin 1979; Aiken and Ander 1980) in the northwestern corner of the state (Fig. 21), was initially located from a compilation of geophysical data that indirectly indicated probable high crustal temperatures. These data include a large gravity low that is coincident with a region of low 
seismicity, seismic wave delays, seismic P-wave attenuation, and shallow Curie point depths. Limited thermal gradient data seems to confirm the elevated temperatures. Magneto-telluric surveying, reconnaissance geologic mapping and aqueous geothermometry work in the area is summarized by Goff (1979) and Goff et al. (1979). This work indicates that the potential reservoir rock is Precambrian basement complex probably similar to that of the first HDR site at Fenton Hi11, New Mexico. A minimum temperature of $170^{\circ} \mathrm{C}$ at $4 \mathrm{~km}$ is estimated for this prospect (Goff et al. 1979).

The second potential site, the Castle Dome prospect in southwestern Arizona, was also initially chosen because of available geophysical data. A large gravity low appears to be coincident with high geothermal gradients reported by Shearer (1979). The Laboratory's work in magnetotelluric surveying, reconnaissance geologic mapping, and limited geochronological work is summarized in Gutmann et al. (1980) and Aiken and Ander (1980). They found that the most abundant basement rocks in the area are phyllites, quartzites, and metaconglomerates that resemble Mesozoic clastic rocks of the Dome Rock Mountains. These metamorphic rocks are overlain by a thick sequence of intermediate-to-silicic ash flow tuffs of mid-Tertiary age, perhaps representing a large caldera complex.

In New Mexico, heat-flow values above $83.5 \mathrm{~mW} / \mathrm{m}^{2}(2.0 \mathrm{HFU})$ form a more continuous pattern than in Arizona. As shown by Edwards et al. (1978), these high values are concentrated in two bands or regions. The largest of these is a band essentially coincident with the Rio Grande rift for the southern twothirds of the state and broadening out in the north to encompass the lateCenozoic volcanic fields in north-central and northeastern New Mexico. This broadening is thought to be related to the Jemez lineament crossing the rift at the Valles Caldera and continuing toward the northeast. The second region of high heat flow is in west-central New Mexico, approximately coincident with the Jemez lineament (Laughl in and West 1976).

For a number of reasons, the band along the Rio Grande rift probably has the highest potential for HDR. First, this band represents the largest area in the state with heat flow greater than $83.5 \mathrm{~mW} / \mathrm{m}^{2}$ (2 HFU). Second, some of the highest heat flow values are concentrated near the west side of the rift, particularly near young volcanic centers or at the intersections of 
cauldron boundaries with the rift. Reiter et al. (1975) reported heat-flow values in excess of $251 \mathrm{~mW} / \mathrm{m}^{2}(6.0 \mathrm{HFU})$ at four sites along the rift--the Jemez Mountains, Socorro Peak, San Diego Mountain, and Mirage. Third, sediments in the deep basins along the rift may serve as insulating blankets for the heat sources. Fourth, the major population centers of the state lie within the rift, providing users for the resource.

The Zuni Mountains area in west-central New Mexico also appears to have HDR potential. Heat flow values as high as $126 \mathrm{~mW} / \mathrm{m}^{2}$ ( $3 \mathrm{HFU}$ ) near Zuni Pueblo, at the approximate center of the area, were reported by Reiter et al. (1975). Late Cenozoic basaltic volcanism was common throughout the area, beginning about 3.8 Myr B.P., with major activity about 1.5 Myr B.P. (Laughlin et al. 1979). This activity continued until approximately 700 A.D. when the McCartys flow was erupted (Nichols 1946). Precambrian basement rocks, which may have low permeability because of extensive Laramide mineralization, crop out in the center of the Zuni Mountains and are only shallowly buried by Paleozoic sediments around the flanks of the mountains. Because of the coincidence of regionally high heat flow, young basaltic volcanism, potentially suitable reservoir rocks, and major users such as the towns of Grants and Gallup and the uranium mills and mines, Laughlin and West (1976) proposed this region for HDR development.

\section{B. Volcanic Heat Sources}

To evaluate the HDR potential of volcanic heat sources in Arizona, New Mexico, and Texas, we have used a maximum age of 3 Myr because residual igneous heat would have been dissipated since the extrusion of volcanic rock. No igneous rocks less than 3 Myr have been reported for the Trans-Pecos region of Texas, so that region will not be considered in this report.

A literature search for young igneous rocks revealed a large number with radiometric ages of less than 3 Myr from Arizona and New Mexico (Fig. 23). Within the southwestern U.S. the distribution of young igneous rocks shows a pattern controlled by the regional tectonic framework (Luedke and Smith 1978). Volcanism has been concentrated along the boundaries between physiographic provinces or along major cross-cutting structures such as the Jemez lineament. Both the province boundaries and the cross-cutting structures probably represent older zones of weakness in the basement that have been reactivated, sometimes repea tedly. 


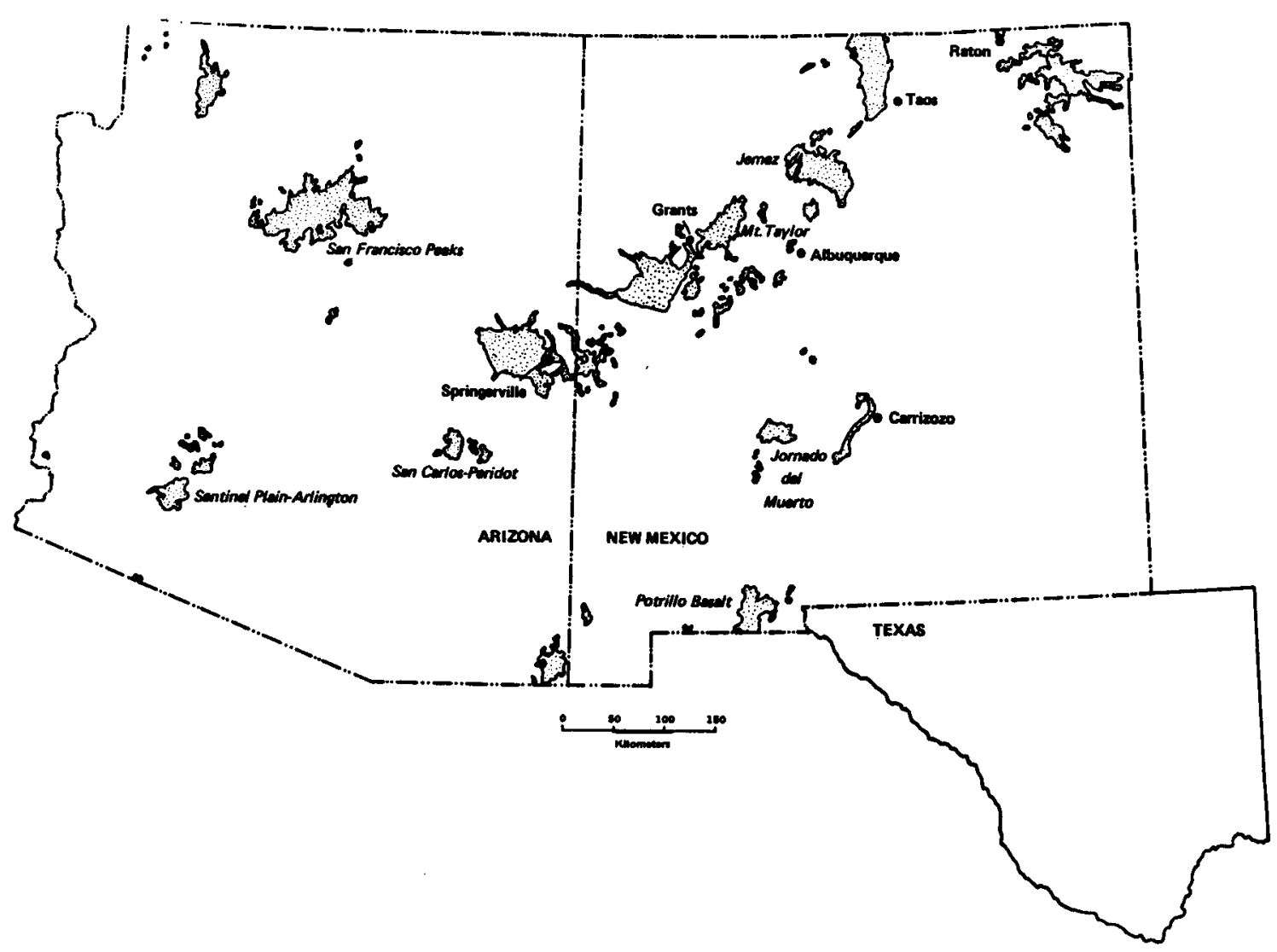

Fig. 23. Volcanic rocks <3 Myr in Arizona and New Mexico.

In Arizona, there are six areas with significant volumes of young volcanic rocks. In the northwestern corner of the state, a major basaltic volcanic field lies north of the Colorado River in Mohave County. Damon and coworkers have reported ages of 1.2 and $1.16 \mathrm{Myr}$ and approximately 10000 years for basalts in this field (Damon 1965 and 1966; Damon et al. 1967) 1ocated on the boundary between the Colorado Plateau and the Basin and Range province.

To the southeast, along the Colorado Plateau and Basin and Range boundary, the second major young volcanic field occurs near Flagstaff in the San Francisco Peaks area. Basaltic volcanism began here prior to 5 Myr B.P. and has continued essentially to the present (Sunset Crater, 1066 A.D.). Beginning about 4 Myr B.P., silicic volcanism occurred particularly along a northeasttrending structure passing through Bill Williams Mountain, Sitgreaves Mountain, and Kenrick Peak. A second chain of silicic centers developed post-2 Myr ago from Sitgreaves Mountain eastward to San Francisco Mountain and O'Leary Peak. 
Damon et a1. (1974) and McKee et al. (1974) have obtained K-Ar ages as young as 0.13 Myr on rhyolites from this eastern portion of the field.

Farther southeast, the next major volcanic field lies on the Jemez lineament near the towns of Springerville, St. Johns, and Show Low, Arizona. The activity here is probably an extension of the older White Mountains activity to the south. Merrill and Pewe (1977) report an age of 8.6 Myr for one of the later latite flows associated with the White Mountains activity. Basalts capping the high mesas south of Springerville have been dated by Laughlin et a1. (in press) at 6.03 Myr. Lower mesas are capped by basalts in the range 3.6-3.0 Myr, which in turn have been penetrated by vents with flows dated at 0.80-0.75 Myr (Laughlin et a1. 1979; Laughlin, in press).

A fourth young volcanic field, the Sentinel Plain-Arlington field, is located in southwestern Maricopa and eastern Yuma Counties; Volcanism here is all basaltic with K-Ar dates ranging from 4.2 to 1.28 Myr (Lee and Bell 1975; Euge et al. 1978; Shafiqullah et al. 1980; Shoustra et al. 1976; Eberly and Stanley 1978). According to Shafiquallah et al. (1980) there are 16 volcanic centers in the field associated with generally very thin lava flows.

East of Globe, Arizona, a large late-Cenozoic basaltic field, the San Carlos-Peridot field, is shown on the map of Luedke and Smith (1978) although no dates are reported. Shafiqullah et al. (1980) report a date of 0.93 Myr for the basalt of Peridot Mesa.

The San Bernardino volcanic field in southeastern Arizona and southwestern New Mexico is the only other major volcanic field in Arizona younger than 3 Myr. A small portion of this field extends south into Sonora, Mexico. The flows from this field are basanite in composition and contain abundant ultramafic xenoliths. Lynch (1978) and Marvin et al. (1978) report four K-Ar dates from the flows; these range from 3.30 to $0.274 \mathrm{Myr}$.

These six fields contain the largest volume of igneous rocks less than 3 Myr. Scattered small occurrences of young volcanic rocks do occur in other areas, but their geothermal potential is lower because of the area's limited eruptive activity.

In New Mexico, igneous rocks less than 3 Myr are concentrated in 10 major areas. These areas lie within the Rio Grande rift and along the Jemez 1 ineament.

The Springerville, Arizona, volcanic field discussed above is one of a number of volcanic fields that define the Jemez zone or volcanic lineament 
(Mayo 1958). That part of the lineament extending from the Arizona-New Mexico border near Springerville to Mt. Taylor and Mesa Chivato near Grants, New Mexico, has been volcanically active for at least 3.8 Myr (Laughlin, unpublished data). A large number of dates on basalts from this area span the range from 3.8 Myr to 700 A.D. (Laughlin et al. 1979; Bassett et al. 1963; Lipman and Mehnert 1975; Nichols 1946; and G. Heiken and J. C. Eichelberger, Los Alamos National Laboratory, unpublished data). Reiter et al. (1975) and Edwards et al. (1978) report heat flow values as high as $126 \mathrm{~mW} / \mathrm{m}^{2}$ (3 HFU) for this portion of the lineament and a broad zone in excess of $83.5 \mathrm{~mW} / \mathrm{m}^{2}$ (2 HFU) coincident with the lineament. Laughlin and West (1976) discuss the implications of the young volcanism and the high heat flow for the HDR potential of the area.

The San Bernardino volcanic field also discussed above extends into the southwestern corner of New Mexico. Five basaltic cones near Rodeo, New Mexico, are apparently a northeastern extension of this field. The Animas flow in Hidalgo County, recently dated by both the USGS and the University of Arizona (Marvin et al. 1978; Lynch 1978; Deal et al. 1978) with results ranging from $0.544 \pm 0.050$ to $0.14 \pm$ Myr, may also be part of the San Bernardino volcanic activity.

The Potrillo basalt field (Hoffer 1976) is a major late Cenozoic basaltic field straddling the New Mexico-Mexico border. The field has an area of approximately $1000 \mathrm{~km}^{2}$ and is made up of three volcanic centers--the West Potrillo Mountains, the Aden-Afar field, and the Santo Tomas-Black Mountain volcanic chain. Activity at the West Potrillo and Aden-Afar centers consisted of eruption of flows and the formation of cinder cones and maar volcanoes. At Santo Tomas-Black Mountain, the activity consisted of the eruption of basaltic flows and the formation of cinder cones. Luedke and Smith (1978) summarized the age determinations from a number of sources; these range from 2.26 Myr to 11080 yrs B.P.

North along the Rio Grande there are a number of young basaltic flows north of Truth or Consequences. The largest of these is the Jornada del Muerto flow on the east side of the river. This flow has been dated at 0.76 Myr by Bachman and Mehnert (1978).

Near the town of Carrizozo there are two basalt flows, the Carrizozo and the Broken Back Crater flows, that are thought to be younger than 3 Myr on the basis of geologic evidence. Allen (1951) estimates the age of the younger of 
these (the Carrizozo) as 0.001 Myr. Renault (1970) and Aoki and Kudo (1978) report that these flows are alkali-rich but hyperthene-normative.

West of Albuquerque between the Zuni Mountains and the Rio Grande rift is a group of basaltic flows that, in part, have received little attention. The group includes, on the east, the cones and flows of the Albuquerque volcanoes (0.19 Myr, Bachman et al. 1975); the Los Lunas volcano (1.31-1.01 Myr, Bachman et a1. 1975); the Isleta volcano; Cerro Tome (3.4 Myr, Bachman and Mehnert 1978); Mesa Carrizo (3.7 Myr, Bachman and Mehnert 1978); and Mesa del Oro (3.1 Myr, Bachman and Mehnert 1978). A number of other flows to the west have not been dated.

A large, complex volcanic center lies within and around the Jemez Mountains at the intersection of the Jemez lineament and the Rio Grande rift. This center includes the volcanic rocks of the Jemez Mountains and the basalts of the Cerros del Rio and Santa Ana mesa. The eruption ages for this area are summarized by Luedke and Smith (1978) to present a history of volcanic activity extending from 10.4 Myr to 0.434 Myr. Marvin and Dobson (1979) report a still younger age of $0.13 \mathrm{Myr}$ for the Banco Bonito flow. The geology of this region has been described by Smith and Bailey (1968), Smith et al. (1970), Doell et a1. (1968), and Aubele (1978). Laughlin (1981) has reviewed the locat and regional geology and its relation to the development of the various geothermal systems in the area. Although volcanic activity began about 10.4 Myr ago, the geothermal systems currently under development by Union $0 i l \mathrm{Co}$. and the Laboratory are presumably related to the igneous events associated with the eruption of the two members of the Bandelier Tuff at 1.4 and 1.1 Myr B.P. (Doell et a1. 1968). This unit is the largest volume of young (<3 Myr) silicic tuff in New Mexico (and the Southwest) and, as such, is probably the most important igneous heat source in the state. Brook (1979) estimates the hydrothermal resource alone for the Valles Caldera to be $87 \times 10^{18} \mathrm{~J}$. The total resource base of the Valles Caldera, estimated by Smith and Shaw (1979), is $8425 \times 10^{18} \mathrm{~J}$; much of this is likely to be in the form of HDR.

Aoki (1976), Lipman (1969), Lipman and Mehnert (1979), Manley (1978), and Ozima et al. (1967) have described the volcanic rocks of the Taos Plateau in northern New Mexico. These rocks, covering about $1500 \mathrm{~km}^{2}$ of the Rio Grande rift, are predominantly basaltic but minor andesite, rhyodacite, quartz latite, and rhyolite occur. Lipman and Mehnert (1979) attribute formation of 
the quartz latites, and rhyolites to low-pressure fractional crystallization. The volcanism within the Taos plateau extended from about 4 Myr to 2 Myr (Lipman and Mehnert 1979; Manley 1978; and Ozima et a1. 1967) with the more silicic rocks falling within the same time span as the basalts.

Two separate late-Cenozoic volcanic fields are located on the High Plains of northeastern New Mexico in Mora County and in the Raton-Clayton area. These fields were described by Lee (1922), Collins (1949), Baldwin and Muehlberger (1959), Bachman (1953), and Stormer (1972a and b). The Mora County volcanic field is made up of alkali olivine basalts ranging in age from 4.7 to 3.3 Myr (Hussey 1971; Stormer 1972a) while in the Raton-Clayton rocks field, a more complex suite of volcanic rocks occurs. The Raton-Clayton rocks range in composition from alkali olivine basalts to andesites and dacites and in age from 8.2 Myr to 10 000-4000 years (the Capulin basalts) (Stormer 1972a; Baldwin and Mueh1berger 1959). Edwards et a1. (1978) report high heat-flow values for at least part of the area covered by these fields.

\section{Potential Reservoir Rocks}

A compilation of all available basement rock data for the region is in progress. This includes age, lithology, depth, and orientation of major structures. Within the southwestern U.S. the basement rocks are mainly Precambrian age, although Laramide and mid-Tertiary plutons and gneissic complexes may in some instances be suitable HDR reservoirs. Stress field orientation data are also being compiled to permit estimates of the orientation of induced fractures. These data will be summarized in subsequent reports.

\section{CONCLUSIONS}

The southwestern U.S. has high HDR potential because of numerous large areas of high heat flow, i.e., much of the Basin and Range province and the Rio Grande rift and the numerous young volcanic centers. Basaltic centers are common and, although young silicic centers are less abundant, several large ones occur within the region. Deep penetrating geophysical surveys indicate that relatively shallow magma chambers may also occur at several sites, particularly along the Rio Grande rift. Young silicic centers such as the Valles Caldera, San Francisco Peaks area, and Mt. Taylor may be considered the high grade resources of the region whereas the large areas of high heat flow make up a lower-grade resource base. 
V. HDR GEOTHERMAL POTENTIAL IN THE ROCKY MOUNTAIN STATES OF COLORADO, WYOMING, AND MONTANA (Andrea C. Eddy)

A. Geomorphic Provinces

The Rocky Mountain states of Colorado, Wyoming, and Montana (Fig. 24), include parts of six geomorphic provinces, representing a variety of geologic settings. The Rocky Mountains extend through all three states, interrupted by the Wyoming Basin. They are commonly subdivided into three separate provinces, the Northern, Middle, and Southern Rockies (Mallory et al. 1972). The divisions nearly correspond to state boundaries, therefore they are also referred to as the Montana, Wyoming, and Colorado-New Mexico Rockies. To the east of the Rocky Mountains, the Great Plains Province is continuous through all three states. The eastern margin of the Colorado Plateau occupies the part of Colorado that is west of the Rocky Mountains.

The Montana Rockies consist of late Tertiary fault-bounded basin-andrange-type mountains, frontal ranges bordered by Laramide thrust-faults and an eastern, highly deformed, Laramide "Disturbed Belt." Geosynclinal Precambrian Belt-series rocks appear in the uplifted cores of the mountains, which are flanked by thick Paleozoic sedimentary deposits. Cretaceous age igneous activity formed large complexes such as the Boulder Batholith - Elkhorn Mountain Volcanics (Tilling 1973). Minor igneous activity continued into Tertiary time (Eocene) forming satellite plutons, such as those to the Bitterroot dome of the Idaho Batholith (Hyndman 1979) and post batholith volcanics such as the Lowland Creek Volcanic sequence (Tilling 1973). It has been suggested that the Boulder Batholith, and Idaho Batholith may be related or connected (Hyndman 1979).

The "Northern Intermountain Seismic Belt" extends through the Northern Rocky Mountains northwestward from Yellowstone, approximately parallel to the Idaho-Montana border (Smith 1978; Sass et al. 1980). Earthquake focal depths of 5 to $10 \mathrm{~km}$ predominate, with the most intense activity occurring in the west Yellowstone area. Crustal thickness under the Rocky Mountains in Montana is 35 to $40 \mathrm{~km}$, thickening toward the east (Smith 1978).

The Middle Rockies extend from the Beartooth Mountains of southern Montana through Wyoming and include the Uinta Mountains of northern Utah and northwestern Colorado. The Uinta Mountains are separated from the rest of the province by the Wyoming Basin (Mallory et al. 1972). The east-west trend of the Uintas is anomalous in the north-west trending province. 


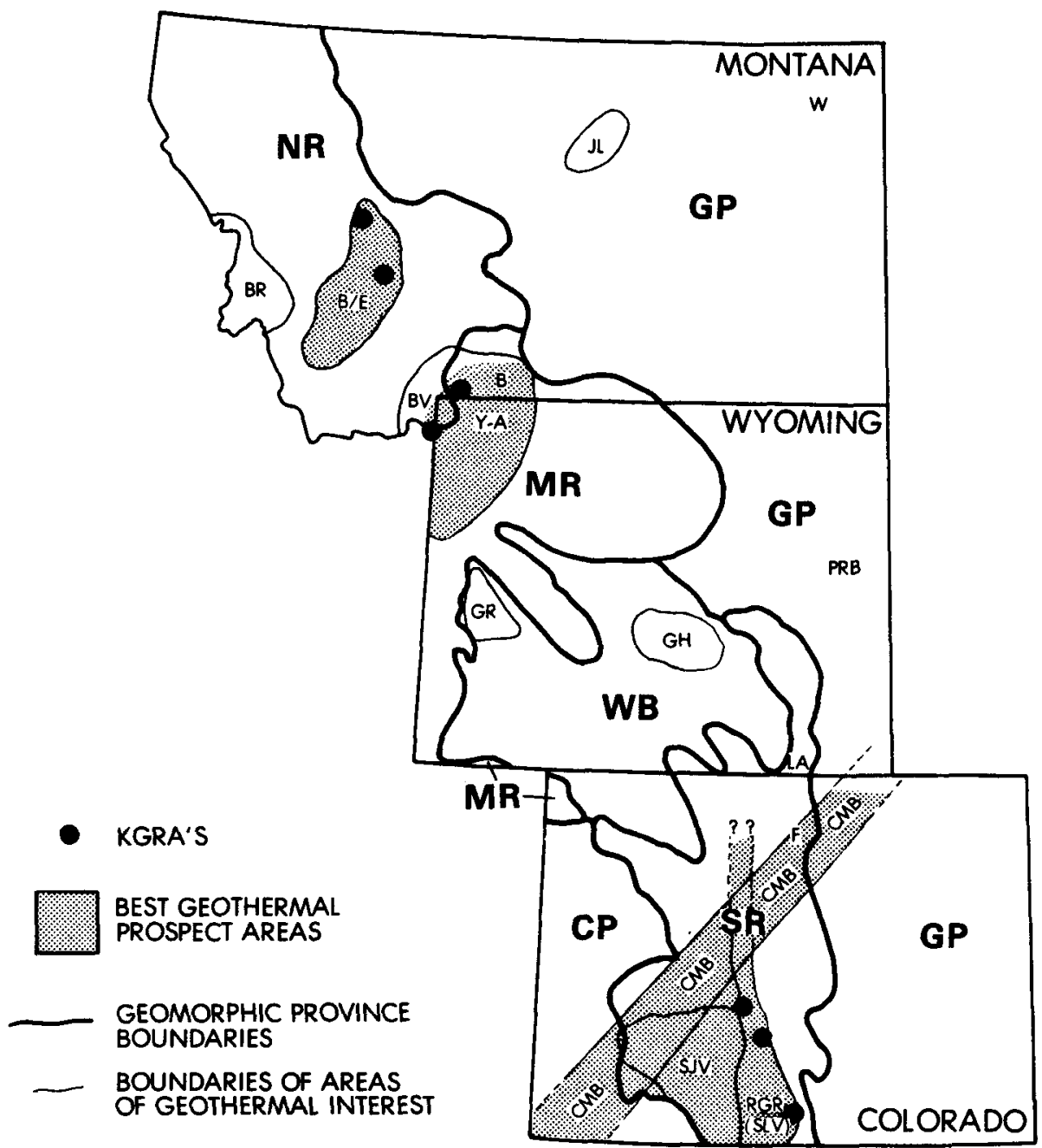

Fig. 24.

Geomorphic provinces and areas of geothermal interest. Abbreviations (alphabetized): $B=$ Beartooth Mts., $B-E=$ Boulder Batholith/Elkhorn Mts. Volcanics complex (Marysville-Helena-Butte area), Hills, $B R=$ Bitterroot Range, $B V=$ Beaverhead-West Yellowstone, Upper Yellowstone River basin, $C M B=$ Colorado Mineral Belt, $F=$ Front Range, $G H=$ Gas Hills area, $G R=$ Green River Basin geopressurized area, $J L=$ Judith Mts. /Little Rockies, LA = Laramie Mts., PRB = Powder River Basin, RGR = Rio Grande Rift, SJV = San Juan Volcanics, SLV = San Luis Valley, $W=W i l l i$ ston Basin, $Y-A=$ Yellowstone/Absaroka area.

Note: Not all areas discussed in text are shown. Boundaries after Mallory et al. 1972. 
The Middle or Wyoming Rockies are characterized by vertical uplifts and extensional, basin-and-range structural features. On the east, anticlinal or domal uplifts have Precambrian plutonic and metamorphic cores flanked by Paleozoic and Mesozoic rocks. On the west, the ranges were formed by erosion of thrust-faulted terrain with large horizontal displacements. The Yellowstone plateau is underlain by thick sequences of young, silicic, and intermediate volcanic rocks, with insignificant topographic relief. In contrast, the Absaroka Mountains to the east are a deeply dissected pile of older (early Tertiary) pyroclastics and flows of intermediate composition.

The Wyoming Basin is actually a collection of basins separated by uplifts. Familiar names included in the province are the Green River Basin in the southwest and the Wind River Basin in the northeast. The thick Tertiary basin fill is separated by partly exhumed mountains of older rocks and by Cenozoic-age laccoliths.

The Southern Rockies of Colorado are characterized by en echelon anticlinal ranges with exposed cores of Precambrian igneous and metamorphic rocks, separated by intermontane basins filled with Cenozoic sediments. Some of the mountains are flanked by Cenozoic volcanic rocks and intrusions. Paleozoic sequences of limestone and shale overlie the Precambrian in some areas. As in parts of the Northern Rockies, the eastern front of the Colorado Rockies is an abrupt topographic escarpment.

The San Luis and upper Arkansas valleys are deep, fault-bounded, sedimentary basins forming the northern extensions of the Rio Grande rift, a major crustal rift zone that extends south through New Mexico, Texas, and into northern Mexico. The extensive Cenozoic San Juan volcanic field of southwestern colorado includes many calderas, and is believed to overlie a major batholith.

The eastern margin of the Colorado Plateau consists of horizontal to gently dipping sediments, locally faulted and folded. Major high-angle faults and monoclines bound the basins and uplifts. In places, salt domes and igneous intrusions cut the sediments. Cenozoic volcanic fields and small Precambrian exposures occur locally.

The Great Plains are underlain by deep basins filled with Mesozoic and Cenozoic sedimentary rocks (e.g., Williston, Powder River, and Denver Basins). Some are interbedded with minor Cenozoic volcanic and intrusive rocks. Depths to crystalline basement rocks vary from 500 to $2200 \mathrm{~m}$ in central Montana and 
eastern Colorado, and reach $5000 \mathrm{~m}$ or more in the Williston and Powder River Basins of the northeastern parts of Montana and Wyoming.

B. Thermal Regime

Regional thermal gradient and heat-flow maps for the Rocky Mountain states are shown in Figs. 25 and 26. Localized anomalies caused by hydrologic convection are not shown. A comparison with the Cenozoic volcanic distribution map, Fig. 26 shows that heat flow values over $105 \mathrm{~mW} / \mathrm{m}^{2}$ (2.5 HFU) correspond closely to areas of recent (<6 Myr) volcanism, specifically the Yellowstone area and the San Juan volcanic field. Most of the rest of the Rocky Mountain province has heat flow of between 63 to $105 \mathrm{~mW} / \mathrm{m}^{2}(1.5$ and 2.5 HFU). The Great Plains of Montana, most of the Wyoming Basin, and the northeastern margin of the Colorado Plateau are all generally less than 63 $\mathrm{mW} / \mathrm{m}^{2}$ (1.5 HFU).

Heat flow outside the volcanic areas is primarily influenced by tectonic factors. The northern Rocky Mountains (Montana) are part of Blackwell's (1969; 1978) "Cordilleran thermal anomaly zone." The high heat flow (>63 $\mathrm{mW} / \mathrm{m}^{2}$ ) is thought to be related to subduction during Mesozoic and Tertiary time, which resulted in igneous intrusive activity, back arc volcanism, and extension (see section on northwest United States for more detailed discussion). Heat flow in the Colorado Rockies may be controlled by major zones of weakness in the crust, some related to Precambrian structures, along which there has been more recent movement, extension, volcanic, and/or hydrothermal activity.

Thermal gradients are slightly above normal $\left(>30^{\circ} \mathrm{C} / \mathrm{km}\right)$ over broad areas and abnormally high in some (Kron and Heiken 1980; Guffanti and Nathenson 1980). Active hydrothermal areas tend to be associated with negative gravity anomalies and generally with young intrusive and extrusive igneous rocks, intersections of major structural lineaments, areas of high seismicity, young tectonism, and high heat flow.

C. Geothermal Potential (by Province).

1. Northern Rockies. Heat flow in the Montana Rockies is relatively homogeneous and moderately high at 75 to $79 \mathrm{~mW} / \mathrm{m}^{2}$ (1.8 to $\left.1.9 \mathrm{HFU}\right)$. After removal of crustal heat production, mantle-heat flow is apparently about 59 $\mathrm{mW} / \mathrm{m}^{2}$ (1.4 HFU) (Sass et al. 1980). 


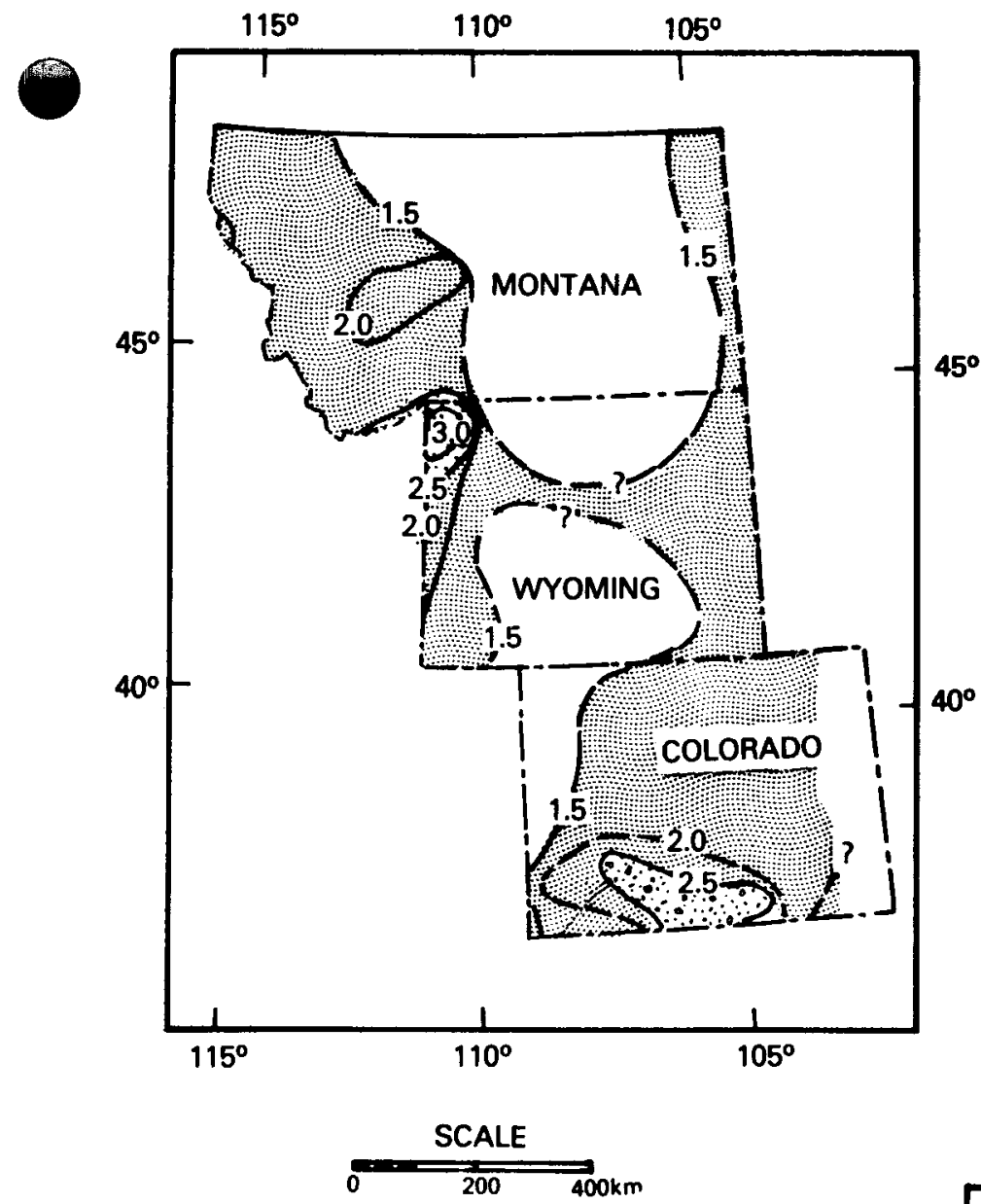

Fig. 25.

Revised heat-flow map (from Blackwell $45^{\circ}$ 1978). Contours are in heat-flow units.

Fig. 26.

Areal distribution and age range (see key to patterns) of Cenozoic volcanism in the western U.S. Areas of no large-scale Cenozoic volcanism are blank (from Blackwell 1978).

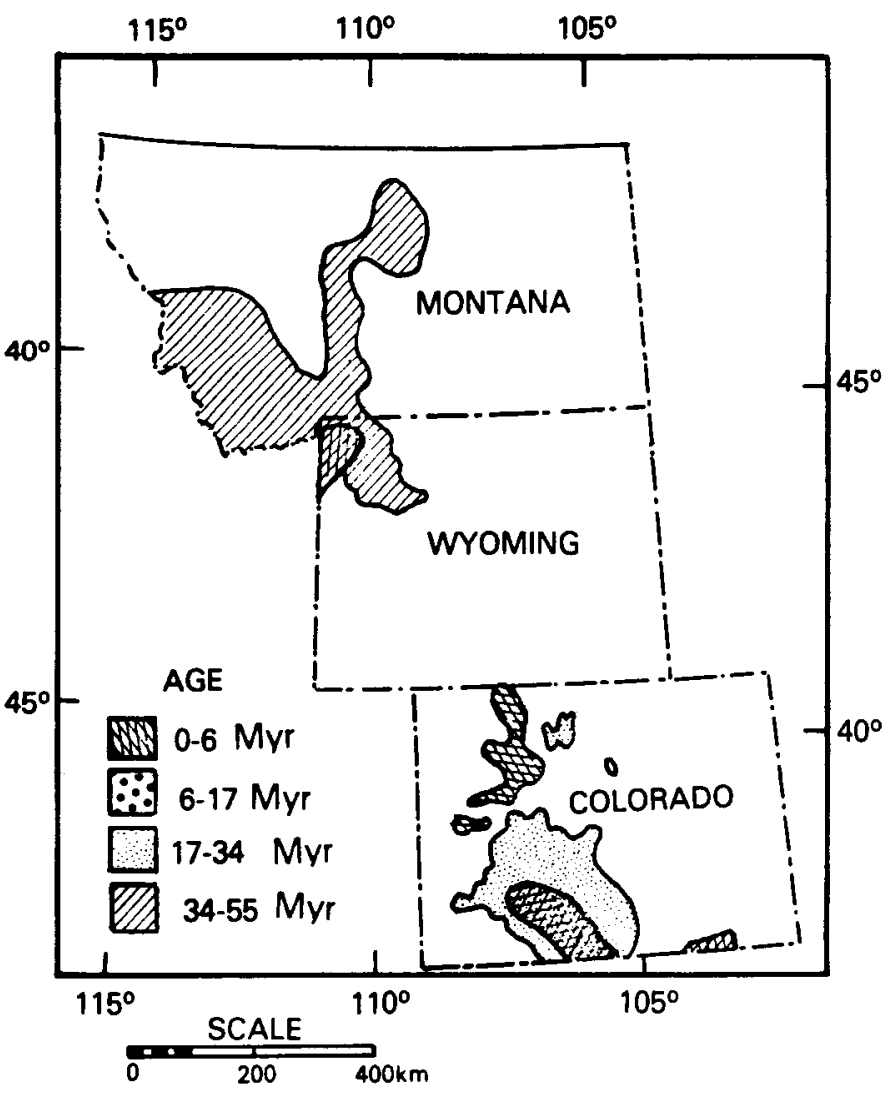


The Montana Rocky Mountains are generally less recently volcanic and tectonically active than the rest of the range. Described as a Mesozoic volcanic arc/geosynclinal environment (Burchfiel 1980), this province has only limited Cenozoic volcanism and plutonism.

Although no extensive hydrothermal areas have been located in the Montana Rockies, several hydrothermal systems are associated with faults and late Mesozoic age intrusions in the Northern Intermountain Seismic Belt. These hydrothermal convection systems generally are shallow, small, and isolated, with reservoir temperatures $\left(\mathrm{T}_{\mathrm{SiO2}}\right)$ mostly in the range of 85 to $160^{\circ} \mathrm{C}$ (Robertson et a1. 1975). Most geothermal activity centers around the Boulder batholith/Elkhorn Mountains volcanic complex in the Helena-Butte area (around Warm Springs, Radersburg), and includes the Marysville and Boulder Hot Springs KGRA's (Muffler 1979). The Boulder batholith is characterized by low regional Bouguer gravity (<-200 milligals) (Biehler and Bonini 1968) and a prominent magnetic high (Mabey et al. 1978).

The Marysville thermal anomaly, located $30 \mathrm{~km}$ northwest of Helena, Montana, was identified by its high heat flow, 130 to $380 \mathrm{~mW} / \mathrm{m}^{2}(3.1$ to 9.1 HFU) (Blackwell 1974). The lack of surface expression of a hydrothermal system led to the assumption that the high heat flux was due to a shallow magma body. However, a deep production well ( $\sim 2 \mathrm{~km})$ penetrated a hydrothermal zone from $610 \mathrm{~m}$ to $2070 \mathrm{~m}$ with a temperature of $93^{\circ} \mathrm{C}$ (HDRAP 1977).

other areas of low-temperature geothermal interest are white sulphur Springs $\left(150^{\circ} \mathrm{C}\right)$ (White and Williams 1975), the Lolo Valley (Lolo Hot Spring), the Crazy Mountains Basin/upper Yellowstone River Valley area, the Beaverhead-West Yellowstone area, and the Bitterroot Range south of Missoula. Areas most promising for HDR development are near the margins of larger $(>5 \mathrm{~km}$ radius) plutons.

Magnetic highs are characteristic of many Cretaceous and Tertiary age plutons and volcanic fields in western Montana and may be useful in locating buried intrusive bodies (Mabey et al. 1978) suitable as HDR "reservoirs." Middle Rockies

The Middle Rockies as defined here include the Yellowstone-Plateau-Island Park Caldera region (Montana/Wyoming). This is the area of youngest volcanism associated with the Snake River Plain "hot spot." Within Yellowstone Park, heat flow is $\geq 105 \mathrm{~mW} / \mathrm{m}^{2}$ everywhere, and mostly 251 to $418 \mathrm{~mW} / \mathrm{m}^{2}(\geq 2.5,6$ to 10 HFU). Locally, heat flow is as much as $2090 \mathrm{~mW} / \mathrm{m}^{2}$ (50 HFU). In the calderas 
heat flow is characterized by surface water temperatures of $74^{\circ}$ to $95^{\circ} \mathrm{C}$ and subsurface (calculated and observed) temperatures of $73^{\circ}$ to $421^{\circ} \mathrm{C}$ (Sass et al. 1980; Muffler 1979). Possessing the highest thermal energy of any system in the U.S., only 3.5\% of the potential is currently identified hydrothermal (mostly hot water, though locally vapor-dominated) (Brook et al. 1979). The rest is defined as magma and hot dry rock. As a national park, the Yellowstone caldera complex is withdrawn from exploration and development, but tectonically and hydrothermally active areas to the north, west, and south show geothermal potential. These areas include Huckleberry Hot Spring in Wyoming $\left(150^{\circ} \mathrm{C}\right.$ reservoir, Muffler 1979$)$ and Yellowstone and Corwin Springs KGRAs in Montana.

The Absaroka Mountains form the eastern boundary of the Yellowstone Plateau. They consist of Cretaceous to mid-Tertiary age volcanics that have been uplifted and dissected by erosion. Heat-flow values average $75 \mathrm{~mW} / \mathrm{m}^{2}$ (1. $8 \mathrm{HFU})$,* considerably lower than in the younger Yellowstone volcanics.

Outside the Yellowstone-Absaroka volcanic region, heat flow in the

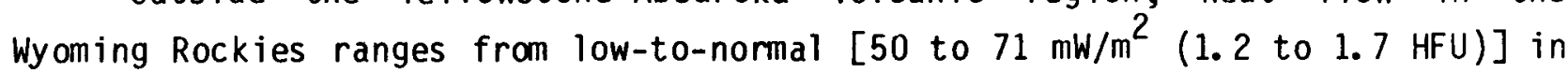
the northeast part to moderate-to-high in the central and southwest parts (Sass et al. 1980; Muffler 1979). This includes an east-west band of $63 \mathrm{~mW} / \mathrm{m}^{2}$ ( $>1.5 \mathrm{HFU}$ ) across north-central Wyoming, which extends on beneath the Great Plains. Thermal gradients exceed $30^{\circ} \mathrm{C} / \mathrm{km}$ throughout most of the province (Kron and Heiken 1980). Low-temperature geothermal systems are common in the Wyoming Rockies, but few (except Yellowstone) are $\geq 90^{\circ} \mathrm{C}$.

Other areas in the Wyoming Rockies that exhibit both hydrothermal and HDR geothermal potential, include the upper Yellowstone Valley, the Beartooth Mountains, the Precambrian terrane near Cody, Wyoming, the Bighorn Mountains, the Bridger-Teton Range (southeast of Grand Teton National Park), and Thermopolis and the Bridger Mountains (Owl Creek) area.* The entire Overthrust Belt may be another possibility* because of its probable high heat flow, gravity low, and $150^{\circ} \mathrm{C}$-reservoir at Auburn Hot Springs (White and Williams 1975). Most of these areas are in regions of moderate to relatively high seismicity (Mallory et al. 1972).

3. Wyoming Basin. The Wyoming Basin has fairly continuous low-to-normal heat flow from the Laramie Mountains westward. On the western edge of the *E. R. Decker, Los Alamos National Laboratory, personal communication, 1980. $\star \star D$. Foley, University of Utah, personal communication, 1980. 
Wyoming Basin, heat flow and thermal gradients are probably above normal, perhaps because of a geopressurized area in the northern Green River Basin.** The low-to-normal heat flow characterizing the province [average 54 to 67 $\mathrm{mW} / \mathrm{m}^{2}$ (1.3 to $1.6 \mathrm{HFU}$ ), Sass et al. 1980] is a product of long-term tectonic stability, low thermal conductivity mantle, and low regional thermal flux. Seismic activity is moderate-to-nonexistent. There are low-temperature geothermal systems throughout the Wyoming Basin, but few exceed $90^{\circ} \mathrm{C}$; thermal gradients and heat flow are mostly below continental averages $\left[<30^{\circ} \mathrm{C} / \mathrm{km},<63\right.$ $\left.\mathrm{mW} / \mathrm{m}^{2} \quad(<1.5 \mathrm{HFU})\right]$ except for the Green River Basin (and Moxa Arch to the southwest), where 63 to $71 \mathrm{~mW} / \mathrm{m}^{2}(1.5$ to $1.7 \mathrm{HFU}$ ) is reported (Sass et al. 1976).

Hot spring activity is limited to the north-central Wyoming Basin, generally around the Gas Hills area, where heat flows up to $145 \mathrm{~mW} / \mathrm{m}^{2}$ (up to 3.5 HFU) are reported, although the average is $79 \mathrm{~mW} / \mathrm{m}^{2}(1.9 \mathrm{HFU})$. * Mid-Tertiary volcanic fields (Rattlesnake Hills) and exposed Precambrian rocks are found in the Gas Hills area. The Leucite Hills comprise the only other Tertiary volcanic field in the Wyoming Basin; no surface thermal phenomena are found, but gravity and heat-flow data may indicate low-temperature geothermal potential.*,$* \star$

Most of the Wyoming Basin is characterized by negative Bouguer gravity, which is also reflected in negative Airy-Heiskanen isostasy (Woollard 1966).

4. Southern Rockies. The Rocky Mountains in Colorado exhibit multiple criteria favorable for geothermal potential; Late Cenozoic age volcanism, extensional rifting and normal faulting, deep sediment-filled grabens, deeply circulating thermal waters and unusually high heat flow (crustal radiogenic, as well as mantle).

The "Southern Rocky Mountains Complex thermal anomaly" (Reiter et al. 1979b) is centered on the Rio Grande rift, which extends into Colorado from New Mexico. Its thermal width in southern Colorado is difficult to determine because of the high thermal flux in the San Juan volcanic field to the west $\left[88\right.$ to $105 \mathrm{~mW} / \mathrm{m}^{2}(2.1$ to $\left.\geq 2.5 \mathrm{HFU})\right]$ and high heat flow $\left[84\right.$ to $105 \mathrm{~mW} / \mathrm{m}^{2}$ (2 to $\geq 2.5 \mathrm{HFU})]$ in the Raton Basin east of the main rift. Heat flow of 67 to 88 $\mathrm{mW} / \mathrm{m}^{2}$ (1.6 to $2.1 \mathrm{HFU}$ ) is reported for the Arkansas Valley and $105 \mathrm{~mW} / \mathrm{m}^{2}(>2.5$ HFU) for the San Luis Valley, which are the two fault-bounded grabens that

* E. R. Decker, Los Alamos National Laboratory, personal communication, 1980. $\star \star D$. Foley, University of Utah, personal communication, 1980. 
Adefine the Rio Grande rift in Colorado. The Rio Grande rift is generally Considered to terminate in the Leadville area $\left[105 \mathrm{~mW} / \mathrm{m}^{2}(2.5 \mathrm{HFU})\right]$ but related block faulting extends northward to the Wyoming border (Tweto 1979). In the Park Ranges in north-central Colorado, heat flows are 88 to $100 \mathrm{~mW} / \mathrm{m}^{2}$ (2.1 to 2. $4 \mathrm{HFU}$ ). The Front Range, which forms the eastern edge of the Colorado Rockies, has heat flow of 84 to $105 \mathrm{~mW} / \mathrm{m}^{2}(2.0$ to $\geq 2.5 \mathrm{HFU})$. Reduced heat flow $\left[50\right.$ to $67 \mathrm{~mW} / \mathrm{m}^{2}(1.2$ to $1.6 \mathrm{HFU})$ characterizes most of the southern Rockies, but in the Rio Grande rift it is $85 \mathrm{~mW} / \mathrm{m}^{2}$ (>2.0 HFU) (Reiter et al. 1979b; Sass et al. 1980).

Several basement controlled northeast-trending shear zones cut the Southern Rockies in northern Colorado and southeastern Wyoming. These show up as linear gravity trends and aeromagnetic anomalies and have been mapped from surface geology. The best known is the Colorado Mineral Belt (CMB), which is a zone of late Cretaceous and early Tertiary age mineralization and igneous intrusion. The Nash Fork shear zone in southeastern Wyoming is parallel to the $C M B$ and is also the location of Tertiary intrusive activity. The Nash Fork shear zone defines a major geologic and geophysical boundary. It separates Precambrian basement of two different ages, 2.5 billion years to the north of the zone and 1.7 billion years to the south (Brinkworth and kleinkopf 1972). Gravity decreases markedly across the zone and heat flow increases from 46 to $63 \mathrm{~mW} / \mathrm{m}^{2}$ (1.1 to $\left.1.5 \mathrm{HFU}\right)$ on the northwest to $>67 \mathrm{~mW} / \mathrm{m}^{2}(>1.6 \mathrm{HFU})$ on the southeast (E. D. Decker, Los Alamos National Laboratory, personal communication, 1980). Crustal thickness increases to the south, to $50 \mathrm{~km}$ in the center of the Colorado Rockies $(40 \mathrm{~km}$ to the north and south) (Smith 1978). The Rockies south of the Nash Fork shear are characterized by negative Bouguer gravity anomalies associated with shallow granitic intrusions (Brinkworth and Kleinkopf 1972) and Airy-Heiskmen, isostatic gravity lows (Woollard 1966). There is also a prominent gravity low over the San Juan Volcanic Field (Brinkworth and Kleinkopf 1972).

With above normal to very high thermal gradients (locally $>65^{\circ} \mathrm{C} / \mathrm{km}$ ) and extensive low-temperature thermal systems over broad areas, almost the entire Rocky Mountain province in Colorado (in contrast with Wyoming) has geothermal potential (Kron and Heiken 1980; Muffler 1979). The approximately 200 thermal springs in Colorado are mostly associated with the Middle-to-Upper Cenozoic volcanic fields and areas of young tectonic activity bordering the Rio Grande ift, the San Juan volcanic field and the Colorado Mineral Belt. The four 
KGRA's in the Colorado Rocky mountains are in the Rio Grande rift: Mineral Hot Springs $\left[105^{\circ} \mathrm{C}\right.$ estimated reservoir temperature (ERT)], Valley View, Poncha, and Alamosa (Muffler 1979).

Three factors of particular interest to HDR are present in the colorado Rockies: regionally high heat flow not confined to isolated hydrothermal systems, exposed and covered Laramide plutons, and extensive Precambrian exposures in the Front Range and Laramie Mountains and buried Precambrian basement surface above sea level beneath most of the the province (Fig. 27, Mallory et al. 1972).

5. Colorado Plateau. The Colorado plateau in Colorado is characterized by below normal heat flow $\left[\leq 63 \mathrm{~mW} / \mathrm{m}^{2}(\leq 1.5 \mathrm{HFU})\right]$. The eastern perimeter however has heat flow of $92 \mathrm{~mW} / \mathrm{m}^{2}$, locally $105 \mathrm{~mW} / \mathrm{m}^{2}$ (>2.2 HFU, locally >2.5 HFU) [reduced 42 to $63 \mathrm{~mW} / \mathrm{m}^{2}(1.0$ to $1.5 \mathrm{HFU})$ ] and gradients $>50^{\circ} \mathrm{C} / \mathrm{km}$ (Reiter et al. 1979a). The higher values are related to active normal faulting and minor late Tertiary-Quaternary volcanism. The area is also characterized by relatively low seismicity, and local gravity lows (Mallory et al. 1972). There is minor Precambrian exposure in the area (Mallory et al. 1972), and the 01 ympic-Wichita Lineament, a major crustal feature, trends southeast through the region (Baars 1976) separating the Colorado plateau from the Colorado Rockies. In the northeastern Uinta Basin, there is apparently a geopressurized area, with above normal heat flow (Muffler 1979).

6. Great Plains. Although low-to-average values $\left[42\right.$ to $64 \mathrm{~mW} / \mathrm{m}^{2}$ (1 to 1. $5 \mathrm{HFU}$ )] are the rule (Sass et al. 1980), moderate-to-high heat flow [75 to $105 \mathrm{~mW} / \mathrm{m}^{2}$ (1.8 to $\left.\left.2.5 \mathrm{HFU}\right)\right]$ and gradients of $>45^{\circ} \mathrm{C} / \mathrm{km}$ are reported locally, e. g. , east-central Wyoming; western Denver Basin; Raton Basin (Muffler 1979; Sass et al. 1980). The Powder River Basin reportedly has heat flow of 71 to $88 \mathrm{~mW} / \mathrm{m}^{2}$ (1.7 to $2.1 \mathrm{HFU}$ ) (Blackwell 1969; E. D. Decker, Los Alamos National Laboratory, personal communication, 1980). Silica values outline an area of $\geq 84 \mathrm{~mW} / \mathrm{m}^{2}(\geq 2.0 \mathrm{HFU})$ in the Denver Basin and Las Animas Arch of Colorado and southeast Wyoming (Sass et al. 1980). Petroleum well temperature data also show this area to have low-temperature geothermal potential (Whipple 1979). In Colorado and northern New Mexico, there is a transition, from above normal values $\left[\geq 105 \mathrm{~mW} / \mathrm{m}^{2} \quad(\geq 2.5 \mathrm{HFU})\right]$ near the eastern borders of the southern Rockies and Rio Grande rift, to normal values $\left[\leq 63 \mathrm{~mW} / \mathrm{m}^{2}(1.5 \mathrm{HFU})\right]$ farther eastward into the Great Plains (Sass et al. 1980). 


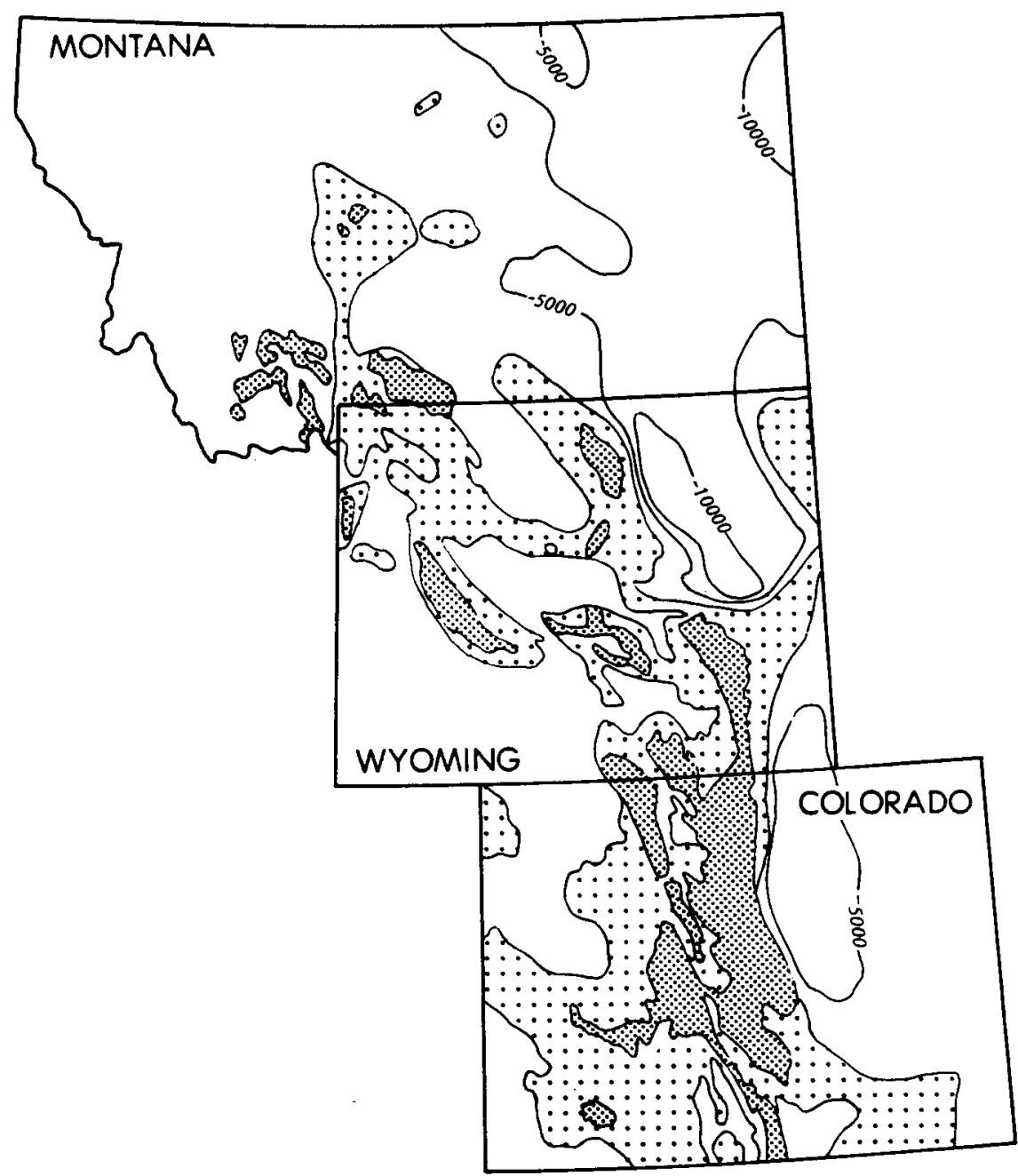

$\begin{gathered}\text { Contours on Precambrian surface, shown in Great Plains province only } \\ \text { (contour interval } 5000 \mathrm{ft} \text { ). }\end{gathered}$
$\therefore:$ Pexposed Precambrian surface
$\therefore:$ Precambrian rocks, buried but above sea level

Fig. 27.

Precambrian igneous and metamorphic rock surfaces.

The only noteworthy hydrothermal area in the Great Plains is in the Judith Mountains/Little Rockies (Montana) area, a low-temperature hydrothermal area (Muffler 1979). The Black Hills (Precambrian metamorphic and intrusive ocks) are characterized by moderate-to-high heat flow $\left[79\right.$ to $88 \mathrm{~mW} / \mathrm{m}^{2}(1.9$ to 
2. $1 \mathrm{HFU}$ ), with a reduced flux of $\backsim 59 \mathrm{~mW} / \mathrm{m}^{2}$ ( $\left.\left.\sim 1.4 \mathrm{HFU}\right)\right]$ comparable to Basin and Range values (Sass et al. 1980).

The Great Plains province may have HDR geothermal reservoirs buried beneath deep sedimentary basins. Crystalline basement is generally 4700 to $5000 \mathrm{~m}$ deep in the Williston and Powder River Basins, but may be shallower (<2200 m) in central Montana and eastern Colorado (Denver Basin) (D. Foley, University of Utah, personal communication, 1980; Bechtel National, Inc. 1980). The Madison and Dakota formations are large volume thermal aquifers underlying much of the Great Plains and may account for most of the elevated temperatures reported in petroleum wells throughout the Great Plains (Whipple 1979).

The Great Plains province is essentially aseismic (except along the western border) and has only limited young faulting, although there are some major (older) northeast- and west-northwest-trending fault zones. Magnetic anomalies relfect variations in the Precambrian basement rocks (Mabey 1978).

D. Best Prospects for HDR Geothermal Resources

The best prospects in the Rocky Mountain States of Colorado, Wyoming, and Montana are in the Rio Grande rift, the Colorado Mineral Belt, and the San Juan volcanic field in the Colorado Rockies; the Yellowstone-Absaroka-Jackson area in the Middle or Wyoming Rockies; and the Marysville-Helena-Butte area (Boulder batholith/Elkhom Mountains volcanics complex) in the Montana Rockies (Fig. 27). More geophysical surveys and heat-flow measurements are needed throughout most of this region to better define, or discover, HDR geothermal areas. 


\section{MIDCONTINENT REGION: EVALUATION OF HDR RESOURCES (Carol LaDelfe)}

In general, the basement geology of the U.S. midcontinent region (i.e., from the Rocky Mountains to the Appalachians) is consistent with the classic model of an accreting continent. Archean rocks of Minnesota are flanked by Precambrian rocks of increasingly younger age (Van Schmuss and Bickford, in press). Recent investigations of this "stable continental interior" have led to some conclusions that affect the search for geothermal energy sites in this region. Deep burial of the basement rocks by Phanerozoic sediments has hindered examination of and discouraged understanding of geologic and structural details of the midcontinent basement. As geophysical techniques are increasingly applied in the search for energy sources and for identification of seismic hazards, a view of this region is emerging that helps to explain the occasional earthquakes that occur from Arkansas to Ohio (Zoback et al. 1980) and to indicate areas of upward displacement of the Curie point isotherm in the Mississippi Embayment (von Frese et al. 1980). These areas may be suitable for development of geothermal energy reservoirs. To date, however, no contour map of Curie point isotherm depth or depth to other isothermal surfaces has been produced for the Midcontinent region. Such a map would greatly expedite a rough estimate of the regional HDR resource.

In fact, evaluation of the HOR geothermal resource base in the midcontinent region of the U.S. is still in the early stages. The Midcontinent Hot Dry Rock Group (MHDRG), consisting of researchers from Purdue University and investigators at the University of Pittsburgh, University of Texas at Dallas, University of Texas at El Paso, and New Mexico State University, began a project in March 1980 to develop a strategy for assessing the HDR geothermal potential of the midcontinent region. Researchers from the University of Nebraska-Omaha and from the Kansas Geological Survey are doing work in Nebraska and Kansas, respectively. This report summarizes the work of the MHDRG and other investigators to date.

\section{A. Precambrian Basement-Rock Investigations in Northeastern Kansas}

Basement rock units of Kansas, as in much of the rest of the midcontinent, are obscured by a few thousand feet of Paleozoic and younger sedimentary rocks. When the Kansas Geological Survey and the Kansas District of the Water 
Resources Division of the USGS proposed drilling four holes to study the hydrologic properties of the Arbuckle formation, the Los Alamos HDR program agreed to provide funding necessary to deepen the holes into the Precambrian basement.

Two holes were located on circular, positive, 1000-gamma, magnetic anomalies in eastern Kansas. Thermal logging was conducted by personnel from Southern Methodist University (SMU) and cuttings were sent to D. Blackwell of SMU for thermal conductivity measurements and heat-flow calculations. Precambrian cores of plutonic rocks were recovered from these holes and studied by geophysical, petrologic, and geochronological methods. Both samples are granite, composed mainly of microcline, plagioclase, quartz, biotite, and minor muscovite.

The ages of the plutons are $1361 \pm 6 \mathrm{Myr}$ and $1339 \pm 12 \mathrm{Myr}$, significantly younger than other samples collected from the Kansas and Missouri basement. Rock from the Miami County hole in northeast Kansas was found to have approximately $2 \%$ magnetite and an unusually high rate of heat generation (11 HGU as compared to 5 or 6 for normal granite). Preliminary geothermal gradient data indicate $28^{\circ} \mathrm{C} / \mathrm{km}$ to $36^{\circ} \mathrm{C} / \mathrm{km}$ in eastern Kansas; heat flow is being calculated (Steeples and Bickford 1980).

B. Midcontinent Hot Dry Rock Project

The MHDRG is evaluating the entire midcontinent region from the Rockies to the Appalachians and from the U.S.-Canadian border to the Gulf Coastal Plain (Fig. 28). Principal investigator is William $J$. Hinze at Purdue University. His consortium of at least 10 earth scientists, who have a broad range of expertise, have three primary goals. The first is to develop a strategy for midcontinent HDR assessment, and the second is to assemble existing data and collect new data where there are gaps. The third goal is to test the above strategy at three sites where existing data indicate possible geothermal anomalies: western Nebraska, the Upper Mississippi Embayment, and southeastern Michigan. Two of these sites were determined using the heat-flow map of the U.S. (Swanberg and Morgan 1978), which was derived by the empirical relationship between silica geothermometry and heat flow (Fig. 29).

1. Western Nebraska Test Site. The western Nebraska test site lies within a $83.6 \mathrm{mWm} /{ }^{2} \quad(2.0 \mathrm{HFU})$ closed contour on the Swanberg-Morgan map and is an area where bottom-hole temperature gradients average $36^{\circ} \mathrm{C} / \mathrm{km}$ or more 



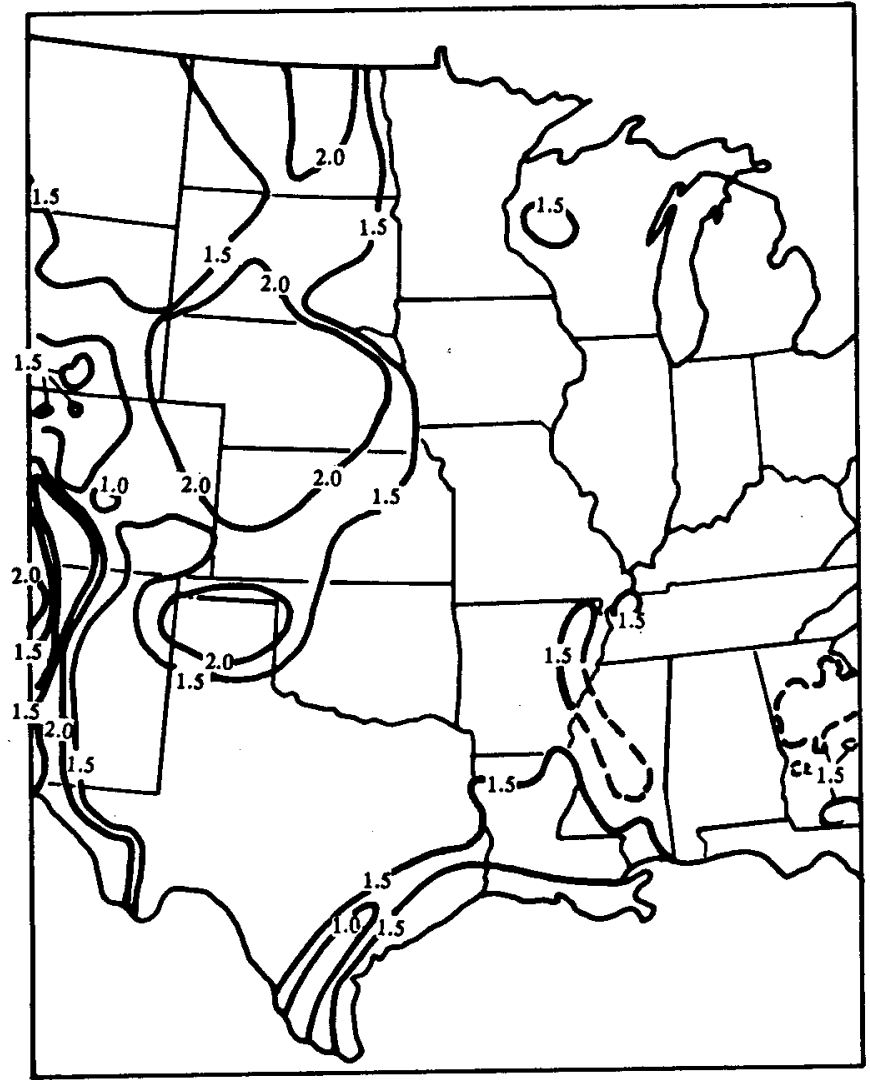

Contour intervals $=0.5 \mathrm{HFU}$

Fig. 29. Heat flow based on silica geothermometry. Contours in heat flow units. (Swanberg and Morgan (1978).

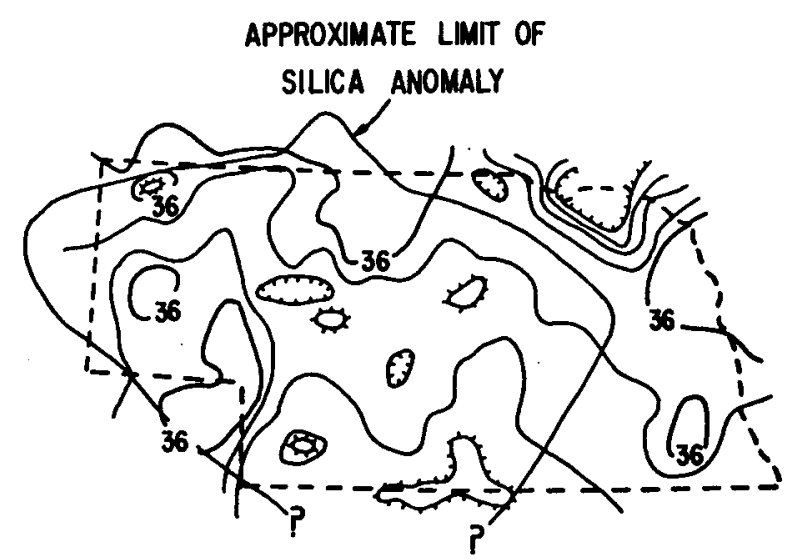

O SCALE km 300

Fig. 30. Bottom-hole temperature gradients for Nebraska (after AAPG-USGS 1976). Contours are at $3.7^{\circ} \mathrm{C} / \mathrm{km}$ $\left(0.2^{\circ} \mathrm{F} / 100 \mathrm{ft}\right)$ intervals. The $36^{\circ} \mathrm{C} / \mathrm{km}$ contour corresponds to the $2.0^{\circ} \mathrm{F} / 100 \mathrm{ft}$ contour on the AAPB-USGS map. Limit of silica anomaly taken from Swanberg and Morgan (1978).

Gosnold (1980), who has collected geothermal gradient and heat-flow data confirming the existence of the anomaly, is continuing his investigation in cooperation with members of the MHDRG.

2. Upper Mississippi Embayment Test Site. The New Madrid seismic zone is presently the most seismically active area in the central and eastern U.S. (Zoback et a1. 1980). The area of interest to the MHDRG is known as the Upper Mississippi Embayment Test Site and is located in the southern portion of that seismic zone. Seismic activity is centered in a postulated rift zone that was first active during Precambrian time and has been reactivated periodically through geologic time (Zoback et a1. 1980). Late Paleozoic to Late Cretaceous plutons and smaller intrusions occur along the seismic zone from northern Arkansas to western Kentucky. A Cenozoic intrusion is said to exist under the 
Ridgely area south of New Madrid as detected by seismic reflection. Interpretation of gravity and magnetic data from the area suggests an upward-deflected Curie point isotherm within the rift zone (von Frese et al. 1980).

The Upper Mississippi Embayment contains areas where heat flow is greater than $62.7 \mathrm{~mW} / \mathrm{m}^{2}$ (1.5 HFU) on the Swanberg and Morgan map (Fig. 29). Silica geotemperatures averaged over $1^{\circ}$ by $1^{\circ}$ areas, are as high as $81^{\circ} \mathrm{C}$ in northern Arkansas; heat flow as computed from bottom-hole temperatures is possibly as high as $130.8 \mathrm{~mW} / \mathrm{m}^{2}(3.13 \mathrm{HFU})$ within the Upper Mississippi Embayment (Fig. 32).

3. Southeastern Michigan Test Site. The southeastern Michigan test site was chosen because gravity and magnetic anomalies indicate the possible presence of a granitic pluton that may produce anomalous radiogenic heat. Insulating

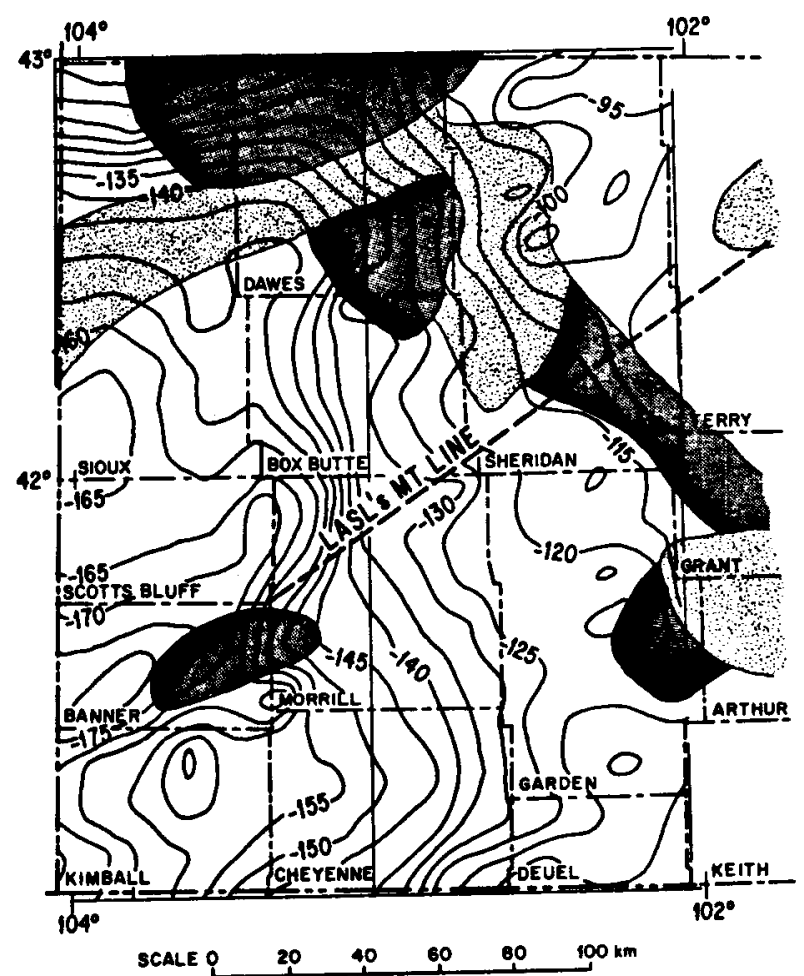

Fig. 31. Preliminary Bouguer gravity anomaly map and basement geology from Lidiak (1972), for the western Nebraska test site area. Light shaded areas correspond to granitic basement rocks and dark shaded regions to schists and granofels. The Laboratory's proposed MT line also is shown.

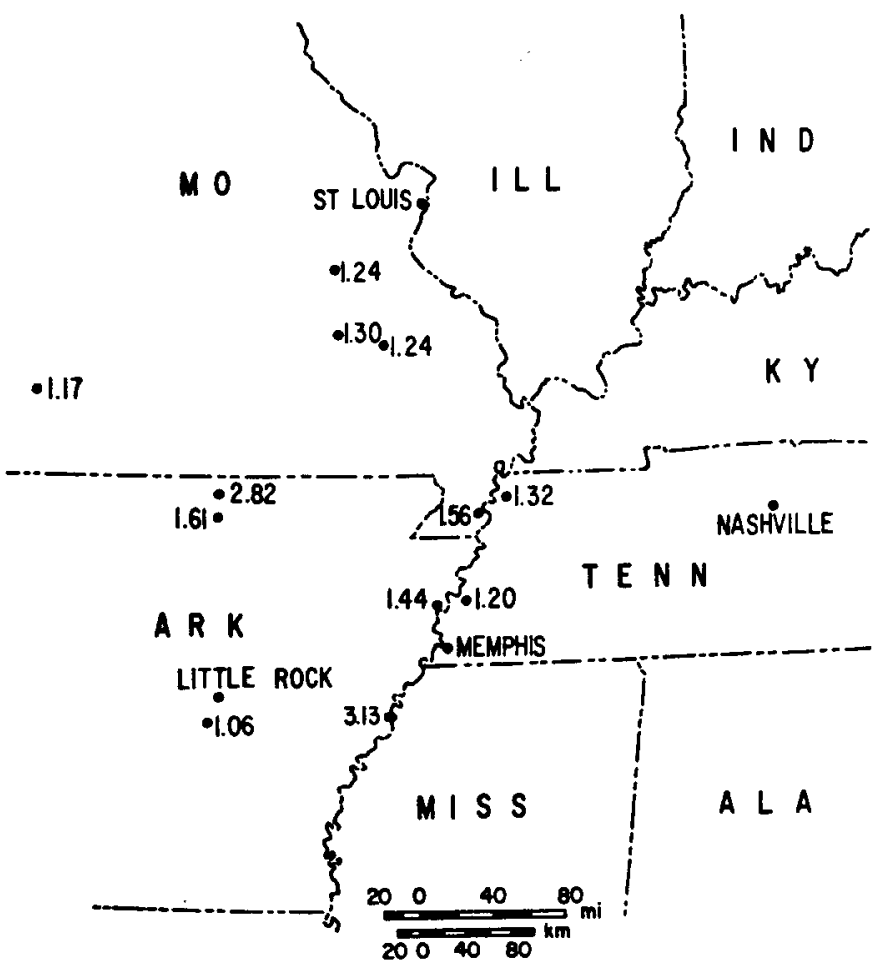

Fig. 32. Heat flow data for Upper Mississippi Embayment test site ( $\mathrm{HFU}=10^{-6} \mathrm{ca} 1 / \mathrm{cm}^{2} \mathrm{~s}=$ $41.9 \mathrm{~mW} / \mathrm{m}^{2}$ ). 
shale units overlying this area may, therefore, be concealing and preserving an anomalous supply of thermal energy. The negative gravity anomaly is evident when the regional gravity field is removed (subtracted) from the data (Fig. 33). From this, the pluton model of Fig. 34 was constructed. Similar treatment of observed magnetic data results in a residual magnetic anomaly roughly corresponding to the gravity anomaly (Fig. 35).
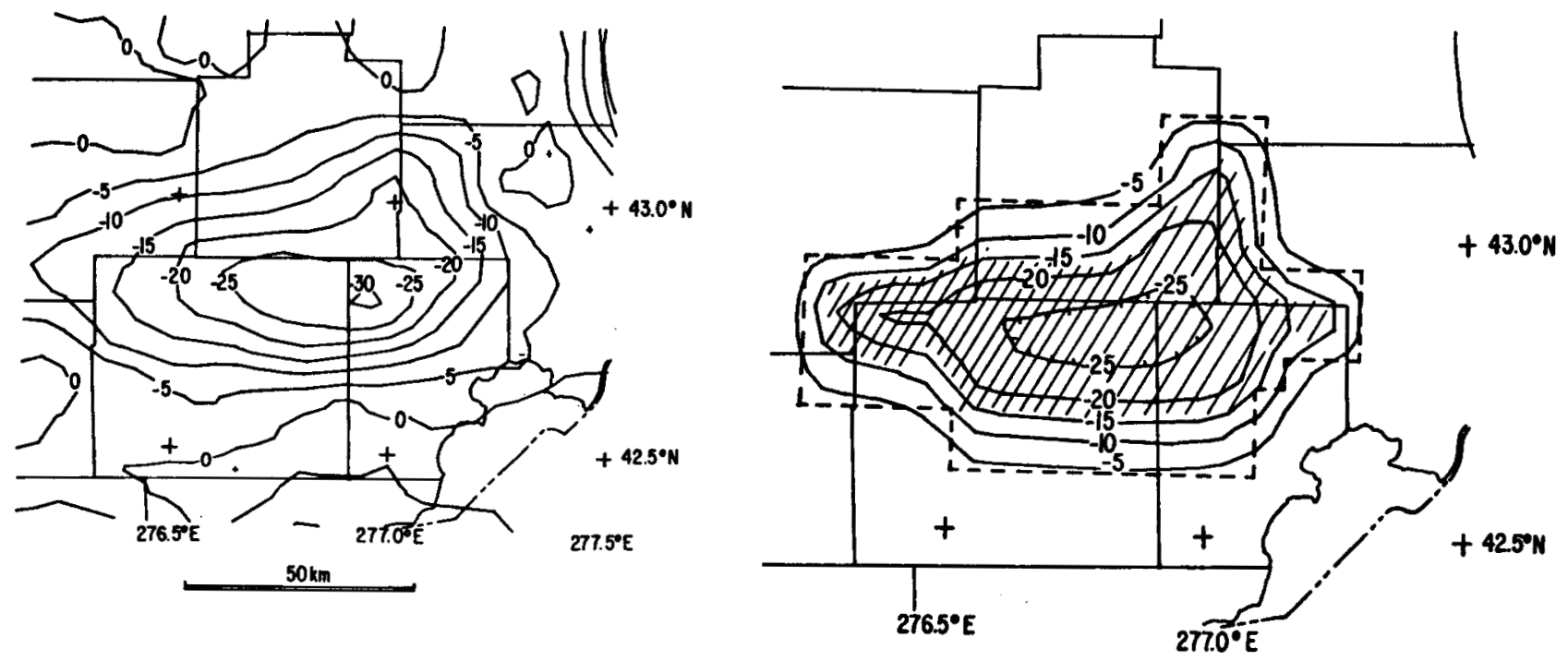

Fig. 33. Residual gravity anomaly at MHDRG study area of SE Michagan (units $=m$ gal).

Fig. 34. Pluton model showing model gravity anomaly in SE Michigan (units - $\mathrm{m}$ gal).

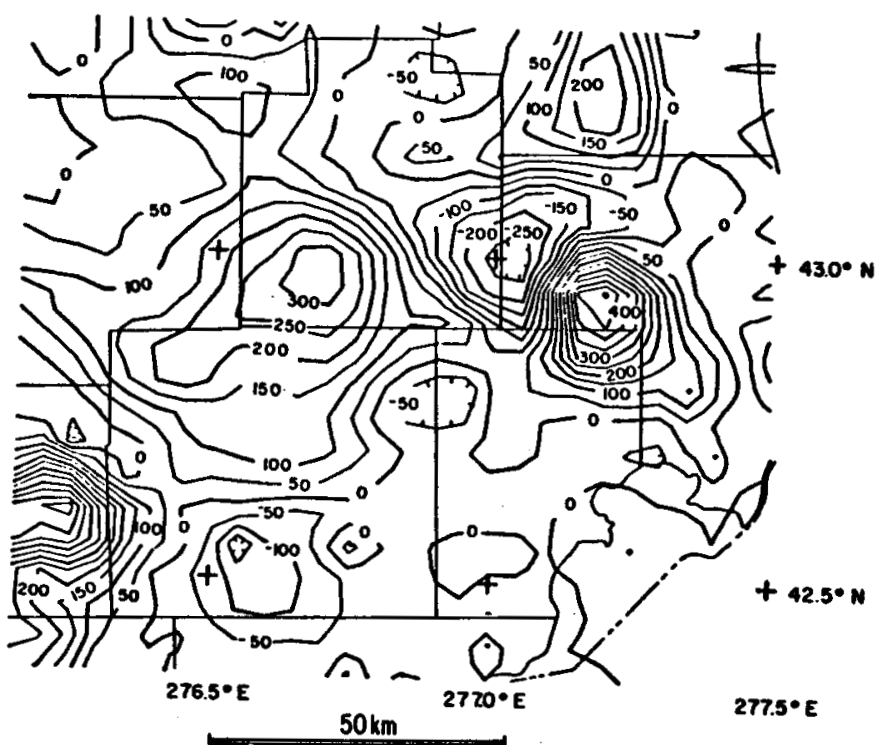

Fig. 35. Residual magnetic anomaly roughly corresponds to gravity anomaly. 
These, then, are the areas where the proposed exploration strategy is being tested and where efforts will be concentrated in completing data sets and producing an assessment of HDR resource potential.

4. Illinois Deep Drill Hole. In early 1980 the opportunity arose for scientific use of a deep drill hole near Winslow in northern Illinois. The MHDRG has several studies underway on data from the drill hole and core. Core samples are being studied to determine their petrologic and physical properties and thermal conductivity; they are also being subjected to gamma-ray spectrometry. The thermal gradient at about 2-km depth in Precambrian basement is about $24^{\circ} \mathrm{C} / \mathrm{km}$ (Commonweal th Edison, unpublished data, 1980). Fourteen hundred gravity stations were established adjacent to the hole, and data are being reduced and combined with existing gravity data to facilitate modeling the pluton encountered by drilling. A regional magnetic survey around the area is planned.

\section{CONCLUSION}

The HDR geothermal evaluation of the midcontinent is in its earliest stage with study begun over most of the region. Nevertheless, great amounts of data have been compiled and significant new data have been collected. As time progresses, the MHDRG and other researchers will add tremendously to our understanding of the energy potential of basement rock in the midcontinent and of the general geologic and tectonic evolution of this part of our country. 


\section{EASTERN REGION: HDR RESOURCE ASSESSMENT (J. C. Maxwel1)}

HDR resource assessment in the eastern United States involves investigations in three physiographic provinces: the Atlantic Coastal Plain, the Appalachian Highlands, and the Interior Plateaus. Work in the Coastal Plains is limited to areas underlain by young, semiconsolidated sediments that dip gently toward the sea. The Appalachian Highlands, as used here, arbitrarily include New England, the Appalachian Piedmont, the folded Appalachian Mountains, and the Adirondack Mountains. The Allegheny, Appalachia, and Cumberland Plateaus comprise the Interior Plateaus. There is little visible evidence of present geothermal energy in these regions. Volcanic activity ended 200 Myr and only a few warm springs discharge in the east, most of which issue near Saratoga Springs, New York, and in the east-central Appalachian Mountains. Consequently, assessment of geothermal energy in the eastern states has relied upon geophysical measurement of temperature, gravity, magnetic, and electric fields. Measurement of temperature gradients and calculation of heat flow has been the primary method of finding areas of above-average geothermal potential.

\section{A. Atlantic Coastal Plain}

The geology of the Atlantic Coastal Plain consists of unconsolidated to semiconsolidated sediments that dip seaward (less than $2 \mathrm{~m} / \mathrm{km}$ to locally more than $20 \mathrm{~m} / \mathrm{km})$. The sediments lie on a gently seaward-sloping surface of crystalline metamorphic and igneous rocks. Little is known about these underlying basement rocks because they have been reached by only a few widely spaced drill holes. The limited number of drill holes plus existing geophysical data indicate that the Coastal Plain basement is similar to the crystalline rocks of the adjacent Piedmont province. In the Piedmont, $300 \mathrm{Myr}$ granitic plutons containing heat-producing radioactive minerals have intruded into the older metamorphic rock (Costain et al. 1979; 1980). These plutons cause characteristic subcircular gravity anomalies. Above average geothermal gradients associated with similar gravity anomalies in the Coastal Plain are believed to be the result of similar granitic plutons buried by the sediments.

Geothermal gradients have been measured in shallow (300-m) holes drilled near the gravity lows (Figs. 36, 37, 38, Costain 1979; 1980) and in available $0 i l$ and gas wells (Smith 1979). Gradients as high as $37^{\circ}$ to $45^{\circ} \mathrm{C} / \mathrm{km}$ have been 


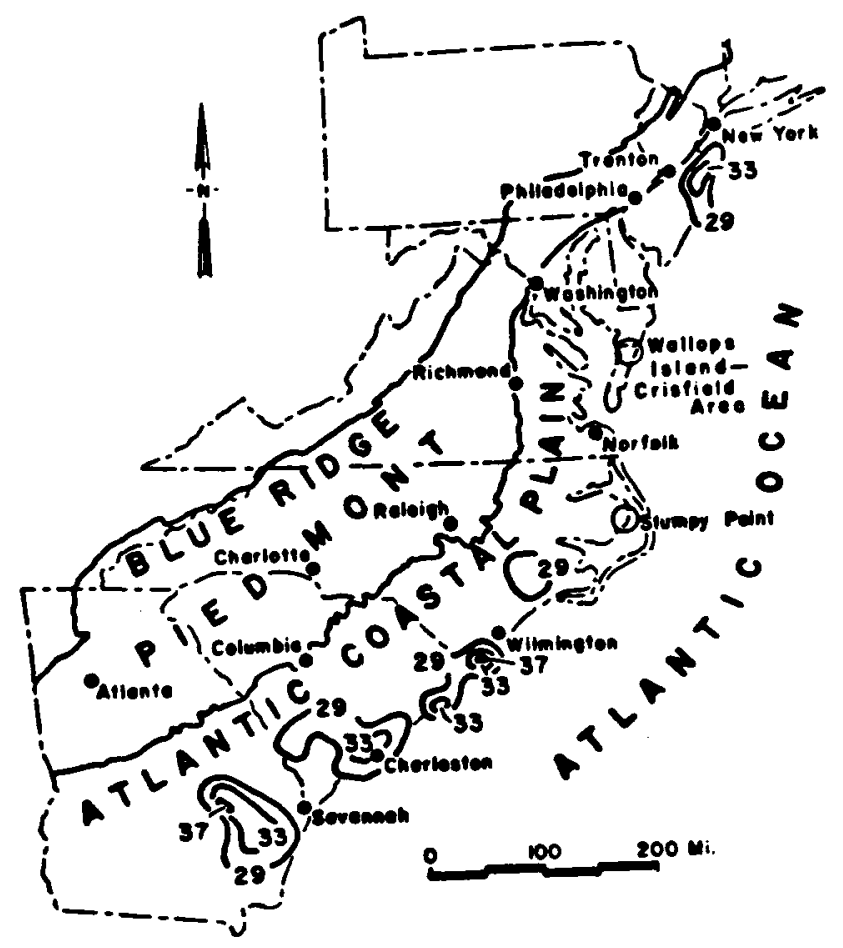

Fig. 36. Abnormally high geothermal gradients in the eastern United States. Contours are in ${ }^{\circ} \mathrm{C} / \mathrm{km}$ (from Costain 1980).

found. Thermal conductivities measured on samples from these wells have permitted calculations of heat flow. Values reported by the Virginia Polytechnic Institute and State University group range from a maximum of $79 \mathrm{~mW} / \mathrm{m}^{2}(1.9 \mathrm{HFU})$ at Stumpy Point, North Carolina, $77 \mathrm{~mW} / \mathrm{m}^{2}$ (1.8 HFU) at Wallops Island, Virginia, and $75 \mathrm{~mW} / \mathrm{m}^{2}(1.8 \mathrm{HFU})$ at Withams, Virginia, to average values near $40 \mathrm{~mW} / \mathrm{m}^{2}$ (1.0 HFU). At the present time, the best prospects for HDR resources in the Coastal Plain seem to be the buried granitic plutons.

Because of locally high gradients and heat flow, the area between Wallops Island, Virginia, and Crisfield, Maryland, has been selected for detailed evaluation. The Crisfield well, $1.7 \mathrm{~km}$ deep, has a bottom-hole temperature of $58^{\circ} \mathrm{C}$ in Paleozoic metarhyolite (Fig. 39). Gamma-ray logs of overlying sediments are presented in Fig. 40 .

B. Appalachian Highlands

Attention has been focused on the Conway granite of the White Mountain intrusive series in New Hampshire since the early 1960s, when it was assessed 

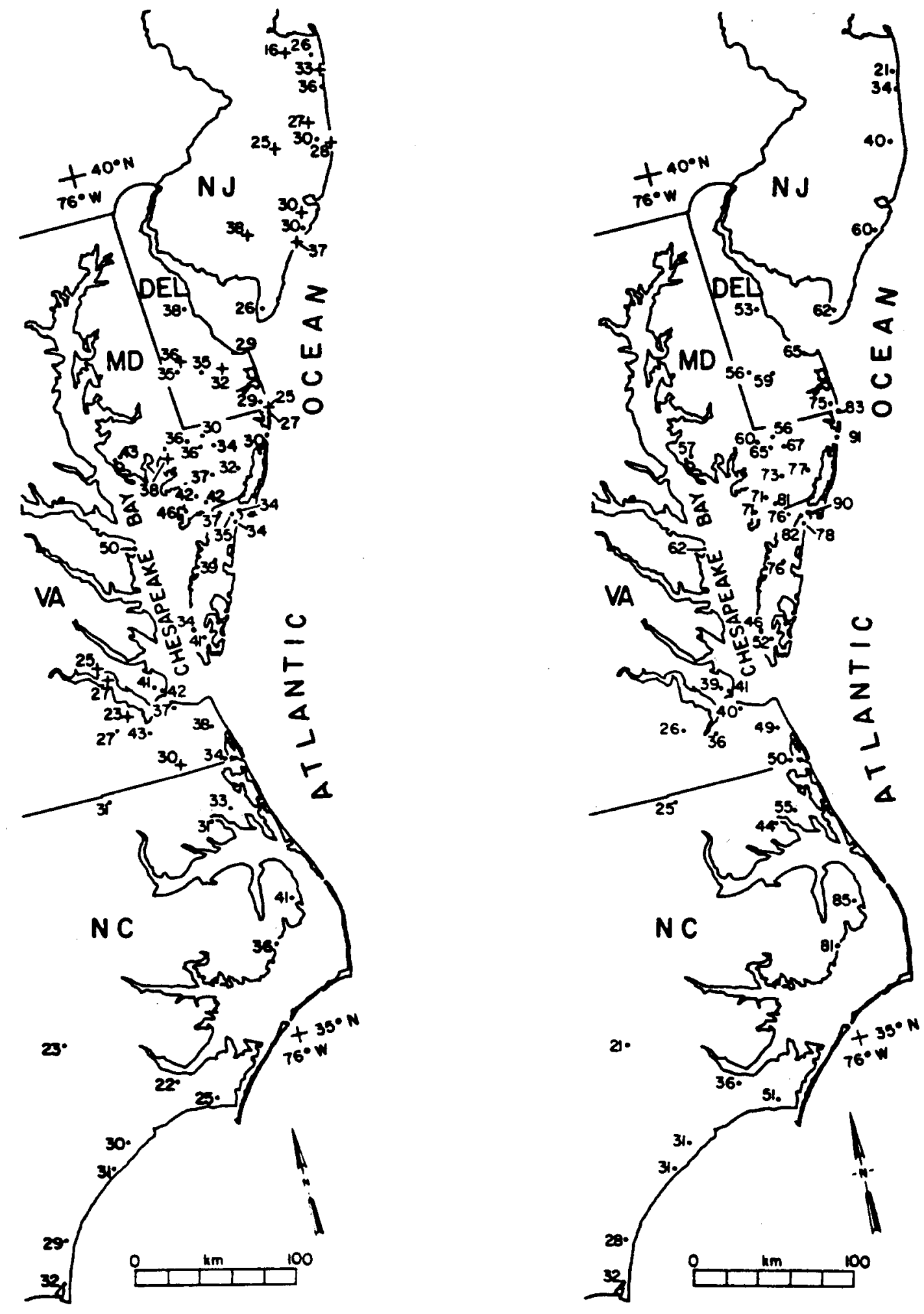

Fig. 37. Geothermal gradients in ${ }^{\circ} \mathrm{C} / \mathrm{km}$,

Fig. 38. Estimated basement surface temperature in ${ }^{\circ} \mathrm{C}$, from Costain 1979. 


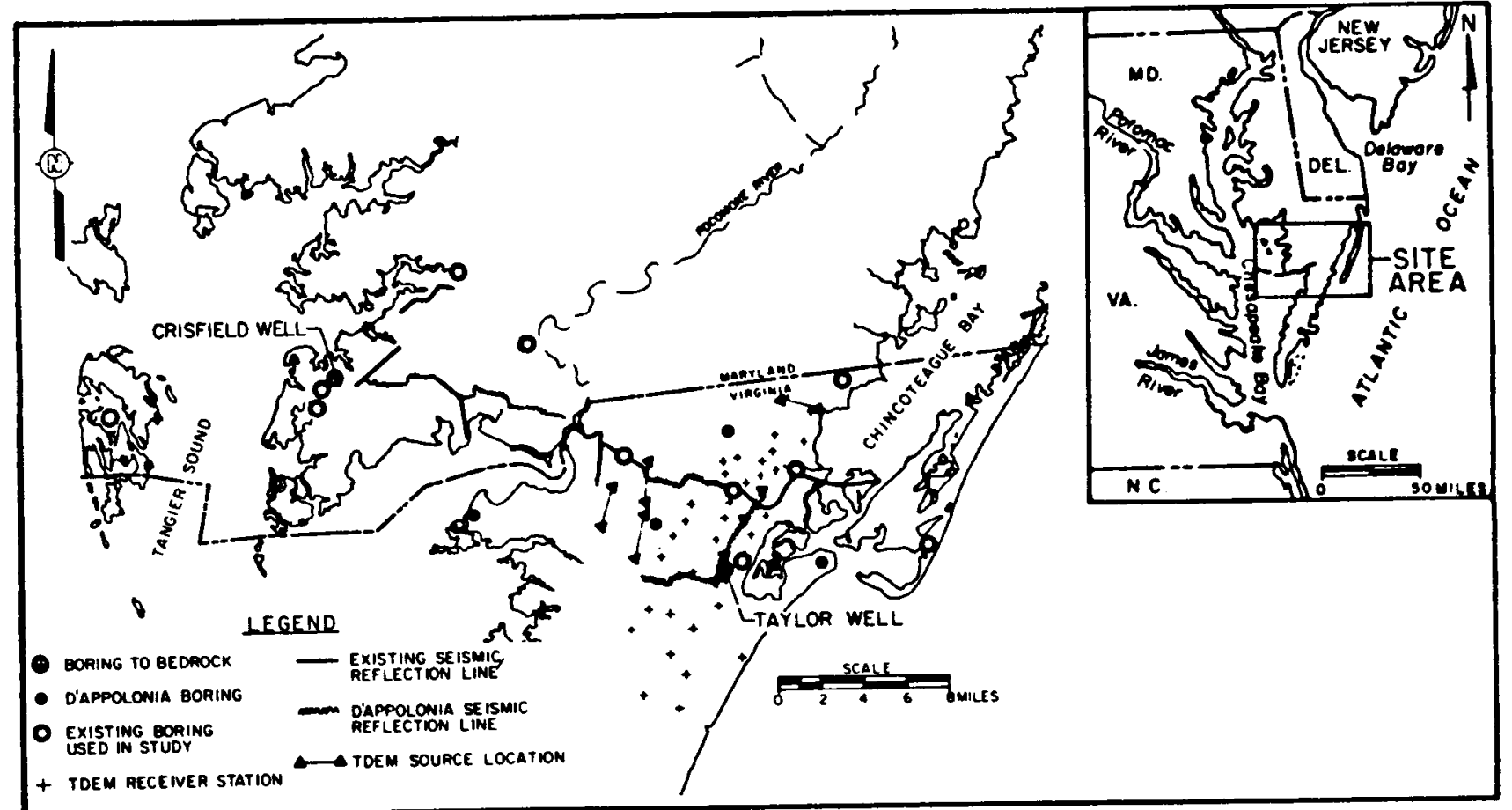

Fig. 39. Site location (from Schubert 1980).

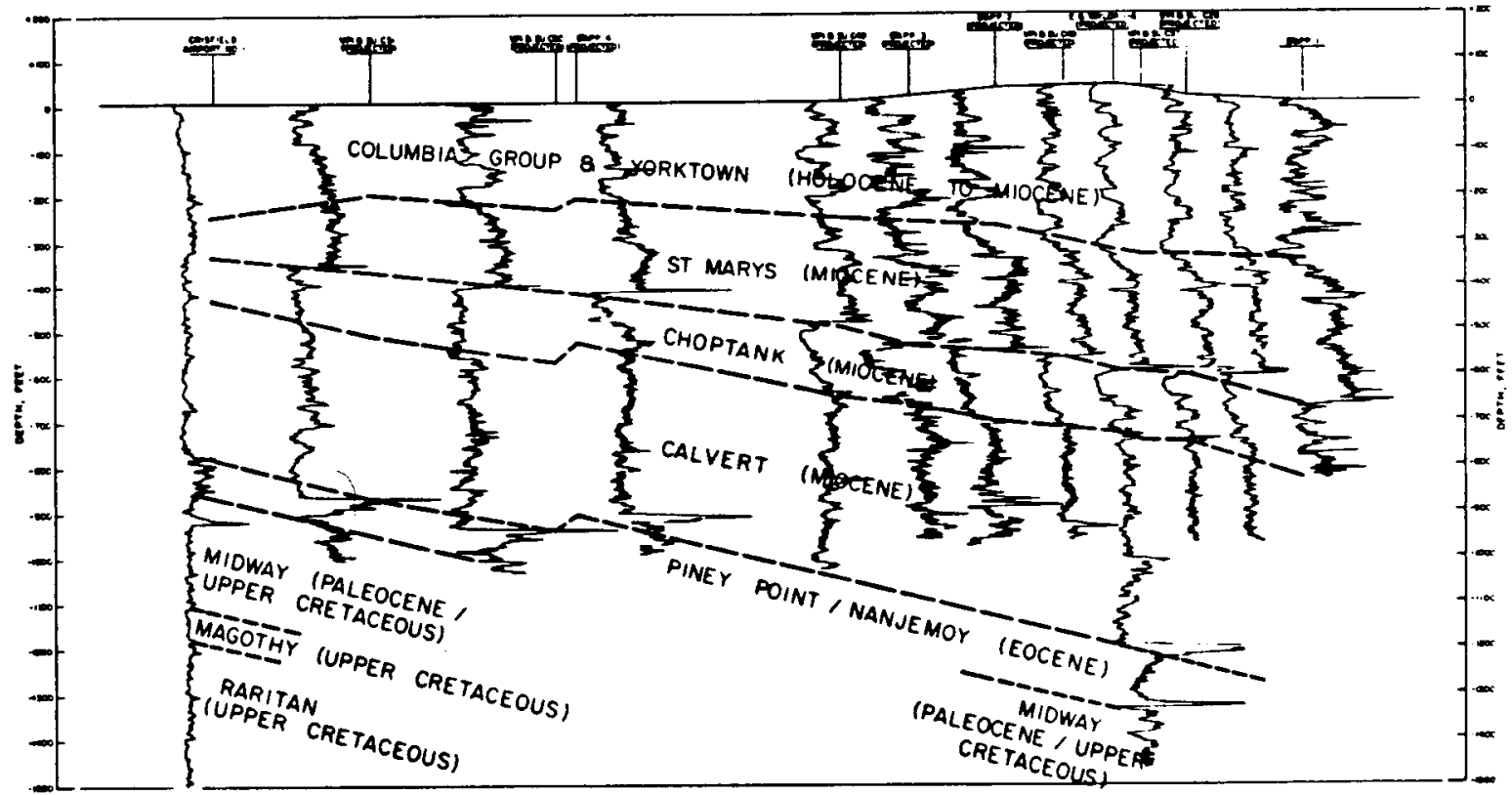

Fig. 40. Gamma- $\log$ stratigraphic correlation across the HDR site (from Schubert 1980). 
as a possible source of thorium. These plutons have higher concentrations of radioactive elements than any other known pluton in the U.S. Thermal gradients measured in this granite range from 27 to $29.9^{\circ} \mathrm{C} / \mathrm{km}$ in $300-\mathrm{m} \mathrm{drill}$ holes. Heat flow, after correcting for topographic and geologic effects, ranges from 82 to $92 \mathrm{~mW} / \mathrm{m}^{2}(2.0-2.2 \mathrm{HFU})$, the highest values found to date in the eastern U.S. A detailed gravity survey by Wetterauer and Bothner (0sberg et al. 1978) has shown the plutons near North Conway to be approximately $5 \mathrm{~km}$ deep, with a projected temperature of $170^{\circ} \mathrm{C}$ at $6-\mathrm{km}$ depth. Measurements of gradients in available wells and demonstration flame-jet drilling of one or two gradient holes were planned for early 1981. Measurement of gradients in available wells throughout southern New Hampshire, Vermont, and Massachusetts is in progress (G. Simmons, Massachusetts Institute of Technology, unpublished data).

Most of the exploration in the central Appalachians has been accomplished by the Virginia Polytechnic Institute and State University. Shallow drilling and surface sampling of six granitic plutons in the Piedmont has shown a linear relationship between heat flow $q$ and heat generation $A$ of $q=0.69+$ $6.9 \times 105 \mathrm{~A}$, with $\mathrm{A}$ ranging from 0.25 to $1.1 \mathrm{p} \mathrm{cal} / \mathrm{cm} 3 / \mathrm{s}(11$ to $17 \mathrm{HGU})$. A study of the warm springs in the folded Appalachians has shown that they are the result of deep circulation of meteoric water along major fault zones transverse to the folds. A gabbro drilled near Baltimore, Maryland, has relatively high thermal conductivity, so the thermal gradient and bottom-hole temperatures at depth are lower than expected. A survey of bottom-hole temperatures of oil and gas wells in the folded Appalachians has begun in West Virginia. Gradients found thus far range from 18 to $25^{\circ} \mathrm{C} / \mathrm{km}$ (D. Hodge, State University of New York, Buffalo, New York, unpublished data, 1980).

C. Interior Plateaus

The Interior Plateaus extend westward from the folded Appalachian Ridge and Valley section and from the northern boundary of New York southward to Alabama. They are underlain by a sequence of nearly horizontal Paleozoic, well indurated shales, sandstones, and some 1 imestones from $2 \mathrm{~km}$ to more than $5 \mathrm{~km}$ thick. Under this blanket of sedimentary rock is a folded, metamorphosed basement of crystalline rocks reached by only a few widely scattered drill holes. Little is known about rock units under the sedimentary cover; they are assumed to be generally similar to those of the Piedmont. 
Most of the work in this region has consisted of compiling bottom-hole temperatures from existing wells and measuring gradients in new wells to determine areas of above-normal thermal gradients. Heat flow has been calculated for several widely spaced wells for which the conductivity of cores or cuttings has been determined. Average and maximum gradients and heat flow are given in Table VI.

\section{TABLE VI}

AVERAGE AND MAXIMUM GRADIENTS AND HEAT FLOW OF INTERIOR PLATEAUS

\begin{tabular}{|c|c|c|c|c|c|c|}
\hline \multirow[b]{3}{*}{ New York } & \multirow{2}{*}{\multicolumn{3}{|c|}{$\frac{\text { Thermal Gradients }}{\text { Average }}$}} & \multicolumn{3}{|c|}{ Heat Flow } \\
\hline & & & & Average & Maxil & \\
\hline & 23.06 & 41.2 & ${ }^{\circ} \mathrm{C} / \mathrm{km}$ & 59.3 & 81.0 & $\mathrm{~mW} / \mathrm{m}^{2}$ \\
\hline Pennsylvania & 20.04 & 38.9 & $"$ & 57.9 & 61.2 & $"$ \\
\hline Ohio & 20.66 & 37.5 & $"$ & 56.7 & 56.7 & $"$ \\
\hline West Virginia & N.A. & N.A. & $"$ & 53.8 & 58.7 & $"$ \\
\hline
\end{tabular}

In New York, a group headed by Dennis Hodge at State University of New York, Buffalo, and assisted by Chandler Swanberg and Paul Morgan of New Mexico State University, has compiled relevant geologic and geophysical data. Two anomalous areas, the Cayuga anomaly, $50 \mathrm{~km}$ southwest of Syracuse, and the East Aurora anomaly, southeast of Buffalo, have temperature gradients exceeding $36^{\circ} \mathrm{C} / \mathrm{km}$. Silica geothermometry of ground waters from these areas indicates a maximum temperature of $56^{\circ} \mathrm{C}$ at the Cayuga anomaly and $60^{\circ} \mathrm{C}$ at the East Aurora anomaly. Both anomalies are associated with gravity lows, which may be caused by granitic plutons in the underlying basement. Enhanced radioactivity in the plutons could contribute to the geothermal anomalies. Bottom-hole temperatures available from several thousand oil wells are being re-evaluated to improve the state's thermal gradient map. Temperature logging of selected wells in the anomalous areas is in progress. 
By working from the literature and compiling data, a group in Ohio, headed by Yoram Eckstein from Kent State University, has located at least 15 wells suitable for heat flow measurements. They have completed measurements of thermal conductivity on 44 core samples from four of these wells. The Los Alamos National Laboratory has analyzed samples from these wells and from other well cores to determine their uranium, thorium, and potassium-40 content in order to calculate heat generation and heat flow. No well-defined anomalies have yet been identified; al though gradients in southeastern ohio are generally higher than el sewhere in the state.

\section{CONCLUSIONS}

It is apparent that sources of low-to-moderate temperature geothermal energy occur widely throughout the eastern United States. Exploration for and evaluation of these sources have not yet progressed as far as have those for shallow higher temperature sources in the West. As the technology to utilize low-temperature sources becomes available, eastern geothermal resources will make an increasing contribution to America's energy base. 
VIII. OTHER STUDIES SUPPORTING OVERALL PROJECT

Various studies relate to the resource evaluation program as a whole rather than to a single region. Among them are magnetotelluric (MT) surveys in New Mexico and Arizona, the purpose of which is to develop geophysical techniques specific to HDR exploration; the construction of a conductive geothermal gradient map of the conterminous U.S. based on gradients that appear to have reached thermal equilibrium; and several studies of a variety of igneous systems designed to yield information about how the HDR and hydrothermal portions are distributed throughout the systems. Section VIII summarizes these studies.

\section{A. Magnetotelluric Surveys to Support HDR Mapping (Mark E. Ander)}

The resource evaluation and exploration program conducted by the Los Alamos National Laboratory for the HDR geothermal program is supporting regional MT surveys of New Mexico and Arizona. This effort is intended to investigate geophysical techniques specific to HDR exploration. The surveys consist of over 200 MT sites along several long profiles with site spacings of 15 to $20 \mathrm{~km}$ ( $\mathrm{Fig} .41$ ). The MT lines are located in areas where the results of other geophysical and geological studies indicate the greatest potential for HDR geothermal resources while also traversing tectonic province boundaries (Aiken and Ander 1980). The MT study is aimed at mapping the depth to the pervasive deep electrical conductor within the crust and/or upper mantle, thus producing a regional description of electrical conductors within the crust and/or upper mantle of the Colorado Plateau, adjacent Basin and Range Province, and the Rio Grande rift.

The electrical conductivity structure of the earth's crust and upper mantle can be divided roughly into three regions: a surface layer of low resistivity (usually less than $75 \Omega \mathrm{m}$ ) associated with sediments and ground water; a high resistivity layer (usually over $500 \Omega \mathrm{m}$ ) associated with low porosity crystalline basement containing very little water; and a deep conductive layer. The depth to this conductive layer may vary from deep in the mantle to the upper crust and is usually assumed to be an indicator of high temperature and/or partial melting. Pollack and Chapman (1977a, b) have calculated that $60 \%$ of the surface heat flow is produced in the crust. Lateral increases in heat production in the crust give rise to elevated temperatures 


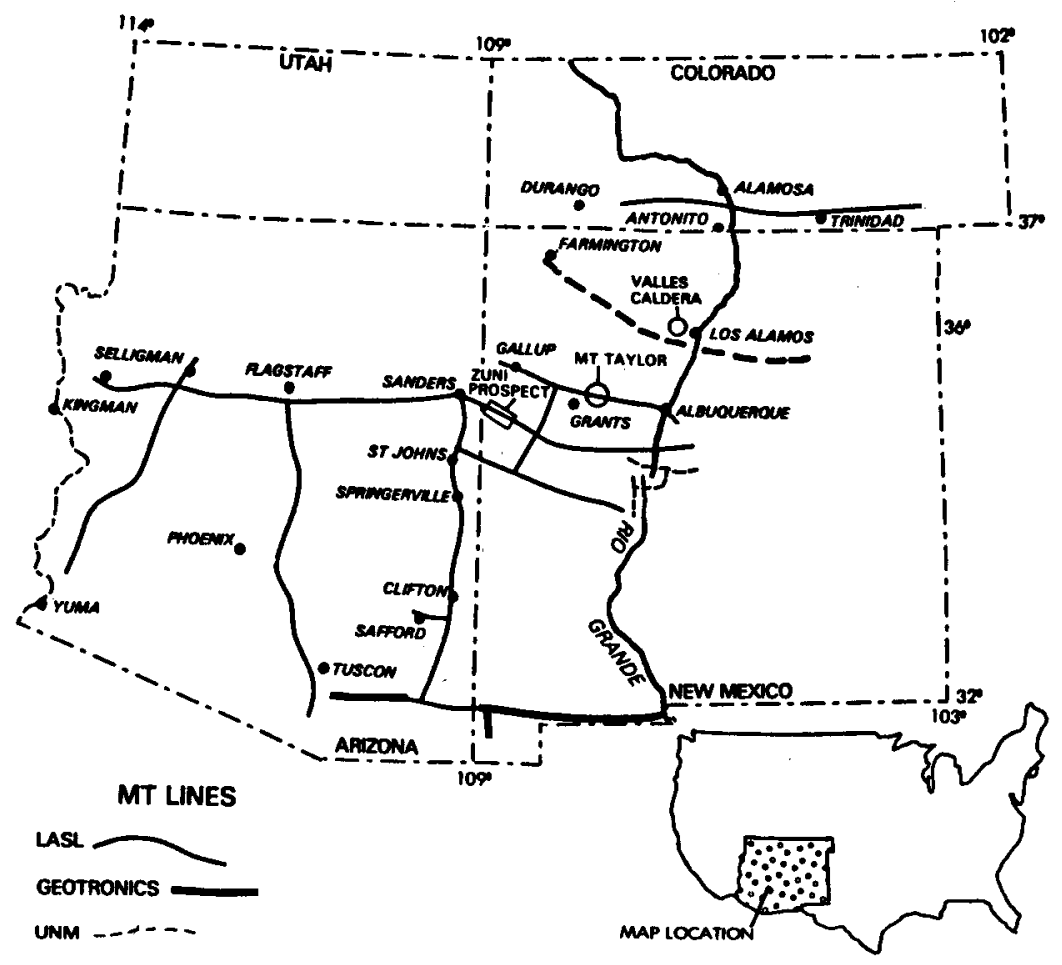

Fig. 41. Location of MT soundina profiles in New Mexico and Arizona.

and surface heat flow. Consequently, lateral variations at depth of the deep conductive zone should correlate with surface heat flow regardless of whether the conductor is within the crust or in the upper mantle. Thus, a shallow depth to the conductive zone may indicate a surface area of higher geothermal potential. From data collected around the world, A'dam (1978) compared the variation of heat flow with the depth to crustal conductors. He has suggested an empirical exponential relation between depth to the crustal conductor and surface heat flow.

Porath (1971) has given an al ternative explanation for the presence of some crustal conductive zones that is unrelated to composition or temperature at depth. Large electrical current systems established in major surface conductors may bias nearby MT soundings. These electrical currents are channeled in the conductor in regions of major lateral conductivity contrast such as along the seacoast, in large sedimentary basins, and in deep continental 
rift valleys. MT soundings located near one of these major current systems may have their apparent resistivity sounding curves biased to indicate an anomalously conductive zone at depth and possibly give rise to the interpretation of a deep crustal feature. These lateral effects are particularly enhanced if the MT sounding is located over a highly resistive surface. Care must be taken to anticipate the location of such current systems.

1. Description of MT Lines. The MT study in western Arizona is concentrated on the Castle Dome and Aquarius HDR prospects and the Colorado Plateau/Basin and Range boundary. The Castle Dome prospect, located in Yuma County, coincides with a large amplitude gravity low (Aiken and Ander 1980) and with a maximum temperature gradient of $70^{\circ} \mathrm{C} / \mathrm{km}$ measured in the center of the area (Shearer 1979). A mid-Tertiary caldera may underly the gravity low (Gutmann et a1. 1980; Gutmann 1981). The Aquarius area is characterized by high heat flow, shallow depth to the Curie isotherm, and a gravity low, and it appears to be associated with a shallow depth to the electrical conductive zone (West and Laughlin 1979; Aiken and Ander 1980). The region contains only Miocene basalt and minor intermediate and silicic volcanic rocks (Goff et al. 1979).

In central Arizona a profile runs through the Tucson, Phoenix, and Flagstaff areas and traverses the Basin and Range/Colorado Plateau boundary. The area around Tucson has heat flow of $100.3 \mathrm{~mW} / \mathrm{m}^{2}(2.4 \mathrm{HFU}$ ) (after Shearer 1979). Southeast of Phoenix, geothermal gradients greater than $36^{\circ} \mathrm{C} / \mathrm{km}$ have been measured (Swanberg et al. 1977).

In eastern Arizona the survey concentrates on the thermally anomalous Safford-Clifton, Springerville, and Sanders areas as well as on the Colorado Plateau/Basin and Range boundary and the Jemez lineament (Mayo 1958). In west-central New Mexico the survey concentrates on the Zuni HDR prospect, the Jemez lineament, and the Rio Grande rift, all marked by high heat flow. Seismic data has led to the possible discovery of deep-seated magma bodies near Socorro, New Mexico (Sanford 1977). In the Rio Grande rift, the Los Alamos survey merges with a detailed MT study of the rift conducted by Jiracek et al. (1979) of the University of New Mexico.

A telluric-magnetotelluric survey in the Jemez Mountains of northern New Mexico provided some data on the electrical properties of the geothermal system of the Valles Caldera (Hermance 1979). Hermance (supported by the USGS) has also completed a regional northwest-southeast MT survey across the rift. 
Nonproprietary MT data collected along lines from south of Tucson, Arizona, to El Paso, Texas, are also being studied; these data are available from Geotronics, Inc. (1979).

2. Zuni Uplift Area. Regions under investigation include the Jemez volcanic lineament and the Rio Grande rift in New Mexico. The first HDR demonstration site is located near the intersection of these two crustal structures in the Jemez Mountains. The Rio Grande rift, a major continental rift, is a Cenozoic feature consisting of narrow, en echelon tectonic basins. The rift's tectonic history and structure have been influenced by a series of northeast-trending shear zones, Precambrian in age, giving rise to structural lineaments. The Jemez lineament is one of these shear zones. Although the lineaments substantially predate the rift, they appear to be currently acting as a system of transform faults in conjunction with the rift spreading center (Chapin et al. 1978).

Both the rift and the Jemez lineament have greater than normal heat flow (Edwards et a1. 1978). The rift exhibits heat flow consistently above 104 $\mathrm{mW} / \mathrm{m}^{2}$ (2.5 HFU) while the Jemez lineament has heat flow ranging from 63 $\mathrm{mW} / \mathrm{m}^{2}$ to $104 \mathrm{~mW} / \mathrm{m}^{2}(1.5$ to $2.5 \mathrm{HFU})$, with a few measurements above 104 $\mathrm{mW} / \mathrm{m}^{2}(2.5 \mathrm{HFU})$. One area of particularly high heat flow is the region to the west of Grants and to the south of Gallup, New Mexico. The highest value measured in this region, $125 \mathrm{~mW} / \mathrm{m}^{2}$ (3.0 HFU) is located south of the town of Zuni on the Zuni Indian Reservation.

Both a regional deep $M T$ sounding survey and a $161 \mathrm{~km}^{2}$ detailed MT/audiomagnetotelluric (AMT) survey were planned for this region (Fig. 42). The regional MT survey consists of 56 deep soundings with a range in period from 0.05 to $2000 \mathrm{~s}$. Its objectives were to investigate the geometry of the pervasive deep electrical conductor in this region and to place the results of the detailed site in a regional context. The main objectives of the detailed study were to perform a detailed electrical evaluation of a possible HDR prospect to determine if a deep-seated body of high-temperature basement rock is present and to evaluate the MT/AMT method for exploring HDR prospects. Data collection for the regional survey was contracted to Williston McNeal and Associates and Argonaut Enterprises, and data collection for the detailed survey was contracted to Woodward Clyde Consultants. Both Woodward Clyde Consultants and Argonaut Enterprises used the remote reference noise reduction technique developed by Gamble et al. (1979a, b). Data collection has just been 


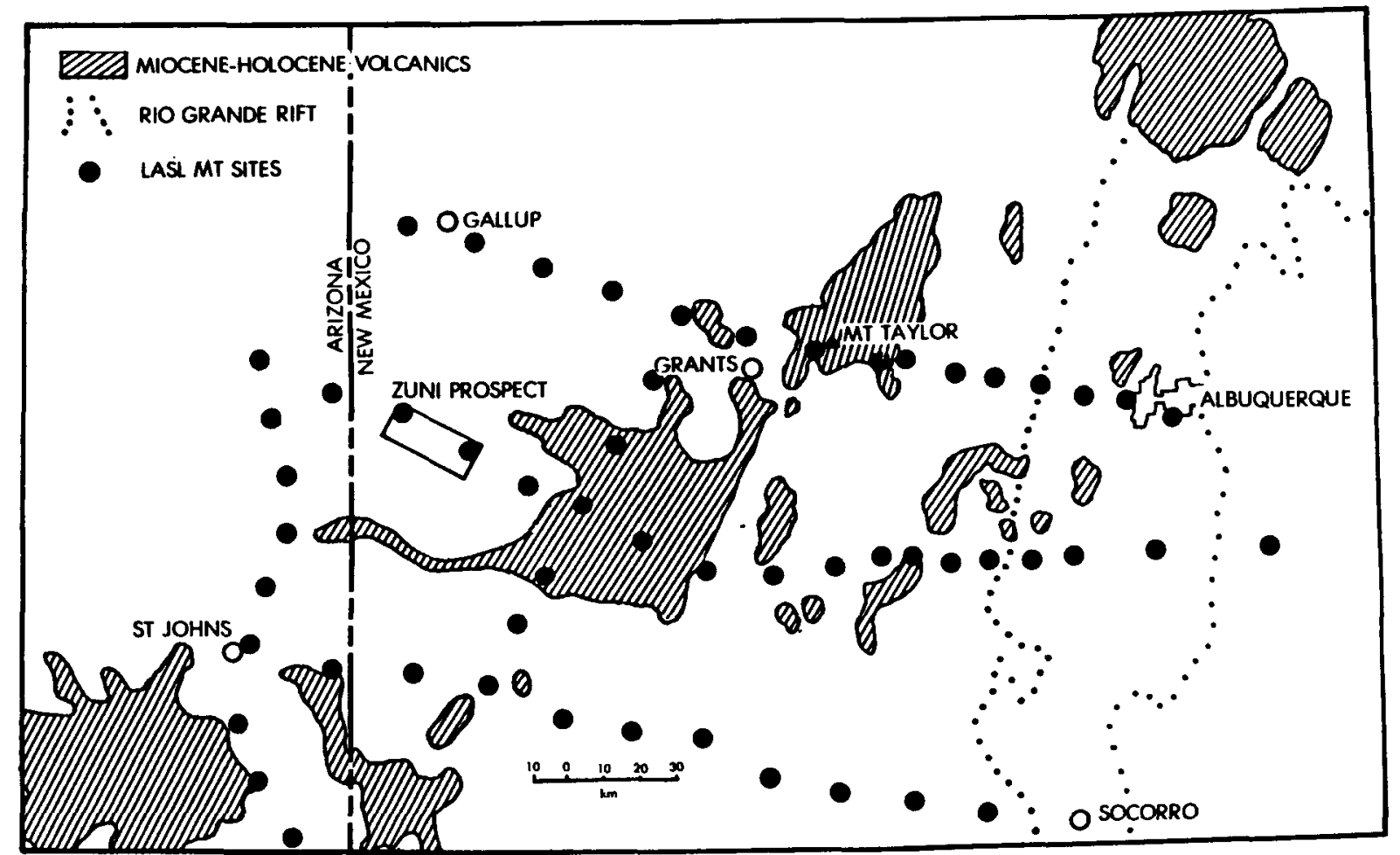

Fig. 42. Index map of western New Mexico showing Cenozoic volcanism, Rio Grande Rift, and locating Los Alamos National Laboratory magnetotelluric sites.

completed for the regional survey and one-dimensional analysis of much of it has been completed at this time. The detailed survey, located in the area of highest heat flow, has been completed.

Preliminary results of the regional study indicate that the Jemez lineament is associated with anomalously high electrical conductivity at shallow depths. Correlation of these preliminary results with teleseismic P-wave studies (Spence et al. 1979), heat flow (Edwards et al. 1978), and geology (Chapin et al. 1978) gives a consistent picture of a major lineament that extends deep into the lithosphere. The lineament acts as a conduit for magma and is the locus of thermal anomalies.

The detailed survey consisted of 119 scalar AMT stations and 25 tensor MT stations. AMT sites were spaced $1.6 \mathrm{~km}$ apart in a grid pattern. In scalar AMT, the ratio of the horizontal E-field component to the horizontal H-field component normal to it is computed. The electric field sensor is two 50-m cables grounded at either end, and the magnetic field sensor is a ferrite-cored coil with a response linear with frequency from less than $10 \mathrm{~Hz}$ to $40 \mathrm{KHz}$. 
Notch filters are used to reduce effects of "cultural noise" from $60 \mathrm{~Hz}$ power lines and higher harmonics. The apparent resistivities were determined from the $E$ to $H$ ratios measured at 10 different frequencies varying logarithmically from $12 \mathrm{~Hz}$ to $10.2 \mathrm{KHz}$. The purpose of the AMT was to search for any nearsurface electrical structures or lateral contacts. None were found, al though terrain effects near the mesa edges were observed. The detailed MT survey consisted of 6 soundings to $2000 \mathrm{~s}, 12$ soundings to $1000 \mathrm{~s}$, and 8 soundings to $500 \mathrm{~s}$ in period; the stations were spaced $3.2 \mathrm{~km}$ apart on a grid overlying the AMT grid. Stations 19 and 33 were chosen as reference sites and were occupied by each contractor. A deep well located in the northern portion of the study area was used to estimate depth to basement.

Figure 43 shows the apparent resistivity sounding curve taken at station 33 by Woodward Clyde consultants. It is representative of all 25 of the MT sounding curves. The MT curves show the same trend as the AMT results from 0.01 to $0.1 \mathrm{~s}$ period. Above about $1.0 \mathrm{~s}$ all the curves show a distinct rise in the apparent resistivity by 50-100 $\mathrm{sm}$ followed by a decrease in apparent resistivity at the long period end of the spectrum. The quality and consistency of the data and results were exceptionally good. Using real-time data processing in the field to analyze data quality while on the site, we were able to substantially reduce the random errors especially in the mid-band from 1 to $10 \mathrm{~s}$ where the MT signal strength is notoriously low. Their estimates were obtained by averaging over a sufficiently large data base to acquire desired data quality. This is a distinct advantage of real-time data processing. The curve fit is a least-squares polynomial that may vary from third to eighth order, depending on the lowest order which passes through at least $80 \%$ of the error bars. Note that some fine structure in the spectrum has been missed.

Figure 44 shows the apparent resistivity sounding curve taken at the same station by Argonaut Enterprises. Although this sounding is noisier than the previous sounding because of a smaller statistical base, the two soundings are almost identical. This sounding curve would typically be considered a good MT sounding. The mid-band from 1 to 10 seconds is generally noisy because of low signal strength. The long period data are generally noisy because of insufficient recording time. Note that much of the fine structure seen on the previous sounding also shows up in this sounding. This suggests that much of 


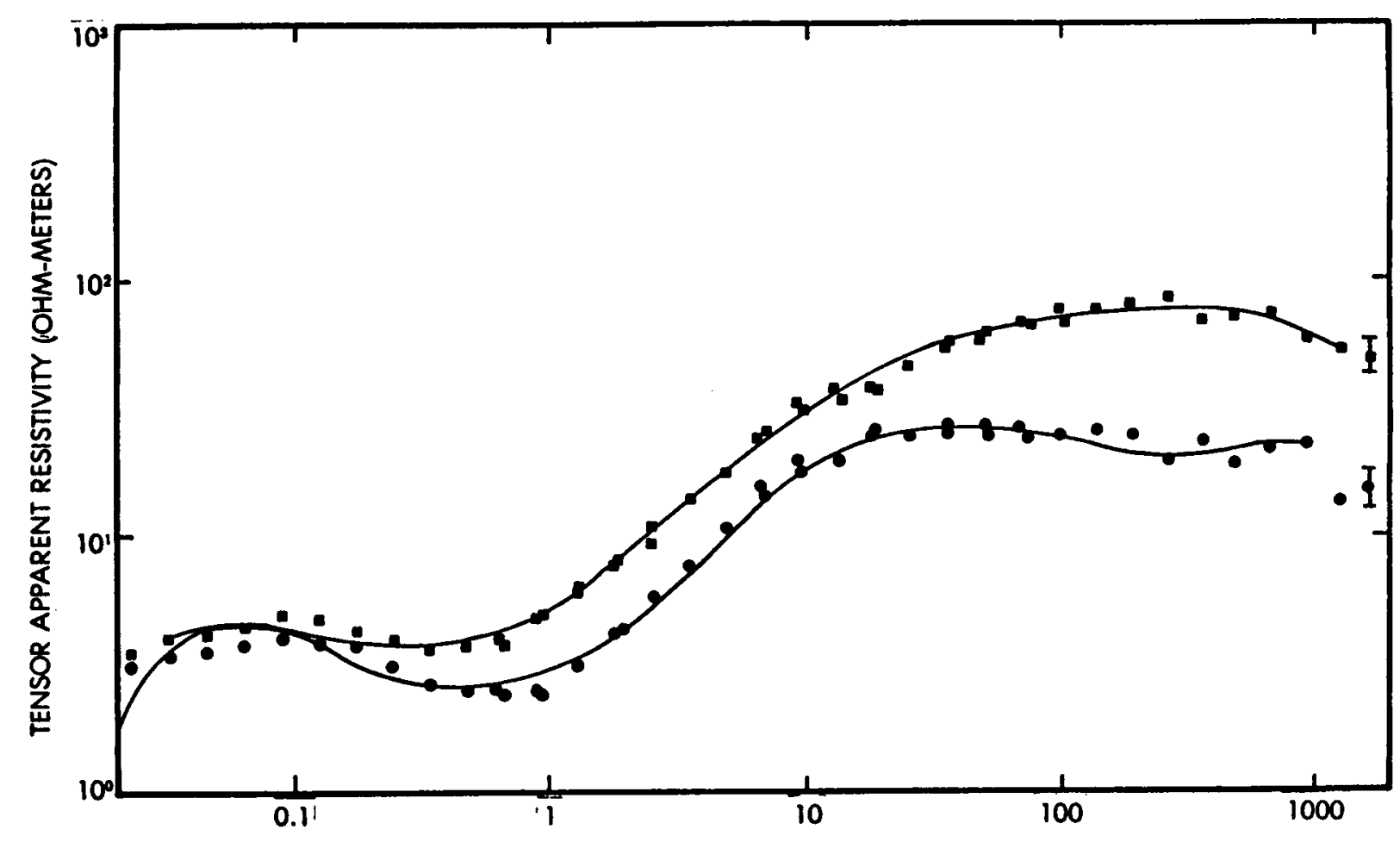

Fig. 43. MT sounding curve for station 33 taken by Woodward-Clyde Consultants (15 Sept 79).

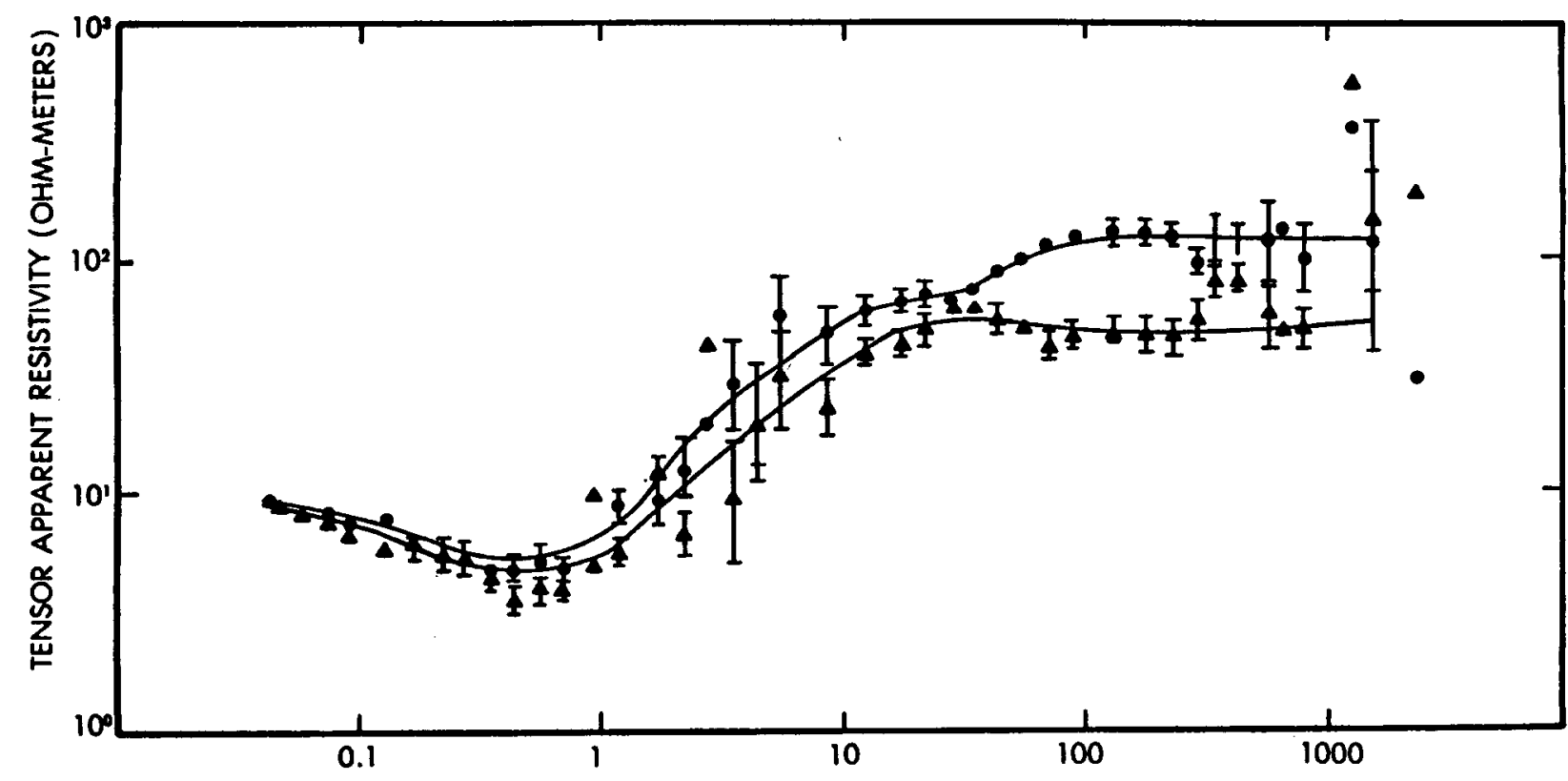

Fig. 44. MT sounding curve for station 33 taken by Argonaut Enterprises 50 confidence errors. 
the fine structure in good quality MT soundings may be real and not just due to statistical scatter.

There are numerous other earth response functions normally calculated in an MT survey. When taken together, these earth response functions confirm the presence of a relatively flat-lying, layered, two-dimensional electrical subsurface. One of the calculated earth response functions is the electrical strike direction. The strike direction is generally undefined at very short periods; but from about 1 to $100 \mathrm{~s}$, the strike aligns with the dominant surface structures with a mean of about $N 30^{\circ} \mathrm{W}$ along the gentle anticlines and synclines. This is also the direction of the deep canyon that cuts through the mesa terrain to the southeast. At longer periods, above $100 \mathrm{~s}$, the strike rotates about $90^{\circ}$ to a distinct and consistent $N 60^{\circ} \mathrm{E}$. This rotation is often abrupt and almost certainly represents a different trend within the metamorphic Precambrian basement. The Jemez lineament is located just to the southeast of the Zuni prospect and strikes approximately $N 55^{\circ} \mathrm{E}$. This strongly suggests a relationship between the deep structure beneath the Zuni prospect and the Jemez lineament. One-dimensional inversion was performed on each pair of sounding curves at each station using the algorithm developed by Petrick et al. (1977).

Eight stations were chosen along a line perpendicular to the deep electrical strike. These stations were used to produce a two-dimensional model in which the one-dimensional inversions were used as starting models. These sites were also chosen because their deep strike directions were closest to the estimated mean.

Three consecutive runs of the 2-D inverse modeling code developed by Jupp and Vozoff (1977) were made. Both the transverse electric and transverse magnetic components were used to model the apparent resistivity amplitude and phase. The modeling results are shown in Fig. 45 . The top $800 \mathrm{~m}$ is very conductive, overlying resistive basement. The depth to Precambrian basement in the reference well is $767 \mathrm{~m}$. From $800 \mathrm{~m}$ to $15 \mathrm{~km}$ the rocks are resistive. Below $15 \mathrm{~km}$ the rocks become much more conductive. The deep conductive zone grades from less conductive to the northwest to more conductive to the southeast in the direction of the Jemez lineament.

\section{B. Geothermal Gradient Map (Andrea Kron)}

In a preliminary attempt to identify the regional, conductive temperature regime across the U.S., a geothermal gradient map of the conterminous U.S. was 
compiled using gradients measured in wells that appear to have obtained thermal equilibrium (Kron and Heiken 1980). These data were gathered from published heat-flow literature and through heat flow/thermal gradient subcontracts administered by LoS Alamos. Measurements in a conductive regime are necessary for estimating depth to desired temperatures and are, therefore, important in determining the HDR resource base of the country. Approximately 900 wells are represented on the map (Kron and Heiken 1980; Fig. 46). The following criteria were used to determine the gradients:

- Wells must be deeper than $50 \mathrm{~m}$.

- Only the straight portion of the temperature-vs-depth curve was used to calculate a gradient using a least-squares approximation.

- Wells showing obvious hydrothermal interferences were not used. This eliminated most high-grade hydrothermal targets since these systems are dominated by convection.

- Only gradients from high-quality heat-flow measurements (for example, Reiter et al. 1975) were used.

- When gradients varied systematically down the hole because of changes in conductivity, a cumulative average of the least-squares gradient for each individual straight-line segment was used.

The regional picture that emerges is not unlike the heat-flow map of Sass et al. (1980; Fig. 47). Many of the variations displayed on our map are due to subjective contouring of the data. Contour lines were drawn on the basis of existing data rather than along physiographic boundaries. Comparison with the temperature gradient map of Guffanti and Nathenson (1980; Fig. 48), whose measurements represent wells deeper than $600 \mathrm{~m}$, shows regional similarities with exceptions in the Gulf Coastal Plain and north-central states. Lack of deep temperature measurements in the central states accounts for the differences in the two maps in this region.

Gradients of 30 to $45^{\circ} \mathrm{C} / \mathrm{km}$ dominate the tectonically active western U.S. and form a belt that trends through the Rio Grande rift in western New Mexico, northwest across western Colorado, the northern Basin and Range of Utah and Nevada, and the Snake River plain to the Cascades of Oregon and Washington. An anamalous extension of this trend into Nebraska may result from regional 


\begin{tabular}{|c|c|c|c|c|c|c|c|}
\hline NW & & & & & \llcorner & $\mathrm{cm}$ & SE \\
\hline STATION $=29$ & 27 & 25 & 59 & 57 & 91 & 87 & \\
\hline $200 \mathrm{~m}$ & $4.0 \Omega \mathrm{m}$ & & & & 25 & & \\
\hline & $6.0 \Omega m$ & & & & 4.0 & & \\
\hline $300 \Omega \mathrm{m}$ & 600 & 70 & & 800 & 1000 & 500 & 100 \\
\hline $10 \mathrm{~km}$ & 600 & & 700 & 800 & 1000 & 500 & 200 \\
\hline & $\Omega m$ & 30 & & 20 & 10 & 7 & 5 \\
\hline $70 s$ & & 30 & & & 30 & & $\mid 20$ \\
\hline
\end{tabular}

Fig. 45. Two-dimensional electrical resistivity model from detailed MT/AMT survey.

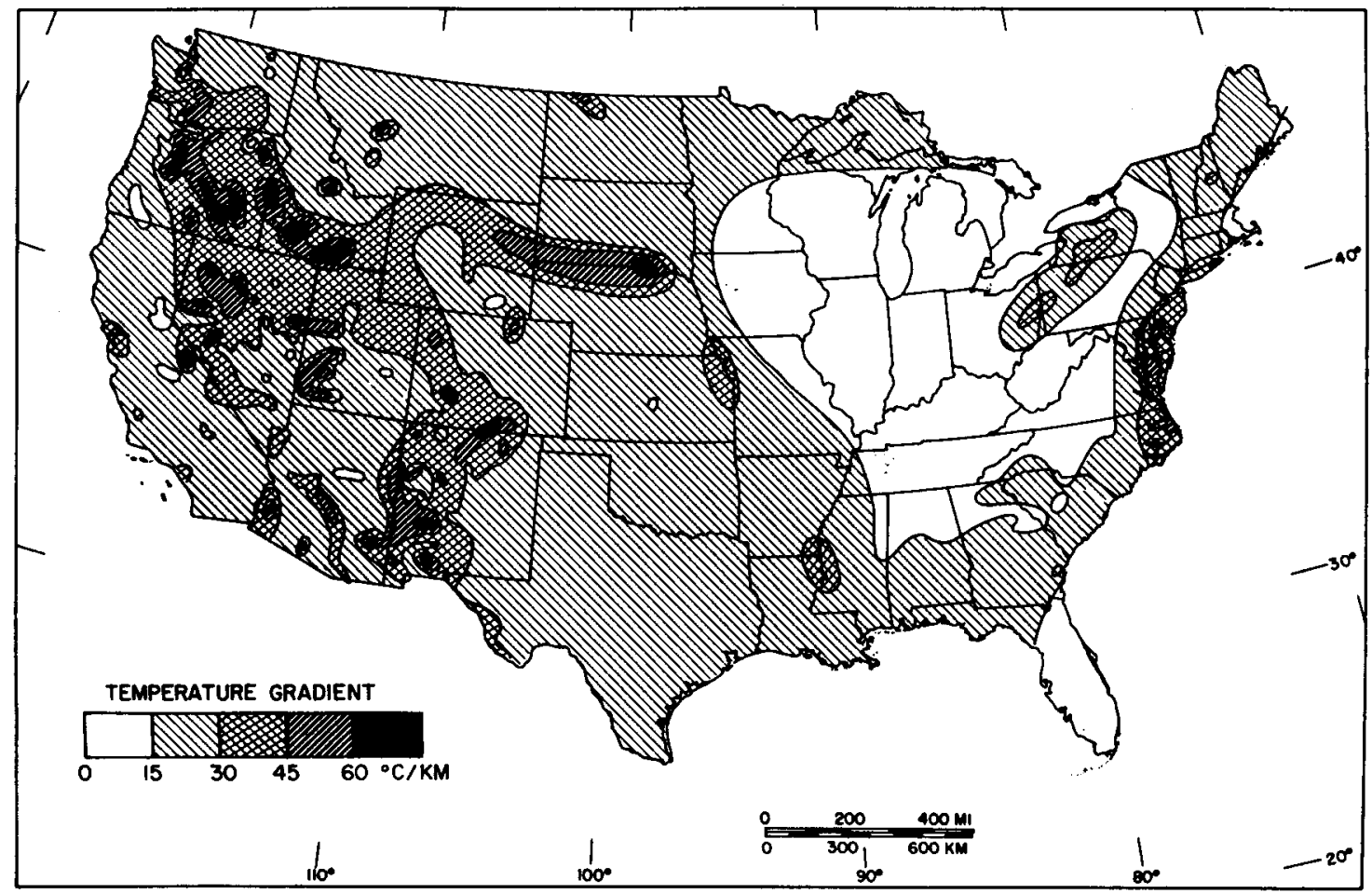

Fig. 46. Geothermal gradient map of the conterminous United States. Data from approximately 900 conductive temperature measurements in wells deeper than $50 \mathrm{~m}$ (modified from Kron and Heiken 1980). 


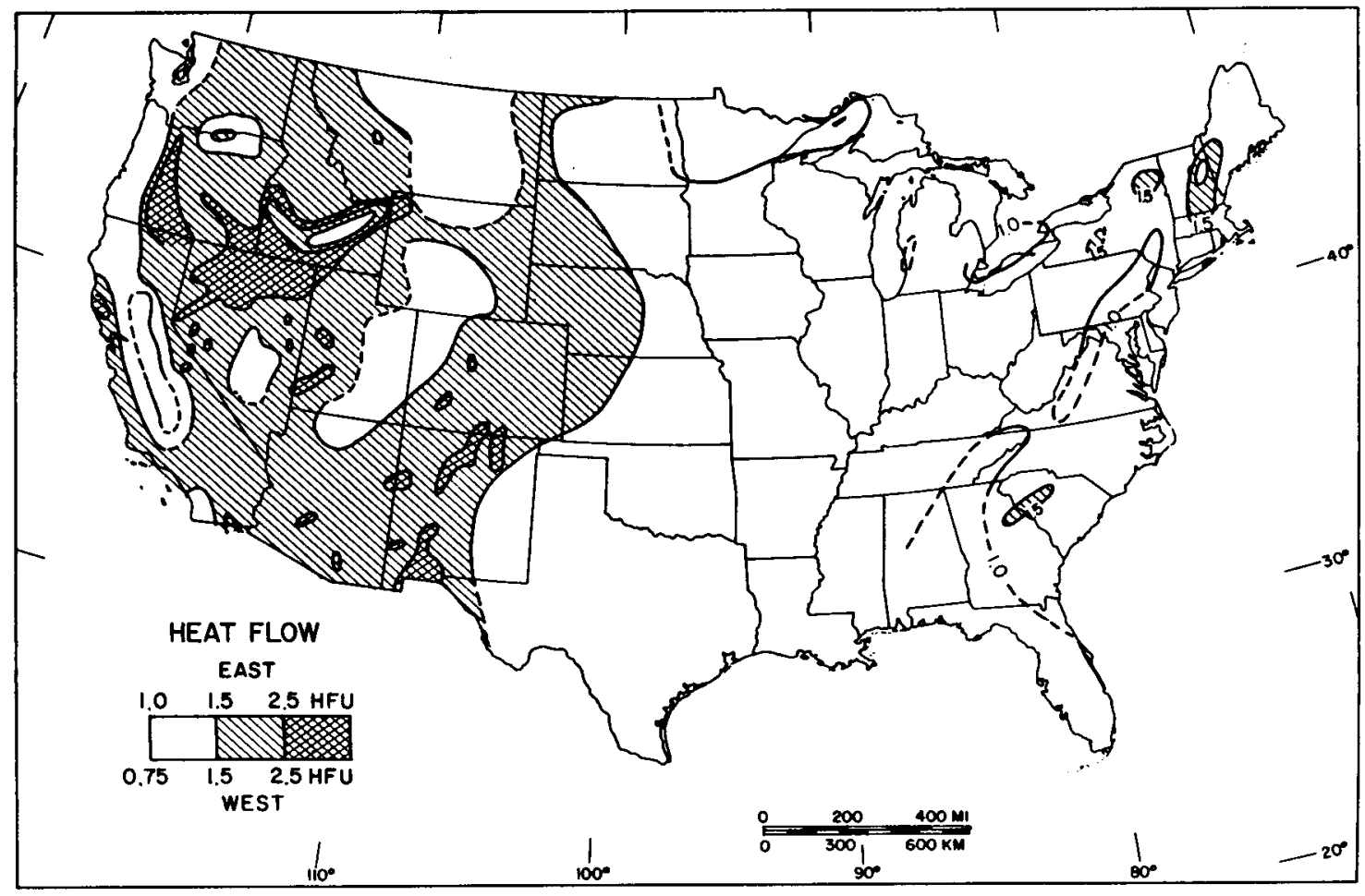

Fig. 47. Heat flow map of the United States (Sass et al.1980).

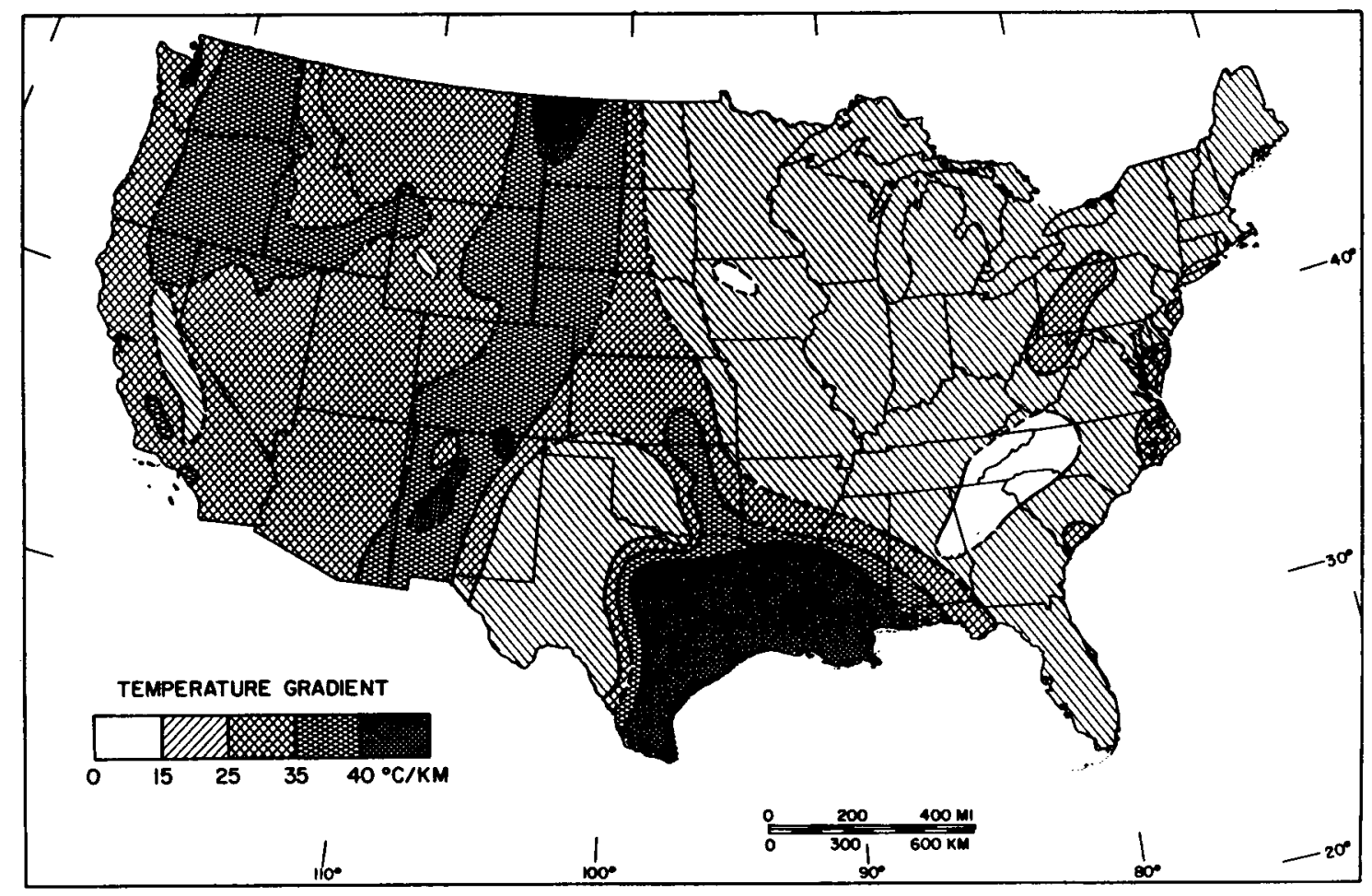

Fig. 48. Preliminary temperature gradient map of the U.S. (Guffanti and Nathenson 1980). 
hydrologic influences (Gosnold 1980). The majority of the midwest and eastern U.S. have gradients less than $30^{\circ} \mathrm{C} / \mathrm{km}$. Exceptions are the Mississippi Embayment where elevated temperatures are associated with the New Madrid Seismic Zone (Swanberg et al. 1978). Also, elevated temperature gradients ranging from 30 to $47^{\circ} \mathrm{C} / \mathrm{km}$ extend along the Atlantic Coast Plain from central New Jersey to east-central North Carolina. Radioactive heat generation from buried 300-Myr plutons is postulated as the anomalous source of heat (Costain et al. 1980). A similar mechanism may explain the anomalous gradients in New York state.

As a resource exploration tool, this map can be used to estimate depth to desired temperatures on a regional basis, to compare with other geological and geophysical information, and to identify areas in the U.S. where adequate geothermal information is lacking. 
A. Evaluation of the High-Grade HDR Resource Base

Igneous systems are relatively small, local anomalies on the order of a few kilometers to tens of kilometers in diameter, but they represent the highest grade geothermal resource available to us. For this reason, we are considering them separately from the overall regional assessment of the HDR geothermal resource of the U.S. A large portion of their heat may be in the form of HDR. The identified hydrothermal systems related to igneous systems generally contain less than $10 \%$ of the total thermal energy of the overall igneous system (Table VII). Brook et al. (1979) estimate that the hydrothermal portions of igneous systems range from only 1.4 to $3.4 \%$.

Admittedly, much of the energy remaining in these systems exists as magma, but preliminary work (Heiken and Goff, unpublished manuscript) indicates that most of it is present as HDR. An estimate of the total thermal energy, to a depth of $10 \mathrm{~km}$, in the 62 young volcanic fields (igneous systems) of the conterminous U.S. is 101000 Quads (Smith and Shaw 1979). Omitting Yellowstone Park, the total is about 65000 Quads. Even if only $50 \%$ of this energy is in the form of HDR (a very conservative estimate), there is a high-grade resource base of 33000 Quads in the young igneous systems of the U.S.

B. Preliminary Regional HDR Resource Base Evaluation

To prove convincingly that HDR is a viable source of direct-use energy nation-wide, we must identify and characterize regions with thermal gradients $>30^{\circ} \mathrm{C} / \mathrm{km}$ because this resource is broadly distributed throughout the United States. Characteristics of potential HDR areas, exploration methods, and potential reservoir rocks are outlined in Table VIII.

Using the 1980 thermal gradient map of the U.S. (Fig. 49) we have estimated the regional geothermal resource base. Total heat contents were determined for regions with gradients of 30,45 , and $60^{\circ} \mathrm{C} / \mathrm{km}$. The heat content was calculated to a depth of $10 \mathrm{~km}$ and for temperatures of $>15^{\circ} \mathrm{C}$ (Table VIII). This includes hydrothermal as well as HDR resources; preliminary regional studies (this publication) indicate that, at depths within these regions where temperatures are adequate for direct use, most of the resource would need to be extracted using HDR techniques. We believe that much of this resource base, at depths of $>3 \mathrm{~km}$, is in the form of HDR. The total HDR regional geothermal 
resource base estimate in the conterminous U.S. is $1504365 \times 10^{18}$ cal or $5.9 \times 10^{6}$ Quads.

The estimated regional geothermal resource base of about $6 \times 10^{6}$ Quads for the conterminous U.S. is considerably smaller than an earlier estimate of $32 \times 10^{6}$ Quads for conductive regimes. That estimate is based on the entire U.S., whereas this estimate is only for regions with thermal gradients of $>30^{\circ} \mathrm{C} / \mathrm{km}$. Measuring heat flow within the U.S. is a big job, which we had hoped to accomplish over the next decade in cooperation with DOE and USGS geothermal program agencies. All data from all programs will eventually be stored in a central data facility at the USGS (Geotherm).

One of the most important considerations in HDR resource evaluation is heat flow. With limited funds for that purpose, we have begun to collect data in large portions of the U.S. where heat-flow data are sparse or absent.

C. Conclusions

Table IX summarizes our 1980 HDR Regional Resource Evaluations and is based on this, our first report on the HDR resource base. As the program proceeds, we will be not only defining resource base, but also aiming toward understanding the nature of the resource and stimulating interest in its development.

\section{ACKNOWLEDGMENTS}

Many people have contributed information for this report; in particular, Jennifer East in her report on Roosevelt Hot Springs, David Gambill in his report on Long Valley, Cassandra Hudson's data reduction, Gerhard Suhr's advice and help in seismic geophysics. Edward Decker and Spencer Shannon of Los Alamos and $W$. Duffield of the USGS were very helpful with their comments on the manuscript. 
TABLE VII

THERMAL ENERGY IN IGNEOUS SYSTEMS, TO $10 \mathrm{KM}$ DEPTHa

(Based on USGS Circulars 726 (1975) and 790 (1979)

\begin{tabular}{|c|c|c|}
\hline Number & System & $\begin{array}{c}\text { A. Thermal } \\
\text { Remaining }\end{array}$ \\
\hline \multirow{2}{*}{\multicolumn{3}{|c|}{$\begin{array}{c}\overline{A 1 \text { aska }} \\
\text { AK4 }\end{array}$}} \\
\hline & Davidof & 29 \\
\hline AK5 & Little Sitkin & 180 \\
\hline & $\begin{array}{l}\text { Semi spochnoi } \\
\text { (Cerberus) }\end{array}$ & 360 \\
\hline AK9 & Tanaga & 960 \\
\hline AK10 & Takawangha & 54 \\
\hline AK12 & Kanaga & 180 \\
\hline AK 14 & Adagdak & 50 \\
\hline AK15 & Great Sitkin & 13 \\
\hline AK22 & Seguam & 480 \\
\hline AK25 & Yunaska & 96 \\
\hline AK34 & Okmak & 603 \\
\hline AK37 & Makushin & 25 \\
\hline AK39 & Akutan & 25 \\
\hline AK 43 & Fisher & 1440 \\
\hline AK51 & Emmons & 1440 \\
\hline AK58 & Veniamnof & 481 \\
\hline AK 59 & Black & 50 \\
\hline AK60 & Aniakchak & 540 \\
\hline \multirow[t]{2}{*}{ AK63 } & Peulik & \\
\hline & (Ugashik Caldera) & 71 \\
\hline AK66 & Novarupta & 120 \\
\hline AK69 & Katmai & 50 \\
\hline AK 75 & Kaguyak & 38 \\
\hline AK84 & Drum & 840 \\
\hline AK86 & Wrangell & 120 \\
\hline AK87 & White River & 190 \\
\hline AK 88 & Edgecumbe & 603 \\
\hline \multicolumn{2}{|c|}{ Sub-Total for Alaska } & 9037 \\
\hline
\end{tabular}

Arizona

AZ21 San Francisco Peaks 3010

Kendrick Peak

Sitgreaves Peak

Bill Williams Mtn.

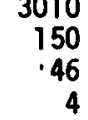

a Based on USGS circulars 726 (1975) and 790 (1979).
B. Hydrothermal

$$
\left(10^{18 \mathrm{j})}\right.
$$

$$
\text { A. }- \text { B. }\left(10^{18 \mathrm{~J})}\right.
$$

HDR Comments

Rock types at depth variable; volc., metam. immature sed.

Very few users near the volc. systems in Alaska.

Estimate for Total Hydrothermal for Igneous

System in Alaska

$$
-580
$$

Tot. Alaska
8457

3010
150
46
4

$\begin{array}{lr}\text { none } & 3010 \\ \text { none? } & 150 \\ \text { none? } & 46 \\ \text { none? } & 4\end{array}$

Hydro. oniy $6.4 \%$ of total

Precambrian basement in Flagstaff area 



\section{TABLE VIII}

\section{HDR REGIONAL RESOURCE EVALUATION}

(Summary 1980)

\begin{tabular}{|c|c|c|c|c|c|}
\hline Region & $\begin{array}{c}\text { Range of } \\
\text { Thermal Gradients } \\
\left({ }^{\circ} \mathrm{C} / \mathrm{km}\right) \\
\end{array}$ & $\begin{array}{c}\text { Potential Reservoir } \\
\text { Rock Units } \\
\end{array}$ & Data Compilations in Progress & $\begin{array}{c}\text { Most Useful } \\
\text { Exploration Techniques }\end{array}$ & $\begin{array}{l}\text { Main Thermal } \\
\text { Sources } \\
\end{array}$ \\
\hline Eastern U.S. & $6-46$ & $\begin{array}{l}\text { Precambrian granitic, } \\
\text { metamorphic terrane }\end{array}$ & $\begin{array}{l}\text { Gravity, aeromag. tectonic, } \\
\text { heat flow, electrical, water } \\
\text { chemistry, geology }\end{array}$ & Heat flow, gravity & $\begin{array}{l}\text { Heat generation in } \\
K, U \text {, Th-rich } \\
\text { granitic plutons }\end{array}$ \\
\hline Midcontinent U.S. & $8-55$ & $\begin{array}{l}\text { Precambrian granitic, } \\
\text { metamorphic terrane }\end{array}$ & $\begin{array}{l}\text { Gravity, aeromag., tectonic, } \\
\text { water chemistry, heat flow, } \\
\text { MT, seismic, geology }\end{array}$ & Heat flow, gravity, MT & $\begin{array}{l}\text { Heat generation in } \\
K, U, \text { Th-rich } \\
\text { granitic plutons }\end{array}$ \\
\hline Rocky Mountain & $16->100$ & $\begin{array}{l}\text { Precambrian granitic } \\
\text { and metamorphic ter- } \\
\text { rane, cemented sedi- } \\
\text { ments, volcanic rocks } \\
\text { (very complex) }\end{array}$ & $\begin{array}{l}\text { Geology (volcanology), heat } \\
\text { flow, gravity, water chemis- } \\
\text { try, MT, sei smic, aeromag., } \\
\text { tectonic }\end{array}$ & $\begin{array}{l}\text { Vol canology, heat flow, } \\
\text { tectonic, MT, gravity } \\
\text { aeromag. }\end{array}$ & $\begin{array}{l}\text { Heat generation in } \\
K, U, \text { Th-rich } \\
\text { granitic plutons, } \\
\text { crustal thinning, } \\
\text { magma }\end{array}$ \\
\hline Southwes tern U.S. & $14-84$ & $\begin{array}{l}\text { Precambrian and } \\
\text { younger, granitic and } \\
\text { metamorphic terrane, } \\
\text { metamorphosed volcanic } \\
\text { rocks }\end{array}$ & $\begin{array}{l}\text { Gravity, aeromag., tectonic, } \\
\text { volcanology, water chemistry, } \\
\text { MT, seismic }\end{array}$ & $\begin{array}{l}\text { Volcanology, heat flow, } \\
\text { MT, gravity }\end{array}$ & $\begin{array}{l}\text { Crustal thinning, } \\
\text { magma }\end{array}$ \\
\hline Far Western U.S. & $6->100$ & $\begin{array}{l}\text { Granitic and meta- } \\
\text { morphic terrane } \\
\text { (variety of ages), } \\
\text { tightly cemented } \\
\text { sediments, greenstone }\end{array}$ & $\begin{array}{l}\text { Tectonic, volcanology, heat } \\
\text { flow, MT, gravity, aeromag., } \\
\text { water chemistry }\end{array}$ & $\begin{array}{l}\text { Volcanology, heat flow, } \\
\text { water chemistry }\end{array}$ & $\begin{array}{l}\text { Magma, crusta thin- } \\
\text { ning }\end{array}$ \\
\hline Northwestern U.S. & $8->100$ & $\begin{array}{l}\text { Granitic and meta- } \\
\text { morphic terrane } \\
\text { (variety of ages), } \\
\text { cemented volcani- } \\
\text { clastic rocks, thick } \\
\text { basalt flows (?) }\end{array}$ & $\begin{array}{l}\text { Tectonic, vol canology, heat } \\
\text { flow, gravity, aeromag., } \\
\text { water chemistry }\end{array}$ & Heat flow, volcanology & $\begin{array}{l}\text { Crustal thinning, } \\
\text { magma }\end{array}$ \\
\hline
\end{tabular}


TABLE IX

REGIONAL GEOTHERMAL RESOURCE BASE TO $10 \mathrm{KM}\left(>15^{\circ} \mathrm{C}\right)$

Total Area of

Gradients Thermal Anomalies Heat Content (1018 cal)

\begin{tabular}{cc} 
Area & $i \mathrm{c} / \mathrm{k}$ \\
\hline & \\
Eastern U.S. & 30 \\
Eastern U.S. & 45 \\
Western U.S. & 30 \\
Western U.S. & 45 \\
Western U.S. & 60 \\
Totals &
\end{tabular}

$\left(\mathrm{km}^{2}\right)$

$0-3 \mathrm{~km}$

$3-10 \mathrm{~km}$

$0-10 \mathrm{~km}$

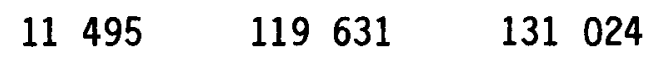

$\begin{array}{llll}682 & 7161 & 7844\end{array}$

5832

$\begin{array}{llllll}81 & 539 & 848 & 549 & 929 & 363\end{array}$

1036080

$315567 \quad 345 \quad 634$

256977

30066

82127

90500

$\begin{array}{llllllll}132 & 155 & 1 & 373 & 035 & 1 & 504 & 365\end{array}$

= 5972329 Quads $5.9 \times 10^{6}$ Quads 
REFERENCES

A'dam, A., 1978, Geothermal effects in the formation of electrically conducting zones and temperature distribution in the earth: Phys. Earth Plan. Int., 17: pp. 21-28.

Aiken, C. L. V., and M. E. Ander, 1980, A regional strategy for geothermal exploration with emphasis on gravity and magnetotellurics: J. Volc. and Geotherm. Res., 9, pp. 1-27.

Allen, J. E., 1951, The Carrizozo malpais, in Roswell Geol. Soc. Guidebook: 5 th Field Conf. Carrizozo-Capitan-Chapadera Mesa region, Lincoln and Socorro Counties, NM, pp. 9-11.

Aoki, Ken-Ichiro, 1976, Petrography and petrochemistry of latest Pliocene olivine-tholeiites of Taos area, northern New Mexico, USA, Contr. Mineralogy and Petrology, v. 14, pp. 191-203.

Aoki, Ken-Ichiro, and A. M. Kudo, 1978, Major-element variations of late Cenozoic basalts of New Mexico, in Cenozoic Volcanism in Southwestern New Mexico, W. E. Elston and S. A. Northrop (eds.), New Mexico Geol. Soc. Spec. Paper No. 5, pp. 82-88.

Arney, B. H., J. B. Beyer, D. B. Simon, F. B. Tonani, R. B. Weiss, 1980, 1980 Hot dry rock geothermal site evaluation, W. Snake River Plain, Idaho: GRC Transactions 4, pp 197-200.

Aubele, J. C., 1978, Geology of Cerros del Rio volcanic field, Guidebook to Rio Grande rift in New Mexico and Colorado: New Mexico Bur. of Mines and Mineral Resources, Circ. 163, pp. 198-201.

Baars, D. L., 1976, The Colorado Plateau aulocogen--key to continental scale basement rifting, in M. H. Podwysocki and J. L. Earle (eds.), Basement Tectonics, Proc. 2nd Intern. Conf, pp. 157-164.

Bachman, G. 0., 1953, Geology of a part of northwestern Mora County, New Mexico, US Geol. Survey 0il and Gas Inv., OM 137.

Bachman, G. 0., R. F. Marvin, H. H. Mehnert, and V. Merritt, 1975, K-Ar ages of the basalt flows at Los Lunas and Albuquerque, central New Mexico, I sochron/West, no. 13, pp. 3-4.

Bachman, G. 0., and H. H. Mehnert, 1978, New K-Ar dates and the late Pliocene to Holocene geomorphic history of the central Rio Grande region, New Mexico, Geol. Soc. of Amer. Bul1 ., v. 89, pp. 283-292.

Bailey, E. H., W. P. Irwin, and D. L. Jones, 1964, Franciscan and related rocks, and their significance in the geology of western California, Calif. Div. of Mines and Geol. Bu11. 183. 
Bailey, R. A., G. B. Dalrymple, and M. A. Lanphere, 1976, Volcanism and geochronology of long valley caldera, Mono County, California, J. Geophys. Res. 81, pp. 725-744.

Baldwin, B., and W. R. Muehlberger, 1959, Geologic studies of Union County, New Mexico: New Mexico Bur. of Mines and Mineral Resources Bull. 63, p. 171 .

Bassett, W. A., P. F. Kerr, 0. A. Schaeffer, and R. W. Stoenner, 1963, Potassium-argon ages of volcanic rocks near Grants, New Mexico: Geol. Soc. Am. Bul1., v. 74, no. 2, pp. 221-225.

Bechtel National, Inc., 1980, Map of the United States showing generalized areas for HDR resources, in unpublished report an industrial assessment of the feasibility of HDR geothermal systems.

Berry, G. W., P. J. Grim, J. A. Ikelman, 1980, Thermal Springs 1ist for the United States, NOAA key to geophysical records documentation no. 12 , p. 59 .

Biehler, S., and W. E. Bonini, 1968, A regional gravity study of the Boulder Batholith, Montana, in Igneous and Metamorphic Geology, GSA Mem. 115, pp. 401-422.

Blackwe11, D. D., 1969, Heat-Flow Determinations in the Northwestern United States, JGR 74, pp. 992-1007.

Blackwe11, D. D., 1974, Terrestrial heat flow and its implications on the location of geothermal reservoirs in Washington, in Energy resources of Washington, (Washington) information circular no. 50, pp. 21-33.

Blackwe11, D. D., 1978, Heat flow and energy loss in the western U.S., 1978, in Cenozoic tectonics and regional geophysics of the western cordillera, $R$. B. Smith and G. P. Eaton (ed.), GSA Mem. 152, pp. 175-208.

Blackwel1, D. D. and J. L. Steele, 1979, Regional heat flow in the Northern Cascade Range of Oregon, in geothermal resource assessment of Mt. Hood, U.S. Dept. of Energy RLO-1040-T1, ed. D. A. Hu11, pp. 225-264.

Blackwe11, D. D., D. A. Hul1, R. G. Bowen, J. L. Steele, 1978, Heat flow of Oregon, Oregon special paper, pp. 4, 42, and map.

Bodvarsson, G., and G. M. Reistad, 1975, Econometric analysis of forced geoheat recovery for low-temperature uses in the Pacific Northwest; in U.N. Symp. on Develop. and Use of Geothermal Res. pp. 1559-1564.

Bonham, H. F., 1969, Geology and mineral deposits of Washoe and Storey Counties, Nevada, $1969 \mathrm{Nev}$. Bur. of Mines and Geol. Bul1. 70, 140 pp.

Braile, L. W., and R. B. Smith, 1979, The structure of the crust in the Yellowstone-Snake River Plain area and adjacent provinces and implications for crustal evolution, Abs., EOS 60, p. 941. 
Braile, L. W., R. B. Smith, J. Ansorge, M. R. Baker, C. Prodehl, J. H. Healy, St. Mueller, K. H. 0lsen, K. Priestly, and J. Brune, 1979, The YellowstoneSnake River Plain seismic profiling experiment, Abs., EOS 60, p. 941.

Brinkworth, G. L. and M. D. Kleinkopf, 1972, Bouguer gravity in Geologic Atlas of the Rocky Mountain Region. W. W. Mallory, ed., pp. 45-47.

Brook, C. A., R. H. Mariner, D. R. Mabey, J. R. Swanson, M. Guffanti, and L. J. P. Muffler, 1979, Hydrothermal convection systems with reservoir temperatures $>90^{\circ} \mathrm{C}$, in L. J. P. Muffler, ed., Assessment of Geothermal Resources of the United States--1978, U.S. Geol. Surv. Circ. 790, pp. 18-85.

Brott, C. A., D. D. Blackwell, J. C. Mitchell, 1978, Tectonic implications of the heat flow of the western Snake River Plain, Idaho, GSA Bul1. 89, pp. 1697-1707.

Bufe, C. G. and F. W. Lester, 1975, Seismicity of The Geysers-Clear Lake Region, California," EOS, Trans. Am. Geophys. Union 56, no. 12.

Burchfiel, B. C., J.E. 01iver, and L. T. Silver, co-chairmen, 1980, Panel on Continental Tectonics, Continental Tectonics, Nat. Acad. of Sci. Studies in Geophy. Series, $197 \mathrm{pp}$.

Byerly, P. E., and R. H. Stolt, 1977, An attempt to define the Curie point isotherm in northern and central Arizona, Geophys., v. 42, pp. 1394-1400.

Chapin, C. E., R. M. Chamberlin, G. R. Osburn, D. W. White, A. R. Sanford, 1978, Exploration framework of the Socorro geothermal area, New Mexico, in New Mexico Geol. Soc. Spec. Publ. no. 7, Field Guide to Selected Cauldrons and Mining Districts of the Datil-Mogollon Volvanic Field, New Mexico, C. E. Chapin and W. E. Elson (eds.).

Chapman, R. H., 1975, Geophysical study of the Clear Lake Region, California, Calif. Div. Mines and Geol., Spec. Rep. 116.

Collins, R. F., 1949, Volcanic rocks of northeastern New Mexico, Geol. Soc. America But1., v. 60, pp. 1017-1040.

Costain, J. K., L. Glover III, and A. K. Sinha, 1980, Low temperature geothermal resources in the Eastern United States, EOS, 61, 1-3.

Costain, J. K., L. Glover III, and A. K. Sinha, 1979, Evaluation and targeting of geothermal energy resources in the Southeastern United States, progress report October 1, 1978 - March 30, 1979, Virginia Polytechnic Institute and State University, B1acksburg, VA, VPISU-5648-5.

Damon, P. E., 1965, Correlation and chronology of ore deposits and volcanic rocks, U.S. Atomic Energy Comm. Prog. Rept., C00-689-50, p. 60.

Damon, P. E., 1966, Correlation and chronology of ore deposits and volcanic rocks: U.S. Atomic Energy Comm. Ann. Prog. Rept., C00-689-6Q, 46 pp. 
Damon, P. E., A. W. Laughlin, and J. K. Percious, 1967, The problem of excess argon-40 in volcanic rocks: radioactive dating and methods of low-level counting, Internat. Atomic Energy Agency, Vienna, pp. 463-481.

Damon, P. E., Muhammad Shafiqullah, and J. S. Leventhal, 1974, K-Ar chronology for the San Francisco volcanic field and rate of erosion of the Little Colorado River, in Geol. Soc. Am., Rocky Mt. Sec. Mtg., Flagstaff, AZ, 1974,

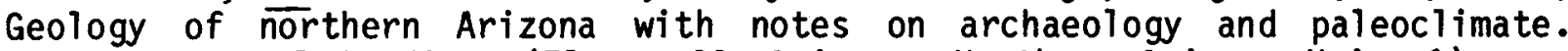
Part I Regional Studies, (Flagstaff, Arizona, Northern Arizona Univ. 1), pp. 221-235.

Deal, E. G., W. E. Elston, E. E. Erb, S. L. Peterson, D. E. Reiter, P. E. Damon, and Muhammad Shafiqullah, 1978, Mid-Tertiary magmatism in southeastern Arizona, J. F. Callendar, J. C. Wilt, and R. E. Clemmons (eds.), New Mexico Geol. Soc. Guidebook, 29th Field Conf., Land of Cochise, pp. 219-230.

deBoer, J., 1980, Paleomagnetism of the quaternary Cerro Prieto, Crater Elegante, and Salton Buttes Volcanic Domes in the northern part of the Gulf of California Rhombochasm," Proc. of 2nd Symp. on the Cerro Prieto Geothermal Field, Baja California, Mexico, Lawrence Berkeley Laboratory report LBL-9546.

Diment, W. H., T. C. Urban, J. H. Sass, B. V. Marshal1, R. J. Munroe, and A. H. Lachenbruch, 1975, Temperatures and heat contents based on conductive transport of heat, in Assessment of Geothermal Resources of the United States, D. J. White and D. W. Williams, eds., and U.S. Geol. Surv. Cir. 726, pp. 84-103.

Doell, R. R., and G. B. Dalrymple, R. L. Smith, and R. A. Bailey, 1968, Paleomagnetism, potassium-argon ages and geology of rhyolites and associated rocks of the Valles Caldera, New Mexico, Geol. Soc. America Mem. 116, pp. 211-248.

Donnelly, J. M., 1977, Geochronology and evolution of the Clear Lake Volcanic Field, Ph.D. Thesis, University of California, Berkeley.

Donnelly, J. M., R. J. McLaughlin, F. E. Goff, and B. C. Hearn, Jr., 1980, Active faulting in the Geysers-Clear Lake Area, Northern California, Geol. Soc. Am. Abst. with Programs 8, no. 3, pp. 369-370.

East, J. S., 1981, Hot dry rock geothermal potential of Roosevelt Hot Springs Area: Review of data and recommendations, LOS Alamos National Laboratory report LA-8751-HDR.

Eberly, L. D., and T. B. Stanley, Jr., 1978, Cenozoic stratigraphy and geologic history of southwestern Arizona, Geol. Soc. Am. Bul1., v. 89, pp. 921-940.

Edwards, C. L., M. Reiter, C. Shearer, and W. Young, 1978, Terrestrial heat flow and crustal radioactivity in northeastern New Mexico and southeastern Colorado, Geol. Soc. Am. Bul1., v. 89, pp. 1341-1350. 
Elders, W. A., 1979, The geological background of the geothermal fields of the Salton Trough, in Geology and Geothermics of the Salton Trough, Guidebook, Field Trip no. 7, W. A. Elders, Ed., Geol. Soc. Amer. 92nd Ann. Meeting, San Diego, California.

Euge, K. M., W. R. Lund, and J. D. Scott, 1978, Geology of the Palo Verde Nuclear Generating Station and adjacent areas, Maricopa County, Arizona, Arizona Bureau of Geology and Mineral Technology Special Pub. 2, pp. 115-129.

Fenneman, N. M., 1946, Physical divisions of the United States, map prepared in cooperation with the Physiographic Committee, U.S. Geol. Surv.

Gambi11, D., 1981, Hot dry rock geothermal potential of Long Valley Caldera, California," Los Alamos National Laboratory report LA-8710-HDR.

Gamble, T. D., W. M. Goubeau, and J. Clarke, 1979a, Magnetotellurics with remote reference, Geophysics, v. 44, pp. 53-68.

Gamble, T. D., W. M. Goubeau, and J. Clarke, 1979b, Error analysis for remote reference magnetotellurics: Geophysics, v. 44: pp. 959-968.

Geotronics Corporation, 1979, Non-exclusive magnetotelluric data. Austin, Texas.

Glenn, W. E., J. B. Helen, and D. L. Nielson, 1981, A comprehensive study of Los Alamos National Laboratory well C/T-2, Roosevelt Hot Springs KGRA, Utah, and applications to geothermal well logging," Los Alamos National Laboratory informal report LA-8686-MS.

Goff, F. E., J. M. Donnelly, J. M. Thompson, and B. C. Hearn, Jr., 1977, Geothermal Prospecting in The Geysers-Clear lake Area, Northern California, Geol. 5 no. $8,509-515$ (1977).

Goff, F., 1980, Geology of the Geysers-Clear Lake Geothermal Regime, Northern California," in Continental Scientific Drilling Program Thermal Regimes, $F$. Goff and A. C. Waters, Eds., Los Alamos Scientific Laboratory report LA-8550-OBES 7-28.

Goff, F. E., 1979, "Wet" geothermal potential of the Kingman-Williams region, Arizona, Los Alamos National Laboratory report, LA-7757-MS, p 25. with map.

Goff, F. E., B. H. Arney, C. L. Aiken, F. G. West, and A. C. Eddy, 1979, Pre1 iminary evaluation of the Aquarius Mountains hot dry rock geothermal prospect, Arizona, Geotherm. Res. Council, Trans., v. 3, pp. 257-260.

Goff, F. and A. C. Waters, 1980, Continental scientific drilling program thermal regimes: Geology of five magma-hydrothermal systems, LoS A1 amos Scientific Laboratory report LA-8550-OBES.

Gosnold, W. D., 1980, Preliminary report on the geothermal resource potential of Nebraska, Geotherm. Res. Coun., Trans., v. 4, pp. 45-48. 
Guffanti, M., and M. Nathenson, 1980, Preliminary map of temperature gradients in the conterminous United States, Geotherm. Res. Coun., Trans., v. 4, pp. $53-56$.

Gutmann, J. T., C. L. Aiken, M. E. Ander, and R. T. Laney, 1980, Preliminary geological and geophysical evaluation of the Castle Dome HDR geothermal prospect, southwestern Arizona, Geotherm. Res. Coun., Trans., v. 4, pp. 205-207.

Gutmann, J. T., 1981, Geologic framework and hot dry rock geothermal potential of the Castle Dome Area, Yuma County, Arizona, Los Alamos National Laboratory report LA-8723-HDR.

Hearn, B. C., Jr., J. M. Donnelly, and F. E. Goff, 1976a, Prel iminary geologic map and cross-section of the Clear Lake Volcanic Field, Lake County, California, U.S. Geol. Surv. Open-file Report 76-751.

Hearn, B. C., Jr., J. M. Donnelly, and F. E. Goff, 1976b, Geology and geochronology of the Clear Lake Volcanics, California," Proc. 2nd U.N. Symp. Dev. and Use of Geother. Res., May 20-29, 1975 (Lawrence Berkeley Laboratory) Vol. 1, pp. 423-428.

Hearn, B. C., Jr., J. M. Donnelly, and F. E. Goff, 1981, The Clear Lake Volcanics, California: Tectonic setting and magma sources," U.S. Geol. Surv. Prof. Paper.

Hermance, J. F., 1979, Toward assessing the geothermal potential of the Jemez mountains volcanic complex: a magnetotelluric survey, Los Alamos National Laboratory report LA-7656-MS.

Hill, D. P., 1963, Gravity and crustal structure in the W. Snake River Plain, I daho, JGR 68, pp. 5807-5819.

Hill, D. P., 1972, Crustal and Upper Mantle Structure of the Colorado Plateau from Range Seismic Refraction Measurements, GSA Bu11. V. 83, pp. 1639-1648.

Hill, D. P., 1976, Structure of Long Valley Caldera, California, from a seismic Refraction Experiment," J. Geophys. Res. 81, pp. 745-753.

Hoffer, J. M., 1976, The Potrillo basalt field, south-central New Mexico, in Cenozoic volcanism in southwestern New Mexico, W. E. Elston and S. A. Northrop (eds.), New Mexico Geol. Soc. Spec. Pub. no. 5, pp 89-92.

Hot Dry Rock Assessment Panel (HDRAP), 1977, Hot dry rock geothermal energy: status of exploration and assessment, ERDA Report 77-74, $206 \mathrm{pp}$.

Hot Dry Rock Program Plan, 1980, Dept. of Energy, Div. Geol. Energy, HDR-P01, October 1980, $41 \mathrm{pp}$.

Hsu, K. J., 1968, Principles of melanges and their bearing on the FranciscanKnoxville Paradox," Geol. Soc. of Am. Bul1. 79, no. 8, 1063-1074. 
Hussey, K. M., 1971, A K-Ar date on the Rocky Mountain pediment sequence, north-central New Mexico, I sochron/West, no. 2, p. 45.

Hyndman, D. W., 1979, Major tectonic elements and tectonic problems along the line of section from northeastern Oregon to west-central Montana, GSA Map and Chart Series, MC-28C.

Isherwood, W. F., 1976, Gravity and magnetic studies of the Geysers-Clear Lake Geothermal Region, California, Proc. 2nd U.N. Symp. on the Dev. and Use of Geotherm. Res., Vol. 2, pp. 1065-1073.

Iyer, H. M. and T. Hitchcock, 1975, Teleseismic residuals at the Geysers Geothermal Area, EOS. Trans. of the Am. Geophys. Union 56, no. 12, (1975) p. 1020.

Jennings, C. W., 1977, Geologic map of California, California Division of Mines and Geology Geologic Data Map no. 2, 1:750,000.

Jiracek, G. R., M. E. Ander, and H. T. Holcome, 1979, Magnetotelluric soundings of crustal conductive zones in major continental rifts, in Rio Grande Rift: Tectonics and magmatism, R. E. Riecker (ed.), Am. Geophys. Union, pp. 209-222.

Jupp, D. L. B., and K. Vozoff, 1977, Two-dimensional magnetotelluric inversion, Geophys. J. R. Astr. Soc., v. 50, pp. 333-352.

Johnson, S. H., and R. W. Couch, 1970, Crustal structure in the North Cascade Mountains of Washington and B.C. from seismic refraction measurements, Bull. Seismological Soc. Am. 60, pp. 1259-1269.

Kane, M. F., D. R. Mabey, and R. L. Brace, 1976, A gravity and magnetic investigation of the Long Valley Caldera, Mono County, California, $J$. Geophys. Res. 81, 754-762.

Kron, A. and G. Heiken, 1980, Geothermal gradient map of the conterminous United States, Los Alamos National Laboratory map, LA-8476-MAP, scale 1:5000 000; GRC Trans. 4, pp. 69-71.

Lachenbruch, A. H., M. L. Sorey, R. E. Lewis, and J. H. Sass, 1976, The nearsurface hydrothermal regime of Long Valley Caldera, J. of Geophys. Res. 81, no. 5, 763-768.

Lachenbruch, A. H. and J. H. Sass, 1980, Heat flow and energetics of the San Andreas Fault Zone, Jour. of Geophys. Res. 85, pp. 6185-6222.

LaFehr, T. R., and L. C. Pakiser, 1962, Gravity, volcanism, and crustal deformation in the eastern Snake River Plain, Idaho, US Geol. Soc. Prof. Paper 450-D, D76-D78.

Laughlin, A. W., 1981, The geothermal system of the Jemez. Mountains, New Mexico (USA), in Geothermal systems--principles and case histories, L. Rybach and R. J. P. Muffler (eds.), John Wiley and Sons. 
Laughlin, A. W., and F. G. West, 1976, The Zuni Mountains, New Mexico, as a potential hot dry rock geothermal energy site, U.S. Energy Research and Development Admin., Los Alamos Scientific Laboratory Report LA-6197-MS, p. 13.

Laughlin, A. W., D. G. Brookins, P. E. Damon, and Muhammad Shafiqullah, 1979, Late Cenozoic volcanism of the central Jemez zone, Arizona-New Mexico, I sochron/West No. 25 , pp. 5-8.

Laughlin, A. W., P. E. Damon, and Muhammad Shafiqullah, in press, New K-Ar dates from the Springerville volcanic field, central Jemez zone, Apache County, Arizona, Isochron/West.

Lee, G. K., and J. Bell, 1975, Late Cenozoic geology along the Gila River near Gillespie Dam, central Arizona (Abs.), Geol. Soc. Am. Abs. with Programs, v 7, no. 3, pp. 340-341.

Lee, W. T., 1922, Description of the Raton, Brilliant, and Koehler quadrangles, U.S. Geol. Surv. Atlas, Folio 214.

Lidiak, E. G., 1972, Precambrian rocks in the subsurface of Nebraska, Nebraska Geol. Sur. Bu11., no. 26.

Lipman, P. W., 1969, Alkalic and tholelitic basaltic volcanism related to the Rio Grande depression, southern Colorado and northern New Mexico, Geol. Soc. Ame. Bul1 ., v. 80, pp. 1343-1353.

Lipman, P. W., and H. W. Mehnert, 1975, Late Cenozoic basaltic volcanism and development of the Rio Grande depression in the Southern Rocky Mountains, Geo1. Soc. Am. Mem. 144, pp. 119-154.

Lipman, P. W., and H. W. Mehnert, 1979, The Taos plateau volcanic field, northern Rio Grande rift, New Mexico, R. E. Riecker (ed.), in Rio Grande rift: Tectonics and Magmatism, Am. Geophys. Union, Washington DC, pp. 289-312.

Luedke, R. G., and R. L. Smith, 1978, Map showing distribution, composition, and age of late Cenozoic volcanic centers in Arizona and New Mexico: U.S. Geo1. Surv. Map, no. I-1091-A.

Luedke, R. G., and R. L. Smith, 1978a, Map showing distribution, composition, and Age of Late Cenozoic Volcanic Centers in Colorado, Utah, and Southwestern Wyoming, U.S. Geological Survey Map I-1091-B, 1:1,000,000.

Lynch, D. J., 1978, The San Bernardino volcanic field of southeastern Arizona, J. F. Callender, J. C. Wilt, and R. E. Clemmons (eds)., New Mexico Geol. Soc. Guidebook, 29th Field Conf., Land of Cochise, pp. 261-268.

Mabey, D. R., 1976, Interpretation of a gravity profile across the western Snake River Plain, Idaho, Geology $\underline{4}$, pp. 53-55. 
Mabey, D. R., 1978a, Geophysics of the Snake River Plain, Abs. in 1978 International Symposium on the Rio Grande Rift, 54, Publ. Los Alamos Scientific Laboratory Conference, LA-7487-C.

Mabey, D. R., 1978b, Rebional gravity and magnetic anomelies in the Eastern Snake River Plain, ASGS J. Research 6, pp. 553-562.

Mabey, D. R., I. Zietz, G. P. Eaton, M. D. Kleinkopf, 1978, Regional magnetic, patterns in part of the cordillera in the Western U.S., GSA Mem. 152, pp. 93-106.

MacLeod, N. S., G. W. Walker, and E. H. McKee, 1976, Geothermal significance of eastward increase in age of upper Cenozoic Rhyolitic domes in southeastern Oregon, Proceedings, 2nd UN Symposium on the Development and Use of Geothermal Resources, pp. 465-474.

Malde, H. E., 1959, Fault zone along northern boundary of western Snake River Plain, Idaho, Science, 130, p. 272.

Malde, H. E., H. A. Powers, and C. H. Marchall, 1963, Reconnaissance geologic map of west-central Snake River Plain, U.S. Geol. Soc. Map, no. 1-373.

Mallory, W. W., M. R. Mudge, V. E. Swanson, D. S. Stone, and W. E. Lumb, eds., 1972, Geologic Atlas of the Rocky Mountain Region, United States of America, Rocky Mountain Assoc. of Geologists, 331 pp.

Manley, Kim, 1978, Cenozoic geology of Espanola basin, Guidebook to Rio Grande rift in New Mexico and Colorado: New Mexico Bureau of Mines and Mineral Resources Circ., 163, pp. 201-210.

Mariner, R. H. and L. M. Willey, 1976, Geochemistry of thermal waters in Long Valley, Mono County, California, J. Geophys. Res. 81, pp. 792-800.

Marvin, R. F., C. W. Naeser, and H. H. Mehnert, 1978, Tabulation of radiometric ages--including $K-A r$ and fission-track ages--for rocks in southeastern Arizona and southwestern New Mexico, New Mexico Geol. Soc. Guidebook, 29th Field Conf., pp. 243-252.

Marvin, R. F., and S. W. Dobson, 1979, Radiometric ages: Compilation B, U.S. Geol. Surv., I sochron/West, no. 26, pp. 3-27.

Mase, C. W., J. H. Sass, and A. H. Lachenbruch, 1980a, Preliminary heat-flow investigation of the California Cascades, Abs., EOS, 61, p. 1150.

Mase, C. W., J.H. Sass, and A. H. Lachenbruch, 1980, Near-surface hydrotherma 1 regime of the Lassen "Known geothermal resources area," California, USGS open-file report $80-1230$.

Maxwe11, J. C., 1974, Early western margin of the U.S., in The Geology of Continental Margins, C. A. Burk and C. L. Drake (eds.), $\overline{p p}$. 831-852 (SpringerVerlag, New York). 
Mayo, E. B., 1958, Lineament tectonics and some ore districts of the southwest: AIME Trans., pp. 1169-1175.

Mckee, E. H., R. L. Smith, and H. R. Shaw, 1974, Preliminary geothermal exploration, San Francisco volcanic field northern Arizona (Abs.), Geol. Soc. Am. Abs. with Programs, v. 6, no. 5, p. 458.

McLaughlin, R. J. and W. D. Stanley, 1976, Pre-tertiary geology and structural control of geothermal resrouces, the Geysers Steam Field, California, Proc. of 2nd U.N. Symp. on the Dev. and Use of Geotherm. Res., Vol . 1, pp. 475-486.

Moore, James G., 1969, Geology and mineral deposits of Lyon, Douglas, and Ormsby Counties, Nevada, New Bur. of Mines and Geol. Bul1. 75, p. 45.

Merril1, R. K., and T. L. Pewe, 1977, Late Cenozoic geology of the White Mountains, Arizona, State of Arizona, Bureau of Geology and Mineral Technology, Univ. of Ariz., Spec. Paper, no. 1, p. 65.

Muffler, L. J. P., and D. E. White, 1969, Active metamorphism of upper Cenozoic sediments in the Salton Sea Geothermal Field and the Salton Trough, Southeastern California," Geol. Soc. Am. Bu11. 80, pp. 157-182.

Muffler, L. J. P. (ed.) 1979, Assessment of geothermal resources of the United States--1978, U.S. Geo1. Surv. Circ., 790, p. 163.

Nichols, R. L., 1946, McCarty's basalt flow, Valencia County, New Mexico, Geol. Soc. Am. Bul1., v. 57, no. 11, pp. 1049-1086.

Nielson, D. L., B. S. Sibbett, D. B. Mckinney, J. B. Hulen, J. N. Moore, and S. M. Samberg, 1978, Geology of Roosevelt Hot Springs KGRA, Beaver County, Utah," Utah Res. Inst., Earth Science Laboratory report no. 12, Salt Lake City, Utah, p. 121.

01 sen, K. H., P. A. Johnson, J. N. Stewart, and E. F. Homuth, 1980, Synthetic seismogram modeling of refraction profiles and crustal structure in the eastern Snake River Plain, Idaho, GSA Abs., 12, no. 6, p. 300.

Osberg, P. H., R. Wettevauer, M. Rivers, W. A. Bothner, and J. W. Creasy, 1978, Feasibility study of the Conway Granite as a geothermal energy resource, U.S.D.0.E. Tech. Info. Center, Oak Ridge, TN, Tech. report C00-2686-1.

Ozima, M., M. Kono, I. Kaneoka, H. Kinoshita, N. T. Kobayashi, E. E. Larson, and D. W. Strangway, 1967, Paleomagnetism and potassium-argon ages of some volcanic rocks from the Rio Grande gorge in New Mexico, J. Geophys. Res., v. 72 , no. 10 , pp. 2615-2621.

Pakiser, L. C., 1963, Structure of the crust and upper mantle in the western U.S., J. Geophys. Res., 68, pp. 5747-5756. 
Parry, W. T., J. M. Ballantyne, N. L. Bryant, and R. E. Dedolph, 1980, Geochemistry of hydrothermal alteration of the Roosevelt Hot Springs Thermal Area, Utah," Geochim. Cosmochim. Acta. 44, 95-102.

Penta Cruz, I., L. A. de la Pena, 1979, Geology of the Cerro Prieta Field, in Proc. of the First Symp. on the Cerro Prieto Field, Baja California, Mexico, Lawrence Berk ley Laboratory report LBL-7098.

Petrick, W. R., W. H. Pelton, S. H. Ward, 1977, Ridge regression inversion applied to crustal resistivity sounding data from South Africa, Geophy., v. 42, no. 5, pp. 995-1005.

Pollack, H. N., and D. S. Chapman, 1977a, Mantle heat flow: earth plan, Sci. Lett., 34, p. 174-194.

Pollack, H. N., and D. S. Chapman, 1977b, On the regional variation of heat flow, geotherms, and lithospheric thickness, Tectonophysics, 38, pp. 279-296.

Porath, H., 1971, A review of the evidence on low-resistivity layers in the earth's crust. in The Structure and Physical Properties of the Earth's Crust, J. G. Heacock (ed.), Am. Geophys. Union Mon., 14, pp. 127-144.

Prodeh1, C., 1979, Crustal structure of the Western United States, U.S. Geological Survey Prof. Paper 1034, 74 pp.

Reiter, Marshal1, C. L. Edwards, Harold Hartman, Charles Weidman, 1975, Terrestrial heat flow along the Rio Grande rift, New Mexico, and southern Colorado, Geo1. Soc. Am. Bul1., v. 86, pp. 811-818.

Reiter, M., A. J. Mansure, and C. Shearer, 1979a, Geothermal characteristics of the Colorado Plateau, in T. R. McGetchin and R. B. Merrill, eds., Plateau Uplift: Mode and Mechanism, Tectonophysics 61, pp. 183-195.

Reiter, M., A. J. Mansure, and C. Shearer, 1979b, Geothermal characteristics of the Rio Grande Rift within the Southern Rocky Mountain Complex, in R. E. Reicker, ed., Rio Grande Rift: Tectonics and Magmatism, AGU, pp. 253-267.

Rember, W. C., and E. H. Bennett, 1979, Geologic map of the Hailey Quadrangle, Idaho, Idaho Bur. of Mines and Geology.

Renault, Jacques, 1970, Major-element variations in the Potrillo, Carrizozo, and McCartys basalt fields, New Mexico, New Mexico Bur. Mines and Min. Res. Circ., 22, pp. 113 .

Roberts, R. J., K. M. Montgomery and R. E. Lehner, 1967, Geology and mineral resources of Eureka County, Nevada, Nev. Bur. of Mines Bu11. 64, 152 pp.

Robertson, E. S., R. 0. Fournier, and C. P. Strong, 1975, Hydrothermal activity in southwestern Montana, in Proc. 2nd U.N. Symp. on the Devel. and Use of Geothermal Resources, Vo. 1, pp. 553-561. 
Robinson, R. and H. M. Iyer, 1979, Evidence from teleseismic P-wave observations for a low velocity body under the Roosevelt Hot Springs Geothermal Area, Utah," Geotherm. Res. Coun. Trans. 3, 585 pp.

Roy, R. F., D. D. Blackwell, and F. Birch, 1968, Heat generation of plutonic rocks and continental heat flow provinces, EPSL, $\underline{5}$, pp. 1-12.

Roy, R. F., D. D. Blackwell, and E. R. Decker, 1972, Continental heat flow, in The Nature of the Solid Earth, E. C. Robertson (ed.), McGraw-Hill, pp. 506-543.

Sanford, A. R., R. P. Mott, Jr., P. J. Shuleski, E. J. Rinehart, F. J. Caravella, R. M. Ward, and T. C. Wallace, 1977, Geophysical evidence for a magma body in the crust in the vincinity of Socorro, New Mexico, in The Earth's Crust, J. G. Heacock (ed.), Geophysical Monograph 20, pp. 385-403.

Sass, J. H., D. D. Blackwe11, D. S. Chapman, J. K. Costain, E. R. Decker, L. A. Lawver, and C. A. Swanberg, 1980, Heat flow from the crust of the U.S., in Physical Properties of Rocks and Minerals, Y. S. Touloukian, W. R. Judd, and R. F. Roy (eds.), McGraw-Hi11, (in press).

Schubert, C. E., J. C. Maxwell and W. J. Johnson, 1980, The eastern hot dry rock target prospect - a case history, Geotherm. Res. Coun. Tran., v. 4, pp. 241-244.

Shearer, C. R., 1979, A regional terrestrial heat flow study in Arizona, Ph.D. dissertation, New Mexico Institute and Technology, Socorro, p. 184.

Shafiqullah, Muhammad, P. E. Damon, D. J. Lynch, S. J. Reynolds, W. A. Rehrig, and R. H. Raymond, 1980, K-Ar geochronology and geologic history of southwestern Arizona and adjacent areas, Arizona Geol. Soc. Digest, v. XII, pp. 201-260.

Shoustra, J. J., J. L. Smith, J. D. Smith, R. L. Strand, and D. Duff, 1976, Geology and seismicity, site lithologic conditions, and Appendix $2 Q$ (radiometric age), in Palo Verde Nuclear Generating Stations 1, 2, and 3, Preliminary Safety Analysis Report, Arizona Public Service Commission, v. 2, pp. 2.5-60 and 2.5-75, and v. 8, Appendix 20 .

Silberman, M. L. and E. H. McKee, 1972, A summary of radiometric age determinations on tertiary volcanic rocks from Nevada and Eastern California: Part II, Western Nevada, I sochron/West 4, pp. 7-28.

Smith, J. L. and Rex, R. W., 1977, Drilling results from the Eastern Long Valley Caldera in American Nuclear Society, energy and mineral resource recovery, U.S. Dept. of Energy CONF-770440, pp. 529-540.

Smith, R. B. and M. Sbar, 1974, Contemporary tectonics and seismicity of the western states with emphasis on the Intermountain Seismic Belt," Geol. Soc. Am. Bu11. 85, pp. 1205-1218. 
Smith, R. B., 1978, Seismicity, crustal structure and intraplate tectonics of the interior of the western cordillera, in Cenozoic Tectonics and Regional Geophysics of the Western Cordillera, R. B. Smith and G. P. Eaton (eds.), Geo1. Soc. Am., Mem. 152, pp. 111-144.

Smith, R. L., and R. A. Bailey, 1968, Resurgent cauldrons, Geol. Soc. Am., Mem. 116, pp. 613-662.

Smith, R. L., R. A. Bailey, and C. S. Ross, 1970, Geologic map of the Jemez Mountains, New Mexico, US Geol. Surv., Map I-571.

Smith, R. L., and H. R. Shaw, 1979, Igneous-related geothermal systems, in Assessment of Geothermal Resources of the United States, D. F. White and D. L. Williams ed., U.S. Geol. Surv., Cir. 726, pp. 58-83. L. J. P. Muffler, ed., U.S. Geol. Surv., Cir. 790, pp. 12-17.

Spence, W., R. S. Gross, and L. H. Jacksha, 1979, P-wave velocity stucture beneath the central Rio Grande rift, Abstract, AGU Tran., v. 60, no. 46.

Steeples, D. W. and H. M. Iyer, 1976, Low-velocity zone under Long Valley as determined from teleseismic events," J. Geophys. Res. 81, pp. 849-860.

Steeples, D. W. and M. E. Bickford, 1980, An effort to recover Precambrian rock material by deepening two boreholes in Kansas, (unpub. report to the Los Alamos Sci. Lab., August 29, 1980).

Stewart, J. H., and J. E. Carlson, 1976, Cenozoic rocks of Nevada - four maps and brief description of distribution, lithology, age, and centers of volcanism, Nevada Bureau of Mines and Geology Map 52, 1:1,000,000.

Stewart, J. H., 1978, Basin-range structure in western North America: a review, in Cenozoic Tectonics and Regional Geophysics of the Western Cordiliera, R. B. Smith and G. P. Eaton (eds.), Geol. Soc. Am. Mem., 152, pp. 1-31.

Stormer, J. C., Jr., 1972a, Ages and nature of volcanic activity on the southern high plains, New Mexico and Colorado, Geol. Soc. Am. Bull., v. 83, no. 8, pp. 2443-2448.

Stormer, J. C., Jr., 1972b, Mineralogy and petrology of the Raton-Clayton volcanic field, northeastern New Mexico, Geol. Soc. Am. Bull., v. 83, p. 32993322 .

Swanberg, C. A., P. Morgan, C. H. Stoyer, and J. C. Witcher, 1977, An appraisal study of the geothermal resources of Arizona and adjacent areas in New Mexico and Utah and their value for resalination and other cases, New Mexico Energy Report, 006, Las Cruces, New Mexico.

Swanberg, C. A., and P. Morgan, 1978, The linear relation between temperatures based on the silica content of groundwater and regional heat flow: a new heat flow map of the United States, PA Geophysics, v. 117, pp. 227-241. 
Swanberg, C. A., B. J. Mitche11, R. L., Hohse, and D. D. B1ackwe11, 1978, Heat flow in the upper Mississippi embayment, submitted to US Geological Survey Special Paper on the New Madrid Seismic zone.

Tewhey, J. D., 1977, Geologic Characteristics of a Portion of the Salton Sea Geothermal Field," Lawrence Livermore Laboratory report UCRL-52267.

Thiruvathukal, J. V., J. W. Berg, Jr., and D. F. Heinrichs, 1970, Regional gravity of Oregon, GSA Bul1. 81, pp. 725-738.

Thompson, J. M., 1979, A Reevaluation of Geothermal Potential of the Wilbur Hot Springs Area, Cali fornia," Geotherm. Res. Coun. Trans. 3, pp. 729-731.

Tilling, R. I., 1973, Boulder Batholith, Montana: a product of two contemporaneous but chemically distinct magma series. Geol. Soc. Am. 84, pp. 3879-3900.

Tweto, 0., 1979, The Rio Grande Rift system in Colorado, in R. W. Reicker, ed., Rio Grande Rift: Tectonics and Magmatism, Am. Geolphys. Union, pp. 33-56.

United States Geological Survey and The American Association of Petroleum Geologists, 1962, Tectonic Map of the United States, $1: 2,500,000$.

United States Geological Survey, 1978, Aeromagnetic Map of Idaho, Geophysical Investigations Series Map GP-919.

Vaniman, D., B. Crowe, and E. S. Gladney, 1980, GEology and petrology of the basalts of Crater Flat: applications to volcanic risk assessment for the Nevada nuclear waste storage investigations. Los Alamos National Laboratory report LA-8845-MS.

Van Schmuss, W. R., and M. E. Bickford, in press, Proterozoic chronology and evolution of the midcontinent region, North America, in Precambrian Plate Tectonics, A. Kroner (ed.), Elsevier.

von Frese, R. R. B., W. J. Hinze, L. W. Braile, 1980, Gravity and magnetic anomaly modeling of Mississippi embayment crustal structure at satellite elevations, in An integrated geophysical and geological study of the tectonic framework of the 38th parallel lineament in the vicinity of its intersection with the extension of the New Madrid Fault Zone, Annual Progress Report--Fiscal Year 1980, to the Division of Reactor Safety Research, US Nuclear Regulatory Commission, Contract no. NRC-04-323.

Ward, S. H., W. T. Parry, W. P. Nash, W. R. Sill, K. L. Cook, R. B. Smith, D. S. Chapman, F. H. Brown, J. A. Whelan, and J. R. Bowman, 1978, A summary of the geology, geochemistry, and geophysics of the Roosevelt Hot Springs Thermal Area, Utah," Geophys. 43, pp. 1515-1542.

Waring, G. A, 1915, Springs of California, U.S. Geological Survey Water Supply Paper 338. 
Warner, L. A., 1978, The Colorado lineament: a middle Precambrian wrench fault system, Geo1. Soc. of Am. Bu11., v. 89, pp. 161-171.

Washington Public Power Supply System, 1978, Aeromagnetic data from WNP 2 final safety analysis report, Chap, 2,5 , as amended.

West, F. G., and A. W. Laughlin, 1979, Aquarius Mountain area, Arizona: a possible HDR prospect, Geothermal Energy, 7, pp. 13-20; Los Alamos Scientific Laboratory report LA-7804-MS, 16 pp.

Whipple, R. W., 1979, A Comparison of Petroleum Information well data with areas considered generally favorable for the recovery of thermal waters, unpublished.

White, D. E., I. Barnes, and J. R. O'Neil, 1973, Thermal and mineral waters of nonmeteoric origin, California Coast Ranges," Geo1. Soc. of Am. Bu11. 84, no. 2, pp. 547-560.

White, D. E., and D. L. Williams, eds., 1975, Assessment of geothermal resources of the United States - 1975, USGS Circ. 726, 155 pp.

White, D. E. and C. E. Roberson, 1962, Sulphur Bank, California, a major Hot Spring Quicksilver Deposit, in Petrologic Studies-A Volume in Honor of A. F. Buddington, New York, Geol. Soc. of Am. pp. 397-428.

Willden, R., 1964, Geology and mineral deposits of Himiboldt County, Nevada, Nevada Bur. of Mines and Geol. Bu11. 59, $154 \mathrm{p}$.

Willden, R., and R. C. Speed, 1974, Geology and mineral deposits of Churchill Co., Nevada," Nevada Bureau of Mines and Geology, Bu11. 83 (1974), 95 p.

Wollenberg, H., S. Vander Haar, and N. Crow, 1980, The geologic setting of the Salton Trough," in Continental Scientific Drilling Program Thermal Regimes: Comparitive Site Assessment Geology of Five Magma-Hydrothermal Systems, $F$. Goff and A. C. Waters, Eds. Los Alamos Scientific Laboratory report LA-8550OBES (1980).

Woollard, G. P., 1966, Regional isostatic relations in the United States, in The Earth Beneath the Continents: A Volume of Geophysical Studies, J. S. Steinhart and T. J. Smith, eds., pp. 557-594.

Zoback, M. D., R. M. Hamilton, A. J. Crone, D. P. Russ, F. A. Mckeown, and S. R. Brockman, 1980, Recurrent intraplate tectonism in the New Madrid seismic zone, Science, v. 209, no. 4460, pp. 971-976. 